Portland State University

PDXScholar

\title{
Soil Properties and Behavior of Earthflows in the Mt. Hood National Forest, Oregon
}

Douglas Andrew Smith

Portland State University

Follow this and additional works at: https://pdxscholar.library.pdx.edu/open_access_etds

Part of the Geography Commons

Let us know how access to this document benefits you.

\section{Recommended Citation}

Smith, Douglas Andrew, "Soil Properties and Behavior of Earthflows in the Mt. Hood National Forest, Oregon" (1994). Dissertations and Theses. Paper 4779.

https://doi.org/10.15760/etd.6663

This Thesis is brought to you for free and open access. It has been accepted for inclusion in Dissertations and Theses by an authorized administrator of PDXScholar. Please contact us if we can make this document more accessible: pdxscholar@pdx.edu. 


\section{THESIS APPROVAL}

The abstract and thesis of Douglas Andrew Smith for the Master of Science in Geography were presented April 19, 1994, and accepted by the committee and the department.

COMMITTEE APPROVALS:

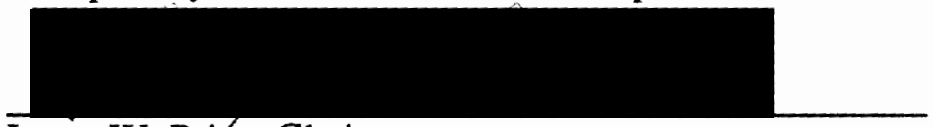

Larry W. Price, Chair

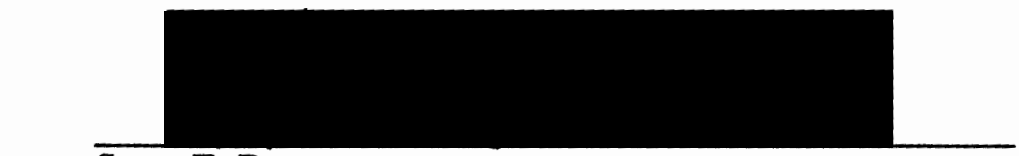

Scott F. Burns
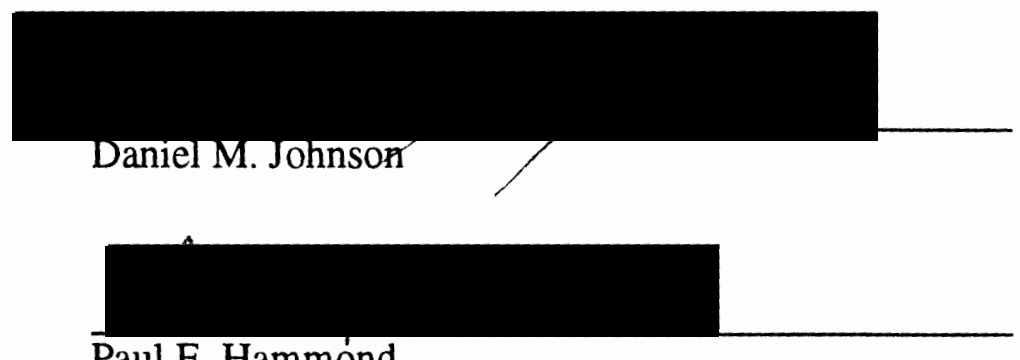

Paul E. Hammond

Representative of the Office of Graduate Studies

DEPARTMENT APPROVAL:

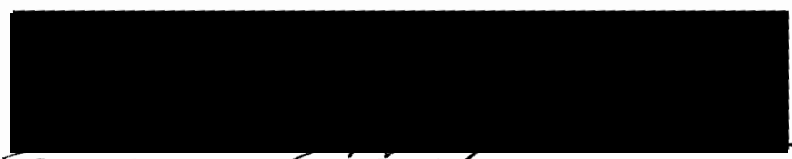

Daniel M. Johnson, Chair

Department of Geography

\section{ACCEPTED FOR PORTLAND STATE UNIVERSITY BY THE LIBRARY}

by on

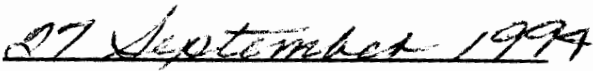




\begin{abstract}
An abstract of the thesis of Douglas Andrew Smith for the Master of Science in Geography presented May 19, 1994.
\end{abstract}

Title: Soil Properties and Behavior of Earthflows in the Mt. Hood National Forest, Oregon

Soils from two active earthflows, two earthflow deposits, and three non-earthflow landforms are examined to determine if a connection exists between near-surface soil properties and rates of earthflow movement. The study area is located in the Clackamas Ranger District of the Mt. Hood National Forest in the northern Oregon Cascades. Its geology consists of clay-bearing volcaniclastic formations overlain by unaltered flows of andesite and basalt, a combination that contributed to large-scale landsliding during the late Pleistocene. Deposits from these landslides now cover much of the valley floor, and it is from these deposits that earthflows tend to mobilize.

The main hypothesis is that near-surface soil properties reflect earthflow movement and may be used to distinguish between active and inactive earthflows. The results support this hypothesis and indicate that soils in each of the three categories show clear differences in terms of their physical properties. The mean field moisture content of active earthflows is 56 percent, while that of earthflow deposits is 46 percent and that of non-earthflow landforms is 36 percent. All samples from active earthflows exhibit plasticity, whereas 90 percent of samples from earthflow deposits and only 25 percent of samples from nonearthflow landforms exhibit plasticity. The mean liquid limit of active earthflows is 78 percent, compared to 60 percent for earthflow deposits and 46 percent for non-earthflow 
landforms. The mean plasticity index of active earthflows is 41 percent, compared to only 13 percent for earthflow deposits and non-earthflow landforms. These differences are largely attributed to clay content and clay type. The mean clay content of active earthflows is 46 percent, compared to 24 percent for earthflow deposits and only 5 percent for nonearthflow landforms. In contrast, the mean sand content of active earthflows is 20 percent, while earthflow deposits contain 40 percent and non-earthflow landforms 50 percent. This difference in particle sizes is reflected in friction angle. Active earthflows have a mean friction angle of 15 degrees, compared to 24 degrees for earthflow deposits and 31 degrees for non-earthflow landforms.

These results indicate that soil properties can be used to draw distinctions between active and inactive earthflows. However, soil properties are much less effective at distinguishing between active earthflows that move at different rates. For example, Junction earthflow, which moves only a few centimeters per year, is composed of soils that indicate it to be less stable than the Collowash earthflow, which moves approximately 2 meters per year. The reason for this discrepancy is that, in addition to soil properties, the rate of earthflow movement depends on the complimentary effects of hydrology, slope angle, toe erosion, and boundary roughness.

Many ancient landslide deposits in the Mt. Hood National Forest are poised for action and may mobilize upon the slightest provocation. Since this is not seen as a "desired future condition" there is a need to differentiate between those deposits with a potential for reactivation and those likely to remain dormant. Examining the physical properties of soils appears to be one way to do this, and the information collected is valuable to land managers and earth scientists alike. 
SOIL PROPERTIES AND BEHAVIOR OF EARTHFLOWS IN THE MT. HOOD NATIONAL FOREST, OREGON

by

DOUGLAS ANDREW SMITH

A thesis submitted in partial fulfillment of the requirements for the degree of

\section{MASTER OF SCIENCE \\ in \\ GEOGRAPHY}

Portland State University

1994 


\section{ACKNOWLEDGEMENTS}

While completing this research I have been fortunate to have the guidance and assistance of many friends and organizations. Without their help, this thesis would have been substantially less.

I would like to thank my advisor, Dr. Larry Price, for his patient reviews of early drafts and for his insightful advice on many subjects. I am thankful to Dr. Scott Burns for his enthusiasm and bounty of suggestions. Thanks also to Dr. Dan Johnson and Dr. Paul Hammond for their editorial comments, and to Carolyn Perry for her generous and invaluable help throughout this project.

I am indebted the geotechnical group at the Mt. Hood National Forest for supporting me as a volunteer and employee. Thanks especially to Ginnie Grilley and Chris Gross for their intensity, their imagination, and hours of good discussion. Thanks to Cliff Denning and Rob Piehl for ably and patiently fielding one geotechnical question after another. Most of all, thanks to Tom DeRoo, whose knowledge of geology, sense of humor, clear thoughts, and friendship made this a truly memorable experience.

I also wish to thank Tom Koler of the Intermountain Research Station for his input and guidance, and Chris Phillips of Landscare Research in New Zealand for accompanying me in the field and sharing his knowledge of earthflows.

I am grateful to my family for the unconditional support they have provided from the outset of this work. Their encouragement has seen me through difficult times.

Finally, many thanks to Daneen for her kindness and perspective, and for always making me see there is something more, even when I think I see it all. 


\section{TABLE OF CONTENTS}

PAGE

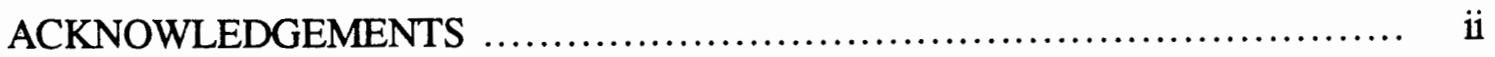

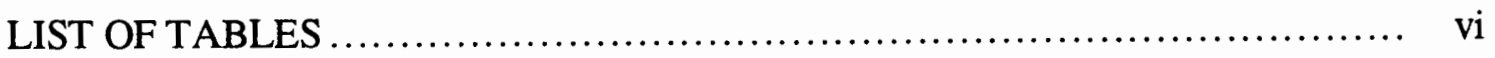

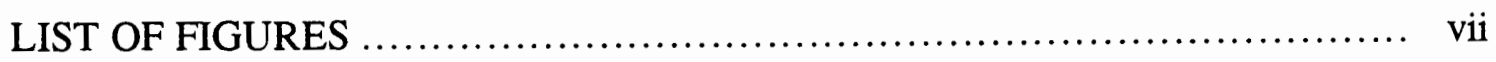

CHAPTER

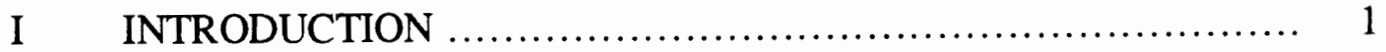

II $\quad$ AREAL SETTING ............................................. 4

Geographic Location .................................. 4

Physiography ......................................... 4

Geology ............................................ 9

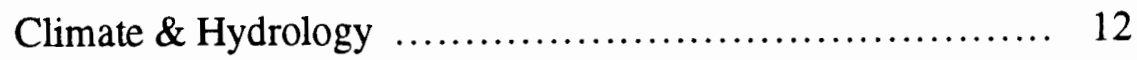

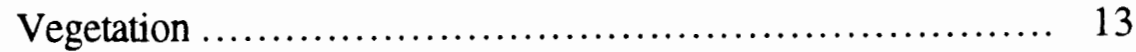

Soils.................................................... 14

III LITERATURE REVIEW OF EARTHFLOWS .................... 16

Background ............................................ 16

Definition ............................................. 18

Classification .......................................... 24

Identification ......................................... 26

Movement …............................................ 26

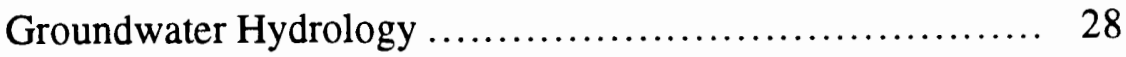

Timber Harvest .......................................... 30 
IV METHODOLOGY................................................ 34

$\mathrm{V} \quad$ DESCRIPTION OF STUDY SITES ............................ 39

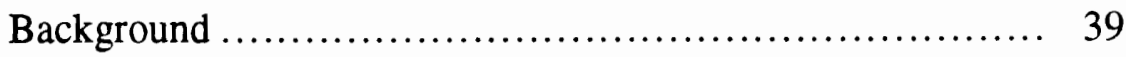

Junction Earthflow ................................... 39

Morphology

Monitoring \& Movement

Thixotropy

Collowash Earthflow........................................... 48

Morphology

Monitoring \& Movement

Alder Earthflow Deposit .................................. 61

Morphology

Monitoring \& Movement

Happy Creek Earthflow Deposit

Morphology

Monitoring \& Movement

Non-Earthflow Landforms ................................ 67

Basalt

Glacial Till

Alluvial Terrace Deposits

VI RESULTS \& DISCUSSION ................................... 69

Major Influences on Earthflow Activity .................... 69

Strength Characteristics

Slope Angle

Toe Erosion

Landform Shape

Soil Properties

Atterberg Limits

Field Moisture

Particle Sizes

Strength Characteristics

Correlations 86

Atterberg Limits

Field Moisture

Particle Sizes 


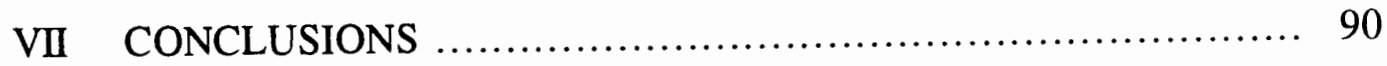

Future Work .................................... 92

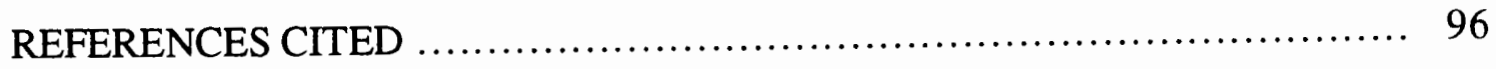

APPENDICES

A SOIL PROPERTIES FOR EACH SAMPLE ..................... 109

B MEAN SOIL PROPERTIES FOR EACH LANDFORM ............. 119

C CORRELATION MATRIX FOR EACH LANDFORM.............. 125 


\section{LIST OF TABLES}

TABLE

PAGE

I Mean Values for Soil Samples from all Landform Types ............... 76

II Correlation Matrix of Soil Properties and Site Characteristics for all Samples 86 


\section{LIST OF FIGURES}

\section{FIGURE}

PAGE

1. Mt. Hood National Forest Location Map ........................... 5

2. Earthflow Distribution within the Mt. Hood National Forest ........... 6

3. Oblique Aerial View of Road 46 Earthflow Complex ................... 8

4. Stratigraphic Sequence of Geologic Formations in the Study Area ...... 10

5. Mass-Wasting Classification ..................................... 17

6. Idealized Earthflow ............................................. 19

7. Debris Flow Channel f............................................ 20

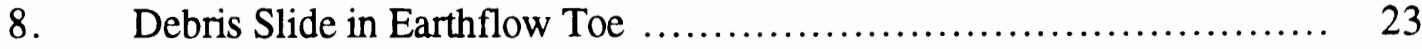

9. Shallow Root Network of Douglas Fir on Earthflow Terrain .......... 31

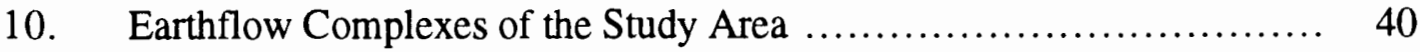

11. Road 46 Earthflow Complex .................................... 41

12. Soil Piping at Junction Earthflow................................ 43

13. Exposed Toe of Junction Earthflow ............................. 45

14. Typical Junction Earthflow Soil Profile........................... 46

15. Mottled Soil from Junction Earthflow ............................. 46

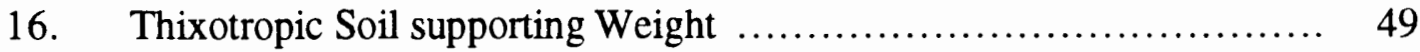

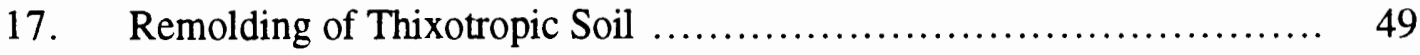

18. Thixotropic Soil in Remolded State ............................ 50

19. Thixotropic Response to Disturbance ............................ 51 
20. Collowash Earthflow Complex ................................. 52

21. Collowash Earthflow Complex ................................ 54

22. Secondary Earthflow Toe ................................... 55

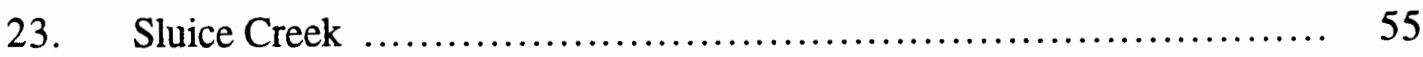

24. Boundary Shear Zone ...................................... 56

25. Stretched Roots ............................................... 58

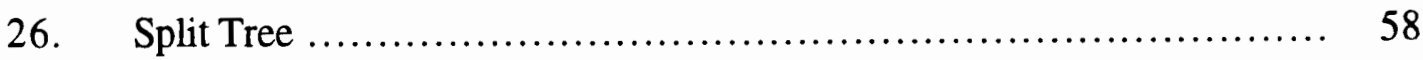

27. Slope Failure in the Toe of the Collowash Earthflow .................. 59

28. Debris Slide at the Toe of Alder Earthflow Deposit .................. 62

29. Happy Creek Earthflow Deposit ............................... 66

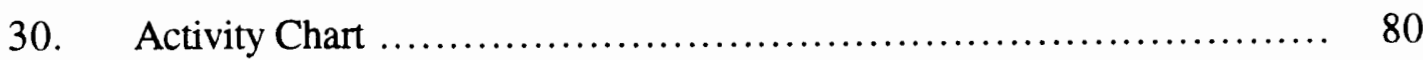

31. Soil Particle Sizes ................................................ 81

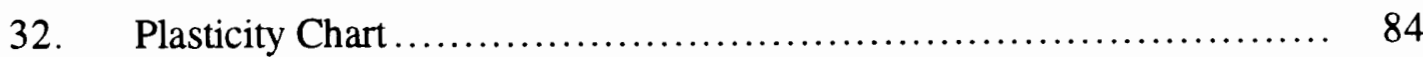

33. Earthflow Risk to Management .................................. 94 


\section{CHAPTER I}

\section{INTRODUCTION}

An earthflow may be defined as a large mass of cohesive soil and regolith that slides, flows, and rotates within discrete boundary shear zones (Keefer and Johnson 1983; Bovis 1986; Iverson 1986a; Zhang et al. 1991a). Earthflows are best identified by their morphology, which typically includes multiple scarps and associated tension cracks, lateral deposits, pressure ridges, hummocky terrain, tilted or "jack-strawed" trees, and a single lobe marking the earthflow's farthest advance. In the Pacific Northwest, earthflows occur on moderately sloping terrain in areas of copious precipitation, clay-bearing rock formations, and deep, cohesive soils. Because the conditions that govern earthflow behavior are seldom constant, the interaction of earthflows with other elements of the ecosystem is often highly complex. Consequently, although earthflows are widely recognized as an important geomorphic agent, they remain somewhat unpredictable and are therefore difficult to manage.

In the Mt. Hood National Forest, earthflows have received increased attention in recent years because of their assumed response to timber harvesting and their role in the degradation of salmon spawning habitat. For millennia, earthflows have delivered prodigious amounts of sediment to fish-bearing streams with little appreciable effect on the salmon's ability to survive and prosper. However, recent speculations have associated increased earthflow activity with logging and have implicated earthflows with contributing to steadily declining salmon runs (USFS 1981; FEMAT 1993, 1994).

Pursuant to the National Forest Management Act (1976), which was created to help ensure proper management of forest land, the Mt. Hood National Forest implemented a 
Forest Land and Resource Management Plan (USFS 1990a). Because of the regional importance of earthflows, one section of this Forest Plan established guidelines for management activities on high- and moderate-risk earthflow terrain. Although their intent was commendable, some of these guidelines were flawed in their lack of scientific basis. Moreover, the method by which earthflows were assigned to a risk category was somewhat arbitrary and inconsistent. Consequently, some landforms that are known to be stable have been designated as earthflow terrain and are therefore managed in an unnecessarily conservative fashion. Before revisions to the Forest Plan can be made, however, more accurate information about earthflow properties and behavior is needed.

The central concern in managing earthflows is over their largely unknown response to timber harvesting. Trees make two key contributions to slope stability: they provide root strength and, through evapotranspiration, they remove water from the soil. Root strength is relatively unimportant to deep-seated stability because the roots seldom penetrate the failure surface. Decreased evapotranspiration, however, is thought to be very important because it may reduce soil strength by increasing pore-water pressure along potential or preexisting failure surfaces. Although much of the timber on "earthflow terrain" has already been harvested, more harvesting is planned. The belated apprehension is that earthflows which are effectively stable under present conditions may reactivate or accelerate following timber harvest. Indeed, perhaps this has already occurred, but since the rates and extent of earthflow activity prior to timbering are unknown, the effects of past timber harvests on current earthflow activity cannot be ascertained. Since many earthflows in the region are currently dormant or moving imperceptibly, reactivation or small accelerations may go unnoticed. However, because they move persistently on an annual or seasonal basis, increases in movement rates, however slight, may have a significant impact on the sediment influx to streams and rivers. 
This study attempts to relate the physical properties of earthflow soils to patterns of earthflow activity in the Clackamas Ranger District of the Mt. Hood National Forest, Oregon. The principal objective is to evaluate earthflow terrain so that dormant or potential earthflows can be recognized and protected from land management impacts. This is accomplished by examining and comparing the soil properties of two active earthflows, two earthflow deposits, and three landforms unrelated to earthflow activity, all of which are located within the upper Clackamas River watershed. The main hypothesis is that nearsurface soil properties reflect earthflow movement and may be used to distinguish between active and inactive earthflows. To test the hypothesis, field moisture contents, Atterberg limits, particle sizes, bulk density, and shear strength were determined for soil samples taken from the landform types mentioned above. The data obtained from these tests and data from previous work were used to infer clay mineralogy and estimate friction angles. 


\section{CHAPTER II}

\section{AREAL SETTING}

\section{GEOGRAPHIC LOCATION}

The study area is located within the boundaries of the Mt. Hood National Forest in the Western Cascades province of northern Oregon (Figure 1). Over 90 percent of the Mt. Hood's earthflow terrain occurs within the Clackamas and Estacada Ranger Districts (Figure 2). Earthflows in the Clackamas Ranger District were chosen for study because they have been monitored in the past, they tend to be more accessible, and they display a wider range of movement rates than those found elsewhere.

\section{PHYSIOGRAPHY}

The study area is broadly mapped as Quaternary landslide and debris flow deposits with Tertiary intrusions (Walker and MacLeod 1991). In an early geological mapping of the region, the study area was left unmapped because these landslide deposits concealed the formations (Barnes and Butler 1930). In a more recent and detailed map, individual landslide complexes were delineated adjacent to the Upper Clackamas River and many of its tributaries (Hammond et al. 1982). The landslides tend to form where unaltered flows of Pliocene age basalt and andesite overlie clay-rich tuffaceous rocks of Miocene age (Dyrness 1967; Swanson and James 1975; Orr et al. 1992). The highly-jointed overlying rock rapidly transmits water to the underlying cohesive formations, destabilizing the slope by causing pore-water pressure to rise (Wilson 1970; Watson 1984). It is believed these conditions were met during periods of glacial retreat when valley walls were 


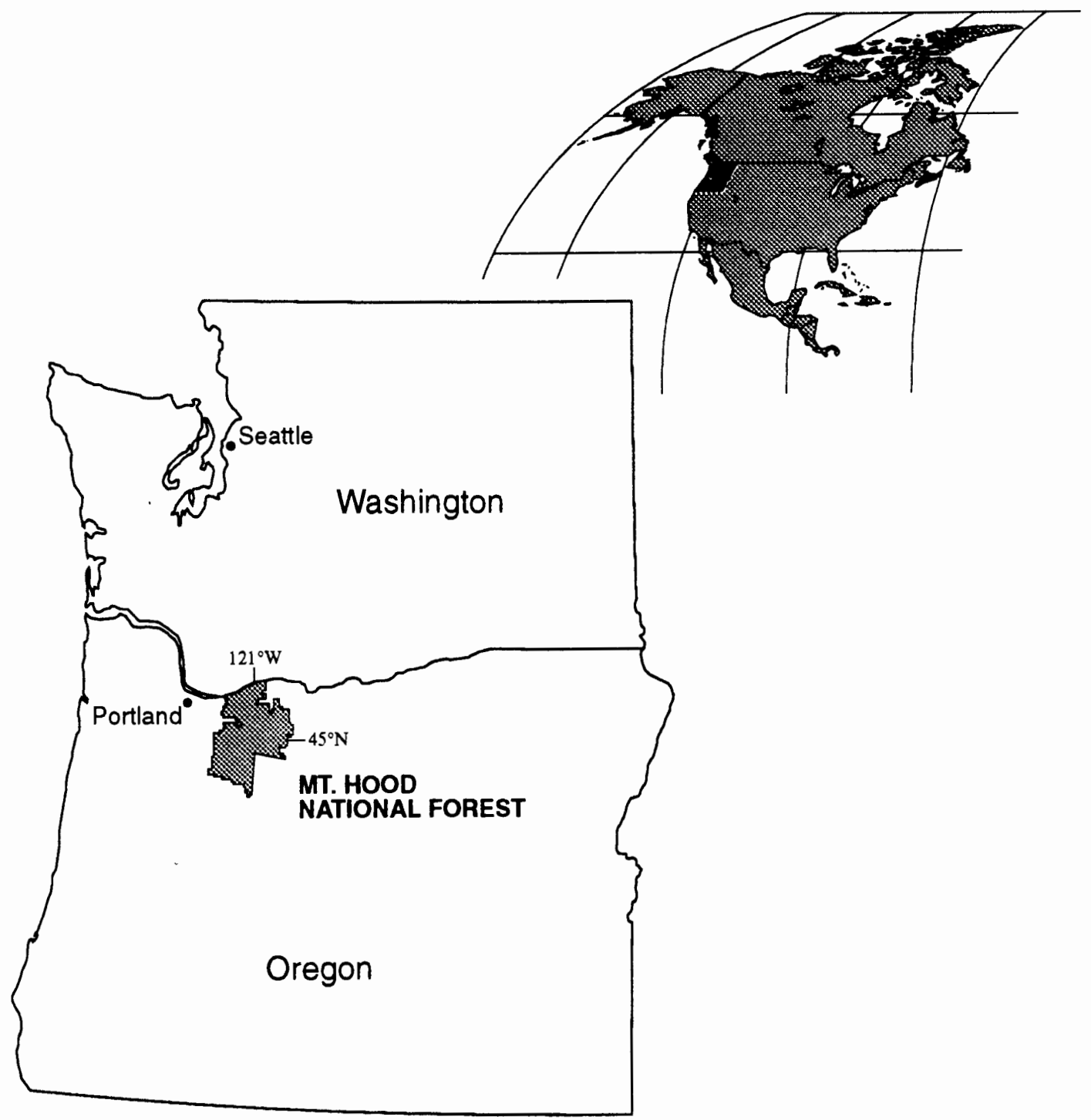

Figure 1. Mt. Hood National Forest Location Map. 


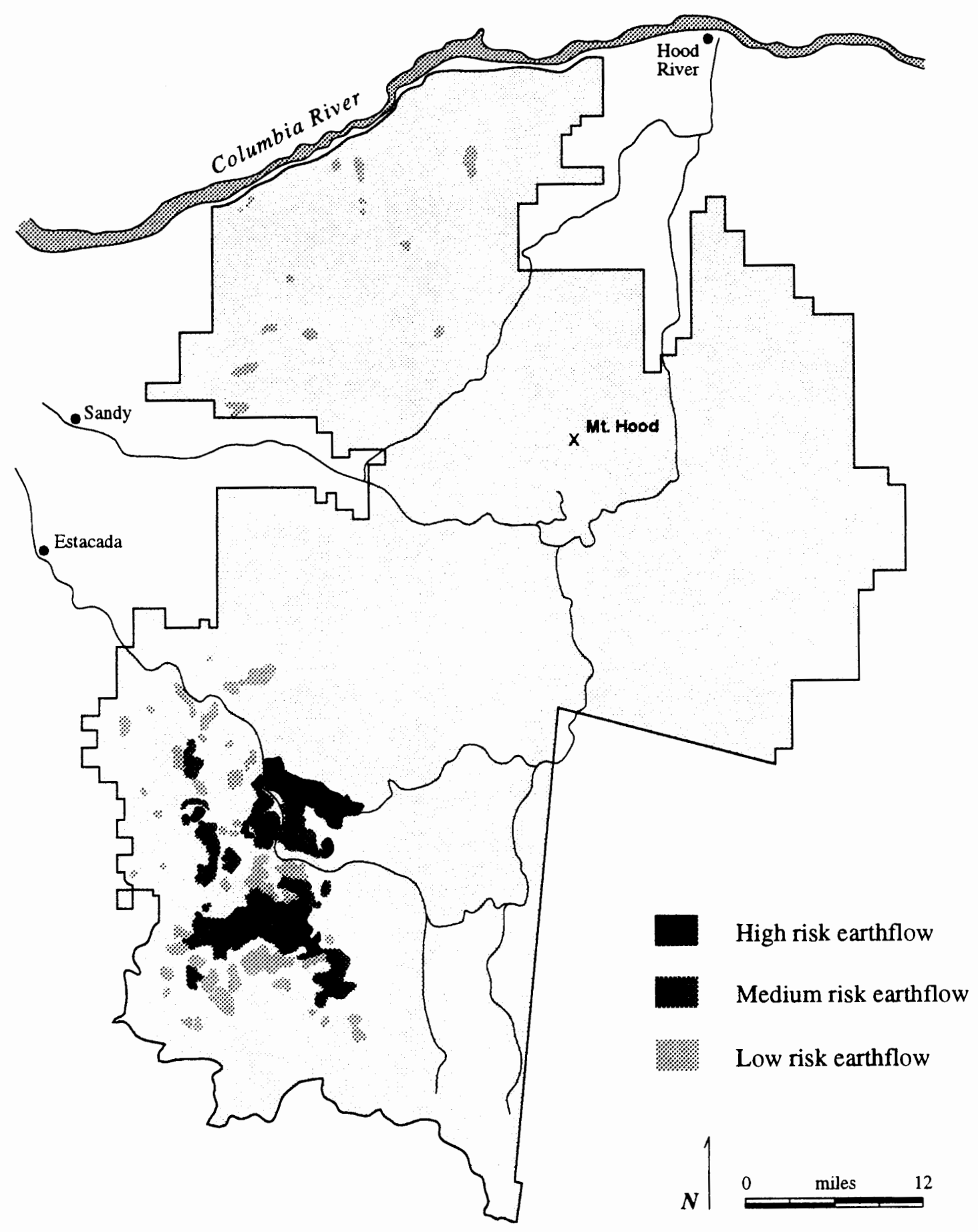

Figure 2. Earthflow distribution within the Mt. Hood National Forest. The majority of "earthflows" are located in the Clackamas and Estacada Ranger Districts. The risk categories shown are as they appear in the Forest Plan. 
oversteepened, unconfined, and saturated (c.f. Vulliet and Hutter 1988). Similar circumstances have been noted in the H.J. Andrews Experimental Forest, also in the western Cascade Range of Oregon, where "less than one percent of areas [underlain by] basalt and andesite flow rock have undergone slump-earthflow" failures (Swanston and Swanson 1976).

The primary drainage in the area is the Clackamas River, which flows northwesterly into the Willamette River. Additional drainage is provided by two of its major tributaries: the Oak Grove Fork and the Collowash River. Local relief is approximately 1000 meters. Valley walls are quite steep, often 45 degrees, and frequently represent the headwall scarps of Quaternary landslides (Figure 3). In general, unaltered, resistant lava flows cap the ridges, and landslide deposits mantle the broad valley floor. The landslide deposits consist of an unstratified melange of fragments from all nearby formations.

Using the terminology of Keefer and Johnson (1983), many of these deposits are more aptly referred to as earthflow complexes: i.e., an assemblage of earthflow deposits and active earthflows. It is conceivable that, as conditions favoring instability are created, the percentage of land in an earthflow complex occupied by active earthflows will increase. Such conditions are met seasonally, to be sure, when winter precipitation raises the water table, but may also be met at much greater time intervals by climate change, regional uplift, and changes in river base-level. Currently, active earthflows constitute approximately 15 percent of the study area. 


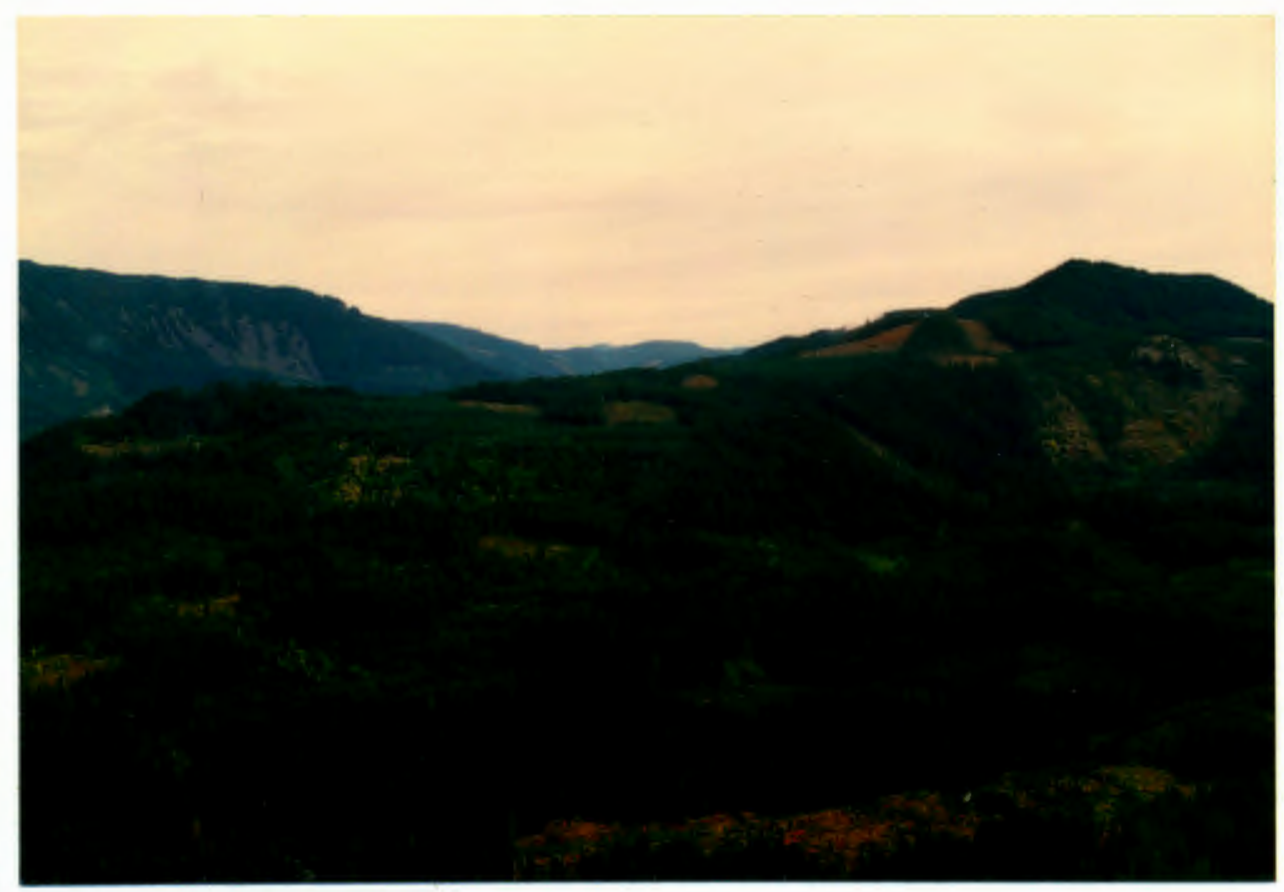

Figure 3. Oblique Aerial View of Road 46 Earthflow Complex. A Pleistocene landslide scarp is in the middle-ground; landslide deposits cover the valley floor. Note the extent of timber harvesting. 


\section{GEOLOGY}

The study area consists of five main formations and scattered intrusions (Figure 4). The Rhododendron Formation and the Beds of Bull Creek are unstable volcaniclastic formations comprised of tuffaceous breccia. These flat-lying units are thinly and discontinuously overlain by the more competent Grande Ronde Basalt Formation, and underlain by either volcaniclastic rocks of the Little Butte Volcanic series or Andesite of Nohorn Creek. Pliocene age intrusions, which range in composition from basalt to granidiorite, may disrupt the formations and are frequently visible adjacent to rivers where they have been exposed by erosion. Zones of material altered hydrothermally and by contact metamorphism also occur and are often the site of more rapid weathering and instability. The geology is further complicated by numerous southeast-northwest trending faults which transect and disrupt many rock units.

The formations of interest are described below in their approximate order of occurrence, from oldest to youngest. The unit descriptions are summarized from Dyhrman (1975), Anderson (1978), and Schulz (1980); quoted information is from Hammond and others (1982).

1. Breitenbush Formation: This formation, 20 to 18 m.y. in age, has four distinct members which consist of "pyroclastic flows, interbedded volcaniclastic beds, and minor andesitic lava flows. Maximum thickness of the formation is 915 meters." Individual members range in thickness from 50 to 150 meters, and members are separated by andesitic lava flows or volcaniclastic rocks. The formation is largely incompetent and unstable. 
Tr Rhododendron Formation

Tgr Grande Ronde Basalt

Tbc Beds of Bull Creek

Tn Andesite of Nohorn Creek

$\mathrm{Tb}$ Breitenbush Formation

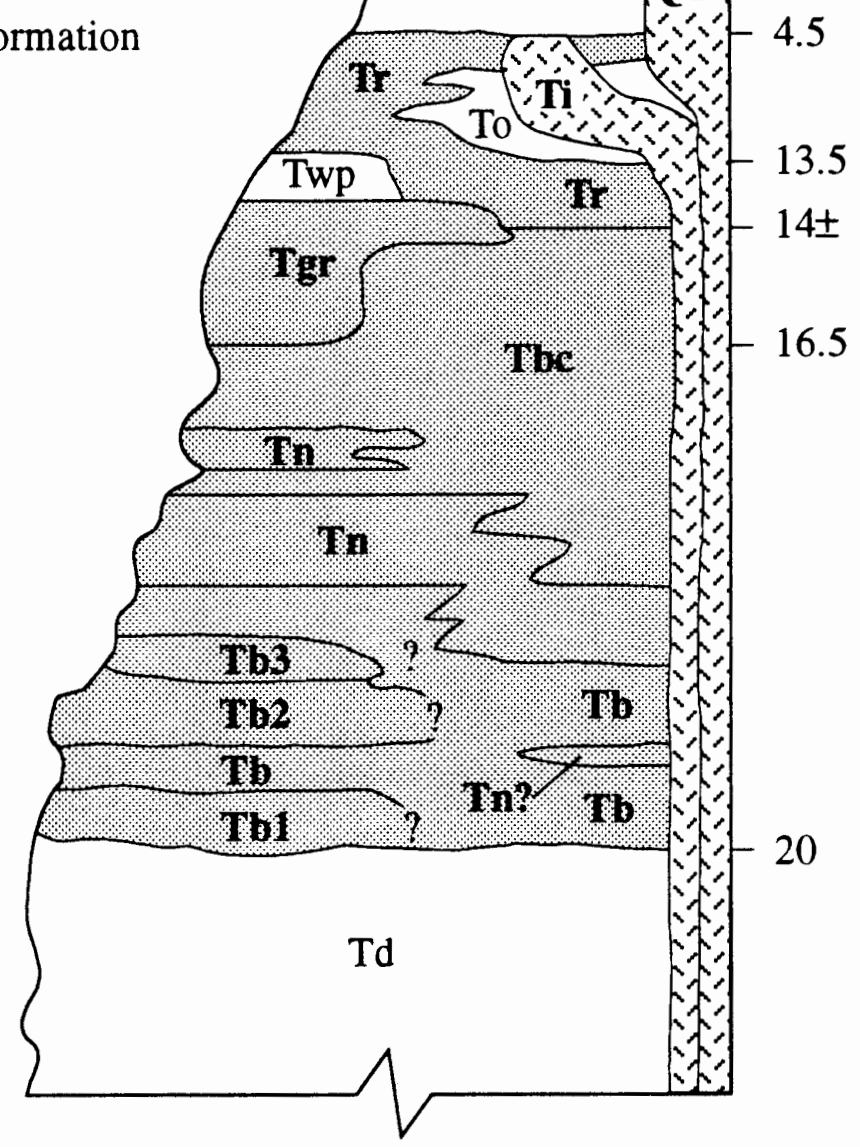

Figure 4. Stratigraphic Sequence of Geologic Formations in the Study Area. Adapted from Hammond and others (1982). Relevant formations are shown in gray. Intrusions are hatched. 
2. Andesite of Nohorn Creek: This formation is approximately 20 to 16.5 m.y. of age (Figure 4) and "consists chiefly of lava flows, individually 30 to $40 \mathrm{~m}$ thick, and minor fluvial volcaniclastic and tuff interbeds up to $6 \mathrm{~m}$ thick. The maximum exposed thickness of the formation...is about 490 meters. The lavas consist predominantly of dark-brown to reddish-brown pyroxene andesite porphyry, forming block flows within breccia margins."

3. Beds of Bull Creek: This formation is approximately 20 to 14 m.y. in age and consists of thick, interstratified laharic deposits, brown to dark grayish-purple in color, and thinner, clay-rich, fluvial volcaniclastic conglomerates and sandstones. Minor basaltic and andesitic lava flows also occur. "The beds are interpreted to be chiefly distal fluvial deposits, the products of the erosion of volcanoes constructed of interstratified andesite lava flows of Nohorn Creek and [certain tuffaceous formations]." The best exposures of this formation are located in the scarps of large Quaternary landslides, where the beds are intercalated with the Nohorn Creek and Grande Ronde Basalt formations (Figure 4). Maximum exposed thickness of the beds is about 375 meters.

4. Grande Ronde Basalt: The Grande Ronde, a member of the Columbia River Basalt Group, is dark gray, fine-grained, and middle Miocene in age (Figure 4). Its maximum thickness is roughly 370 meters, with individual flows ranging in thickness from 10 to 90 meters. Most flows "have well-developed hackly entablatures and less prominent colonnades." Beds of volcanic detritus are intercalated between more competent flows. These range in thickness from 3 to 40 meters (Anderson 1978; Schulz 1980).

5. Rhododendron Formation: The Rhododendron formation, middle to late Miocene in age (Figure 4), has a maximum thickness of about 915 meters. It is dominated by laharic deposits of andesitic tuff breccia (Sherrod and Conrey 1988). The lower part of the 
formation is comprised of gray pyroxene andesite porphyry lava flows and light-colored laharic and pyroclastic deposits. The upper part of the formation consists chiefly of darkcolored lava flows of olivine-pyroxene andesite porphyry, interbedded with light-colored laharic deposits and volcaniclastic beds. "Individual lava flows and laharic deposits range from 6 to 45 meters thick; tephra and pyroclastic flow deposits range from 3 to 180 meters thick."

\section{CLIMATE AND HYDROLOGY}

The long-term average annual precipitation ranges from approximately 1600 to 1800 $\mathrm{mm}$ per year, and varies most noticeably with elevation (USFS 1990a). The majority of this precipitation is associated with cyclonic winter storms, though summer convective rainfall is also common. The study area falls within the transient snow zone, which refers to a range of elevations over which snow packs tend to accumulate and melt away several times during winter (Harr 1986). Rapid melting is often initiated by rainfall, and the ensuing "rain-on-snow" event may produce peak streamflows, debris torrents, and sudden, rapid landsliding (Coffin and Harr 1992). The specific response of earthflows to rain-onsnow events has not been addressed, but some studies report that persistent earthflow movement is influenced more by the seasonal accumulation of soil moisture than by the kinds of changes produced during single events, such as those of the rain-on-snow variety (Sidle 1985). Other workers, however, have observed correlations between single storms and earthflow movement when pore water pressure has already exceeded some threshold value (Phillips pers. comm. 1993). Sag ponds and perched water tables are common throughout the area and contribute to earthflow movement by increasing the period over which water is available to the slide (Watson 1984). 


\section{VEGETATION}

The study area is located within the Western Hemlock climax zone (Franklin and Dyrness 1973; Halverson et al. 1986). However, few old growth Western Hemlocks (Tsuga heterophylla) are found because of timber harvests over the past forty years. Instead, Douglas-fir (Pseudotsuga menziesii) is dominant and is the species most frequently replanted because of its value as lumber. It may be found in pure or mixed stands and can reach heights of 60 meters.

On undisturbed sites, the overstory consists primarily of conifers. In addition to Douglas-fir, there are several less abundant species. Western Redcedar (Thuja plicata) is typically found in moist environments, often adjacent to sag ponds or within riparian zones where the ground is relatively level. Though less prevalent, Grand Fir (Abies grandis) and Pacific Yew (Taxis brevifolia) also occur. Grand Fir can reach heights of 60 meters or more, but those found in this vicinity are generally less than 20 meters tall and grow in the shade of the Douglas-fir canopy, scattered along valley floors below elevations of about 600 meters. Pacific Yews, which are rarely more than 10 meters high, are found only on shaded stream banks below elevations of about 800 meters.

Deciduous trees are dominant in wetlands, riparian zones, and disturbed sites. The most abundant deciduous trees are Red Alder (Alnus rubra) and Big Leaf Maple (Acer macrophyllum). These grow quickly, prefer moist soils, and thrive in sunlight. Often they are the pioneer tree species and may even be found growing on gravel bars in the middle of rivers.

Shrubs which make up the understory include Vine Maple (Acer circinatum), Service Berry (Amelanchier alnifolia), California Hazel (Corylus cornuta), Rhododendron (Rhododendron macrophyllum), Dwarf Oregon Grape (Berberis nervosa), and Salal, (Gaultheria shallon). Groundcover consists of Vanilla Leaf (Achlys triphylla), Bracken 
Fern (Pteridium aquilinum), Inside-out Flower (Vancouveria hexandra), Swordfern, (Polystichum munitum), and Oregon Oxalis (Oxalis Oregana).

The presence of certain specialized shrub and herb species often indicates a particular environment. Plants that thrive in saturated soils, known as hydrophytes, indicate areas of prolonged wetness and are therefore valuable in slope stability investigations (Chatwin et al. 1991). Some hydrophytes used as indicators in this study are Maidenhair Fern (Adiantum pedatum), Devil's Club (Oplopanax horridum), and Skunk Cabbage (Lysichitum americanum).

\section{SOILS}

Of the five factors of soil development established by Jenny (1941), only parent material and topography vary within the study area; time, climate, and vegetation are essentially identical. The time that has elapsed since the outset of soil formation is consistent throughout the study area because of Pleistocene glaciation and large-scale landsliding in the early Holocene. The climate is constant because the study sites are located within a few miles of each other at similar elevations. Vegetation varies locally but tends to reflect rather than modify soil conditions. Although topography is not constant, its effect on soil development has been negated by the redistribution of material due to landsliding and the renewal of the surface due to glaciation.

The typical parent material in landslide deposits is tuffaceous breccia, while soils adjacent to landslide deposits tend to form in unaltered basaltic and andesitic lava flows. Within a given landslide deposit, however, local variation in parent material is the key factor responsible for differences in soil characteristics. Although these differences are locally evident, widespread patterns are difficult to identify because of the heterogeneous nature of the deposits. 
Under the USDA Soil Classification, the predominant soil types found within the study area are all Inceptisols: Typic Haplumbrepts, Andic Haplumbrepts, Andic Dystrochrepts, and Typic Eutrochrepts (USFS Soil Resource Inventory 1979). The mean annual soil temperature ranges from frigid $\left(0-8^{\circ} \mathrm{C}\right)$ to mesic $\left(8-15^{\circ} \mathrm{C}\right)$, depending on elevation. Shallow moisture contents range from about 20 percent during the late summer months to over 50 percent in early spring. Deeper soils, particularly those found on active earthflows, may be saturated for much of the year and moisture weight approaches the weight of the solids.

Soils forming in landslide deposits have a layer of ground litter, primarily conifer needles, whose maximum depth is about 8 centimeters. Overall soil development is weak, and varies on average from an $\mathrm{A}-\mathrm{C}$ profile to an $\mathrm{A}-\mathrm{Bw}-\mathrm{C}$ profile. The $\mathrm{A}-\mathrm{Bw}$ horizon boundary is often diffuse and irregular, while the horizon boundary above unweathered parent material tends to be abrupt. The A horizon is typically a dark, grayish brown or brownish red silty clay or silty clay loam, 25 to 40 centimeters thick. The Bw horizon is similar in color, though ped structure is coarser and consistence somewhat firmer. Unweathered parent material shows extreme color variation due to the type of material and its differing states of reduction and oxidation. 


\section{CHAPTER III}

\section{LITERATURE REVIEW OF EARTHFLOWS}

\section{BACKGROUND}

Mass-wasting is defined as the en masse transfer of rock, weathered debris, and organic matter in response to gravity (Whittow 1984). Although water facilitates this process, it does not actually transport the material. Erosion, in contrast, is the entrainment of individual particles and depends on transport by water, wind, or ice (Whittow 1984). Mass-wasting occurs when the average shear stresses along a potential failure surface exceed the available shear strength along the same surface (Chandler 1986; Bromhead 1992). When in equilibrium, shear strength equals or exceeds shear stress. During times of disequilibrium, the slope readjusts its form until the balance between driving and resisting forces is restored (Iverson 1986a). Local conditions determine the amount of time required to achieve this state, and mass-wasting is the essential process involved.

Classifications of mass-movements are often based on process, rate of movement, and moisture content (Figure 5).

Landslide is the word most frequently associated with large-scale mass-wasting, and often it is used colloquially as a catch-all for slope-movements (c.f. Varnes 1978). In the United States, the cost of landslide destruction exceeds that of all other natural hazards combined (National Research Council 1985), and is estimated to be in excess of one-billion dollars each year (Schuster 1978; Hays 1981; Schuster and Fleming 1986; Brabb 1989). Landslides are also the cause of thousands of fatalities (Sidle et al. 1985). A third cost, which is difficult to measure and often goes undetected, is the degradation of natural 
Flow

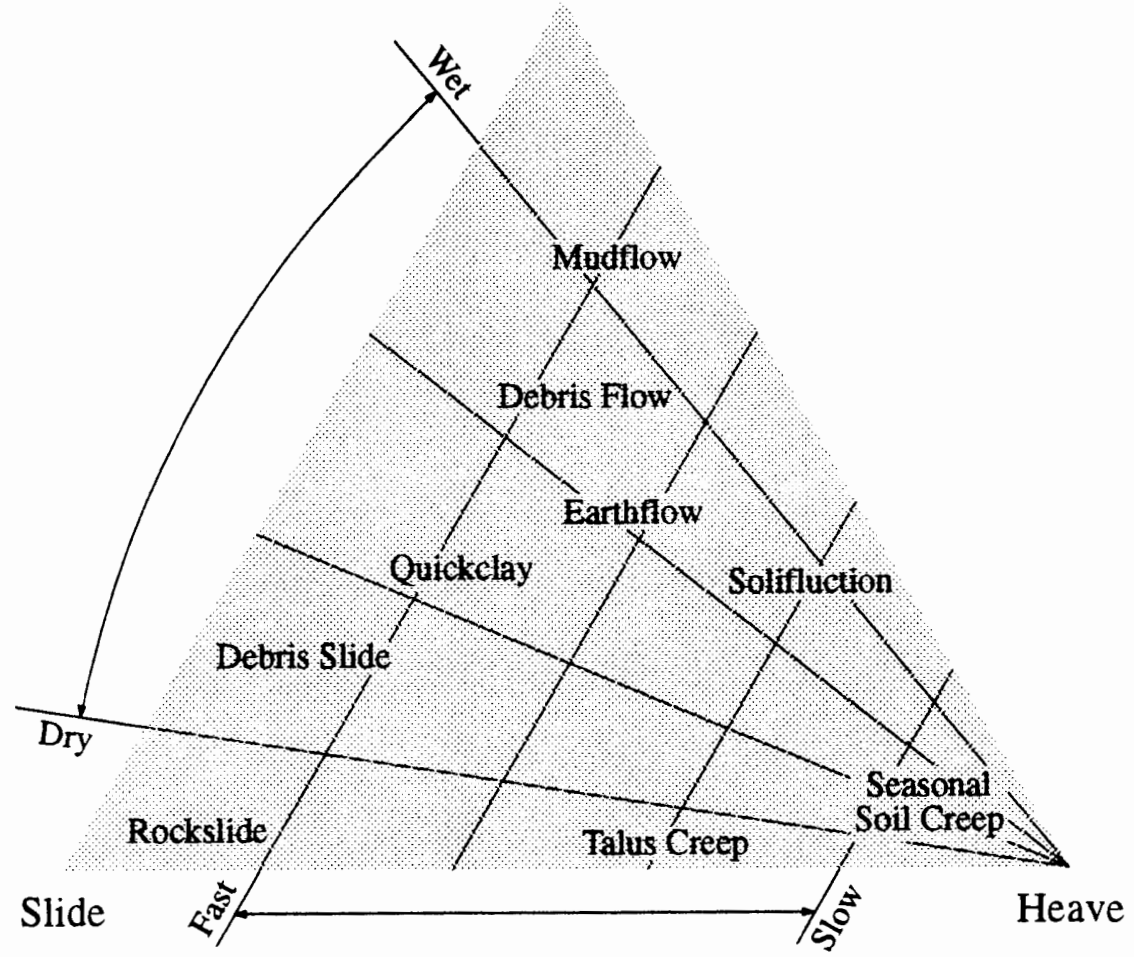

Figure 5. Mass-Movement Classification. Based on process, rate, and moisture content. (Adapted from Whittow 1984 and Ritter 1986) 
resources and aesthetically valued landscapes. Concern over this type of impact has grown in recent decades as environmental awareness and ecosystem management have developed (Rowe 1992; FEMAT 1993). It is this cost of landslides that prompts much of the current interest in earthflows.

\section{DEFINITION}

As used here, an earthflow is a large, elongated mass of moist, cohesive soil and weathered debris, whose persistent downslope motion occurs within discrete boundary shear zones (Figure 6). The primary method of movement is basal shearing, but creep, rotational displacement, and viscous flow-like displacements also occur (Figure 6). This definition is a generalized version of those expressed in numerous studies (Záruba and Mencl 1969; Keefer 1976; Kelsey 1978; Keefer and Johnson 1978, 1983; Nolan et al. 1979; Bovis 1985, 1986; Iverson 1986a; Pyles et al. 1987; Swanston et al. 1988; Zhang et al. 1991a, 1991b, 1993). The wording is intentionally devoid of soil, vegetation, moisture, size, depth, movement rate, and slope requirements because earthflows are highly variable in terms of these.

Earthflows are often confused with debris flows, but there are many differences. While earthflows are bounded by distinct shear zones, debris flows are typically confined to narrow and comparatively steep channels (Figure 7) (Costa 1984; Johnson 1984). Earthflow movement often persists for months or longer, while debris flows are episodic events that are mobilized, transported, and deposited generally in a matter of minutes or hours (Innes 1983; Johnson 1984). Earthflow movement occurs when high pore water pressure is sustained for some duration; in contrast, debris flows are triggered by abrupt increases in pore water pressure associated with heavy precipitation or rapid snowmelt (Costa 1984; Wieczorek et al. 1989; Coffin and Harr 1992). Although earthflows and 


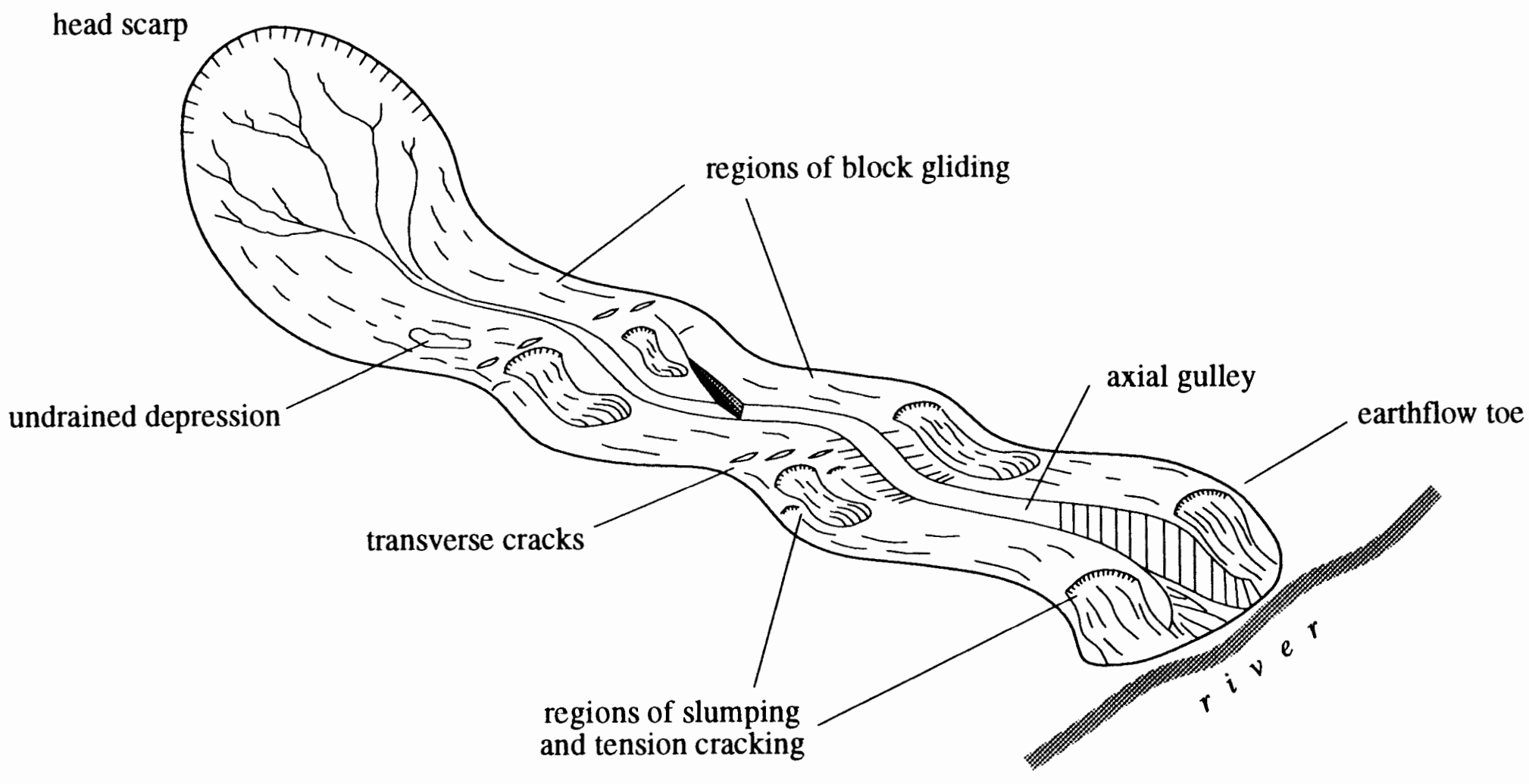

Figure 6. Idealized Earthflow. 


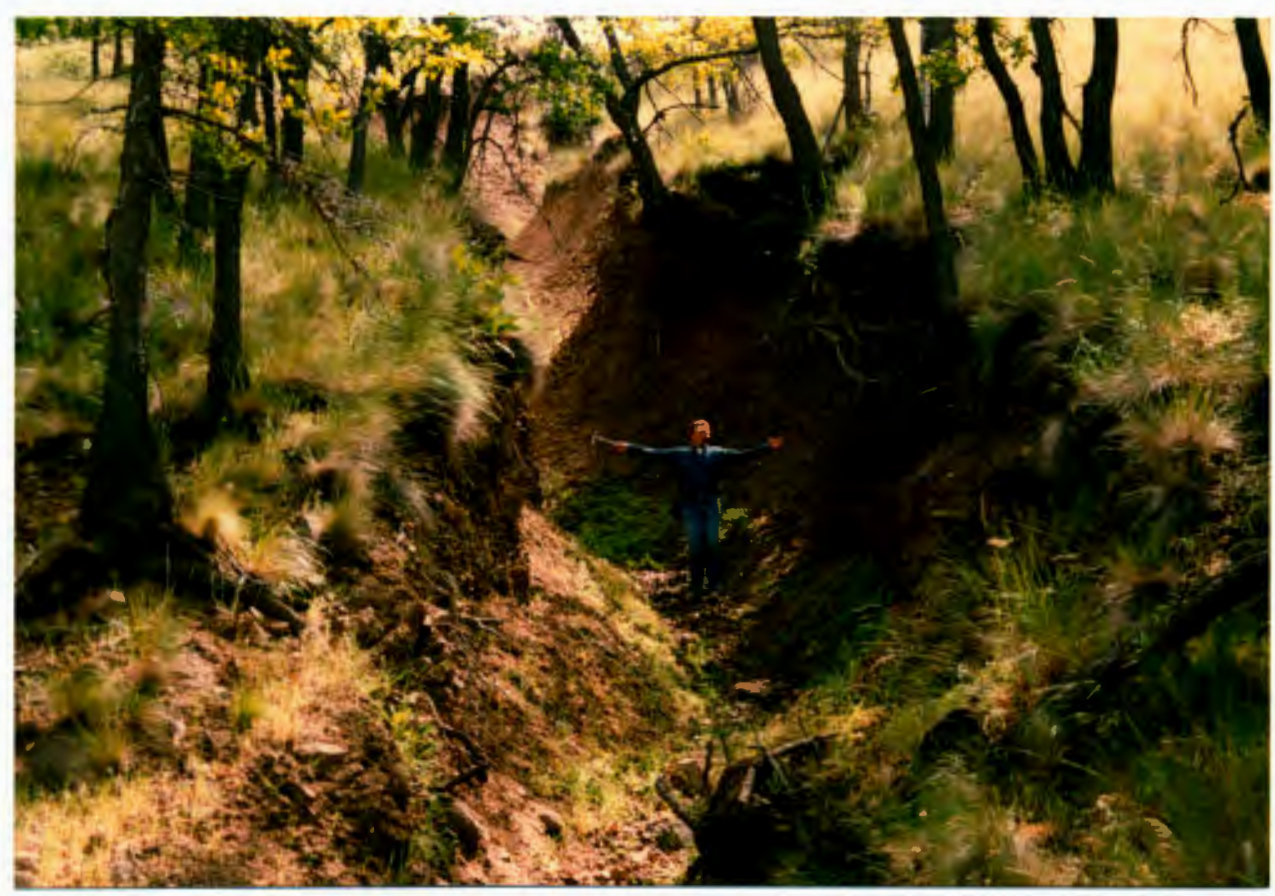

Figure 7. Debris Flow Channel. Note that the particle sizes are coarse, the slope steep, the channel narrow, and the climate somewhat arid in comparison to climates typical of earthflow terrain. Geologist for scale. 
debris flows both occur where precipitation is abundant, debris flows are also common in arid regions where they are associated with single storm events (Bowles 1985). In composition, earthflows contain large amounts of clay and water, while debris flows are predominantly coarse-grained and contain comparatively small amounts of entrained water (Iverson and Denlinger 1987; Phillips and Davies 1991). Earthflows move primarily by boundary shear, with little internal deformation. In contrast, debris flows travel as semicoherent plugs of material which surge downslope and undergo continuous internal deformation as they flow within their channel (Johnson 1965, 1970; Costa 1984; Iverson and Denlinger 1987). Unlike earthflow deposits, debris flow deposits are seldom remobilized (Costa 1984).

Earthflows typically occur in moderately sloping terrain where fine-grained, clay-rich soils mantle the slopes (Varnes 1978; Iverson 1986a). They range in size from about one hectare (Swanston and Swanson 1976) to hundreds of hectares (Bovis 1985). Earthflows are often shallow, one to three meters in depth (Keefer and Johnson 1983), but can range in thickness up to several tens of meters (Iverson 1986a). A distinction can be made between an active earthflow which is simply the area currently moving, and an earthflow complex which is an assemblage of active earthflows and earthflow deposits (Keefer and Johnson 1983). In appearance and behavior, earthflows have been likened to glaciers, and while they have been known to surge (Keefer and Johnson 1978, 1983), earthflows have not yet been observed to ablate.

In terms of their activity, earthflows may be short-lived, accomplishing their movement in a matter of minutes or days, or they may be ancient features showing recurrent activity over thousands of years (Swanston and Swanson 1976; Bovis 1986). When earthflows are reactivated, either by human or natural influences, they tend to do so within preexisting shear boundaries. Rates of earthflow movement encompass a wider 
spectrum than all other types of mass movements, ranging from meters per day or month (rapid) to meters per decade or century (slow).

The earthflow surface and the adjacent ground surface may change in relation to one another as the supply of earthflow debris diminishes. When changes in the height of the slide mass do not occur, the system is taken to be in the steady-state: the supply of debris matches its removal (Iverson 1984; Zhang et al. 1993). If removal of earthflow debris outpaces supply, or if the supply is limited, the earthflow will ultimately expend itself, and the height of its deflated surface will be lower than the adjacent natural ground.

Earthflows persistently transport sediment from distant hillslopes to riparian zones, crossing low-gradient valley floors in the process (c.f. Swanson et al. 1982a). Although the actual delivery of sediment to streams often occurs by discrete failures such as debris slides and slumps (Figure 8), the role of the earthflow is critical. With the exception of solifluction, no other discrete slope movement is capable of transporting such large amounts of sediment, over gradients as low as a few degrees, in such a persistent manner. Hence, earthflows are also important to the evolution of landscapes.

Earthflows are associated with a variety of rock types located around the world (Keefer and Johnson 1983). Some of the more common include argillaceous and sedimentary rocks of the Franciscan assemblage in northern California, the London clay in southeastern England, and bentonitic shale and claystone in Wyoming. Earthflows have been the subject of numerous geologic investigations (Keefer and Johnson 1983; Bovis 1985; Zhang et al. 1993), as well as geotechnical investigations (VanDine 1980; Rawlings 1984; Thomas and Kropp 1989). Some earthflows, particularly the rapidly-moving or quick clay variety, have been investigated as natural disasters (Smalley et al. 1975). Other earthflows have been studied in the context of ecosystem management, hinged on their role as sediment producers and their response to land management activities (Kelsey 1978;

Swanson et al. 1982b, 1987, 1990; Swanston et al. 1988). 


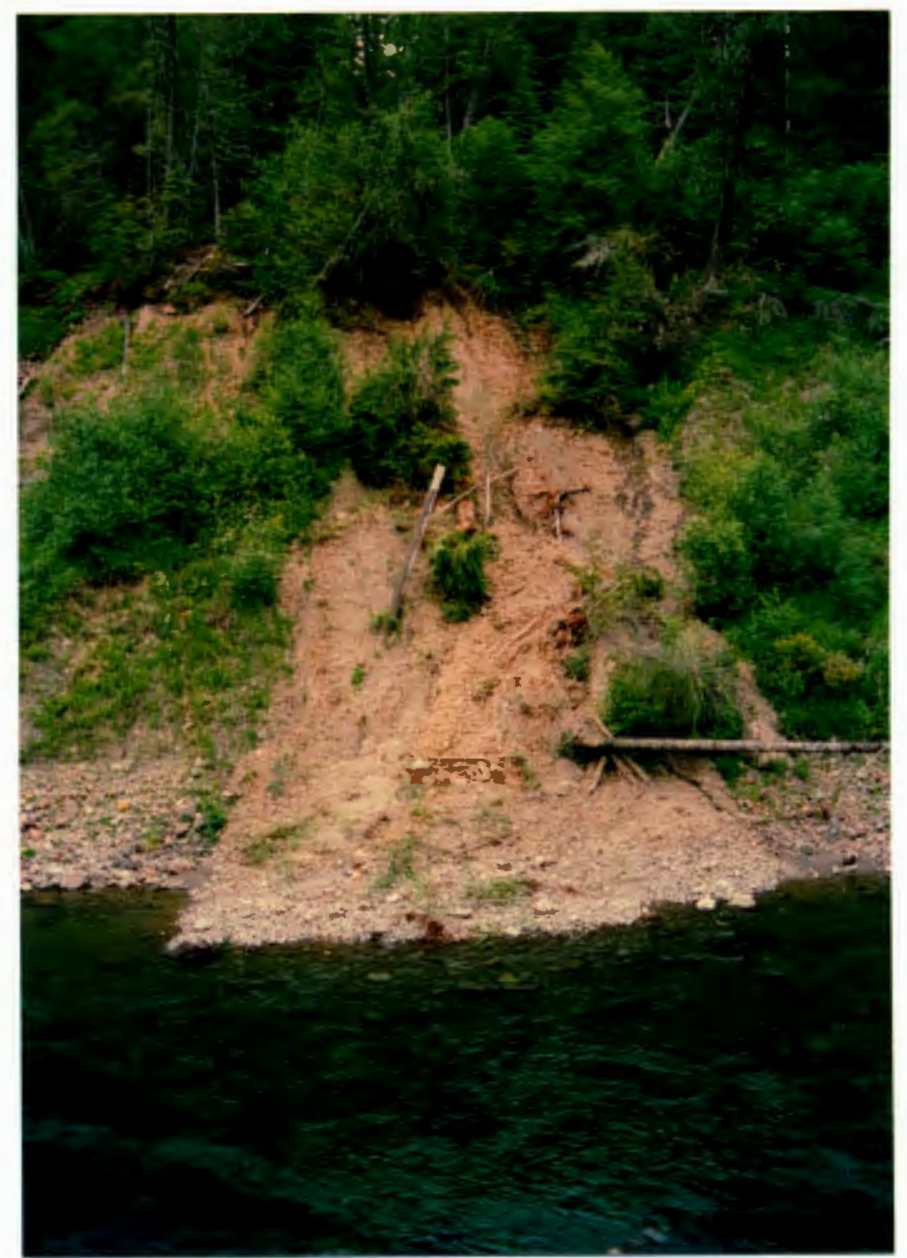

Figure 8. Debris Slide in Earthflow Toe. Sediment delivery is often facilitated by discrete slope movements at earthflow toes. Peak flows quickly remove deposits such as this one. 


\section{CLASSIFICATION}

Earthflows were first described in the literature in the early 1900s by Howe (1909) and Blackwelder (1912), though they were certainly recognized in nature long before this. In his seminal volume on landslides, Sharpe (p. 50-55, 1938) used the term earthflow to describe what are now recognized as two different processes. This generalization created some ambivalence over its meaning and led to the introduction of several redundant or overlapping terms. As Carson (p. 108, 1976) indicates, "The whole topic of earth flowage is badly confused by casual and inconsistent use of terminology." Some clarification regarding earthflow terminology is provided in Keefer and Johnson (1983).

Earthflows are often placed into either of two categories: rapidly-moving or slowlymoving. Although Sharpe (1938) refers to both as earthflow, his treatment of the process appears in his chapter entitled Rapid Flowage, perhaps hinting at the type of movement he considered typical. A distinction between these two types can be made in terms of their plasticity and cohesiveness. Materials with a propensity for rapid flowage tend to have low plasticity indices and transient cohesive strength. They are marked by "short-range fixed bonds" between cations and clay minerals which depend essentially on inter-particle contact (Smalley 1976). When this material is disturbed, the contact bond breaks, strength is lost, and failure occurs in a cohesionless, non-plastic fashion. Plasticity index values in the range of 12 to 18 percent have been published for these types of materials (Smalley 1976; Chandler 1986). In contrast, when the material comprising slowly-moving earthflows is disturbed, its "long-range mobile bonds" remain reasonably effective because they are not solely dependent on contact. Therefore, cohesive strength is maintained at some residual value (Cabrera and Smalley 1973).

The rapidly-moving variety of earthflow is often associated with quick clay and tends to occur in coastal lowlands where glacially-derived, sensitive marine clays are present 
(Bjerrum 1954; Bjerrum et al. 1971; Torrance 1987). Because quick clays are deposited in marine or brackish environments, their structure tends to be rich in adsorbed cations such as sodium. Following the uplift of previously submerged land, the cations may be leached from the clay structure which causes its overall ionic strength to be reduced and creates potentially unstable conditions (Rosenqvist 1966; Cabrera and Smalley 1973). Disturbances may initiate liquefaction, a spontaneous structural change wherein the brittle solid is effectively transformed to a liquid. In failure, this material may slump in a succession of wedges which liquefy upon collapse (Carson and Lajoie 1981). These types of quick clay flows are common in coastal British Columbia (Evans 1982; Thomson and Mekechuk 1982), Scandinavia (Rosenqvist 1953, 1966; Hutchinson 1961; Bjerrum et al. 1971), and eastern Canada (Crawford 1968; Smalley 1976). Similar types of slope movements occur elsewhere despite the absence of true quick clays; the prerequisite is merely material capable of behaving in a cohesionless fashion (Smalley 1976; Bromhead p. 83,1992$)$.

The slowly-moving variety of earthflow is the focus of this work and, with mild reservations, the term earthflow will continue to be used to describe it. While adequately descriptive, this term implies a mechanism of movement that is not always evident, and it ignores another which is often predominant, that of sliding or boundary-shearing. Blackwelder's (1928) early work highlights this inconsistency by suggesting that sliding accounts for more displacement than flow, evidenced by discrete boundary shear zones and a lack of internal deformation. Several authors have used the term "slump-earthflow" to address cases where the initial failure is a slump, and subsequent displacement of the mass occurs by a flow mechanism (Varnes 1958, 1978; Swanston and Swanson 1976). Many of the slope failures found in the Pacific Northwest fit into the slump-earthflow category (Schulz 1980; Swanston et al. 1988; Cumulative Effects Steering Committee 1992). 


\section{IDENTIFICATION}

The detection of earthflows is important to agencies such as the Forest Service that manage large tracts of mountainous wilderness. The standard first step is aerial photograph interpretation. Slowly-moving earthflows, however, are exceptionally difficult to detect and delineate because they produce only a subtle surface expression that is often concealed by a thick forest canopy. Furthermore, the canopy disturbances produced by slowlymoving earthflows may be imperceptible using standard remote sensing techniques.

McKean and Buechel (1990) have addressed this problem and conclude that even slight vegetative stress and minor canopy disruptions may reveal themselves within particular spectral bands. When understory vegetation, tree trunks, and other background materials become exposed through minor canopy openings, infrared reflectance increases. False-color infrared photographs show such areas to be more textured and of a higher spectral range (i.e., redder) than undisturbed sites. As earthflow movement rates increase, other spectral bands become effective for exposing the effects of disturbance. At a rate of a meter or more per year, the effects of disturbance are evident in the visible light spectrum. Thus, spectral and spatial analyses of multispectral imagery aid in identifying earthflows and delineating their boundaries, irrespective of movement rates.

\section{MOVEMENT}

Although the term earthflow implies a Bingham or visco-plastic type deformation, recent studies suggest the majority of an earthflow's displacement is accomplished by sliding along a discrete plane or by shearing through a narrow zone of weakness (Iverson 1984; Pyles et al. 1987; Zhang et al. 1991a). A much smaller proportion of displacement, typically less than 25 percent, is caused by internal deformation, and this may be a function of irregularities along the slip plane and not the innate tendency of the material (Zhang 
1991a). Thus, where the earthflow boundary is smooth, sliding and basal shearing will be the dominant means of displacement. Irregularities in the failure surface, such as monoclinal dips or depressions, will cause internal deformation by introducing a sort of turbulence to the slide mass. Keefer and Johnson (1983) refer to this influence as boundary roughness.

Earthflow mechanics were first considered about two decades ago, though much of the groundwork had already been laid. Cunningham (1972) found ample success at modeling an earthflow as though it behaved as a highly viscous fluid. More recent work has incorporated the idea of creeping flow, which refers to irrecoverable movement of regolith due to continuous gravitational stresses. In another model, Savage and Chleborad (1982) were able to predict velocity profiles of creeping flow in the upper two meters of a landslide. Van Asch and others (1989) indicate that yield strength values for viscous creep are comparable to the residual strength of the soil. Thus, for earthflows which mobilize out of landslide deposits at residual strength, shallow viscous creep may be a significant component of downslope movement.

Iverson $(1984,1985,1986 \mathrm{a}-\mathrm{c})$ has explored earthflow dynamics in a rigorously theoretical framework. He has developed a broadly applicable mathematical theory to help explain "unsteady, nonuniform landslide motion." The theory integrates physical principles of mass conservation with a constitutive equation describing complex massmovement behavior.

One of the most important elements of Iverson's theory is a dimensionless parameter known as the Peclet number $(\mathrm{Pe})$, which corresponds to the manner in which a landslide deforms. The $P e$ value, from which inferences about a landslide's rheology can be drawn, has implications for a landslide's sediment-flux response to perturbations. For example, a small value describes a rigid deformational response akin to translational block slides with very thin basal shear zones. In contrast, a large value describes a visco-plastic 
or viscous response to perturbations, typical of landslides with thick basal shear zones. Thus, if the landslide's $P e$ value is low (0.1 to 1.0), diffusive transfer of the sediment-flux perturbation occurs, producing a coherent response that is immediately and uniformly "felt" throughout the slide mass. If the $P e$ value is high $(10$ to $>100)$, the response is governed by kinematic waves that propagate away from the initial perturbation at 5 to 50 times the rate at which the sediment moves (Iverson 1984, 1986c). In this sense, a kinematic wave can be understood by thinking of an ocean wake that lifts objects floating on the surface as it passes but does not transport these objects (c.f. Sharp, ch.4, 1988). As distance from the perturbation increases, so does the response time. With highly viscous material, decades may elapse before the perturbation is felt (Iverson 1986a, 1986c).

Zhang and others (1991b) applied Iverson's theory to rapid earthflow movement in New Zealand. Using ten years of survey peg measurements, they found that the particle to particle contact that is responsible for actual down-slope movement is not the sole means that sediment-flux perturbations are transferred, but that Iverson's kinematic wave and diffusive behavior were also responsible. In another study, Zhang and others (1991a) explored the internal deformation of an earthflow by installing tiltmeters at various depths throughout the body of an earthflow. Their results indicate that the style of internal deformation reveals itself in the movement profiles recorded by the tiltmeters, and that microtopographic features influence these profiles and the predominant mode of displacement.

\section{GROUNDWATER HYDROLOGY}

Several papers have addressed the groundwater hydrology component of earthflows which is critical for a complete understanding of earthflows (Koler 1992). On this tack, Iverson and Major (1987) have discussed groundwater flow as it might influence 
mobilization and movement. They found that the pore pressure front from a single storm propagates down toward the base of the landslide, but often dissipates prior to reaching the slide plane. Therefore, its influence on landslide motion is small. In contrast, the pore pressure front from seasonal rainfall may attain a depth sufficient to mobilize or accelerate earthflows by altering effective stress at the slide plane, but often after a period of weeks or months. The response lag is controlled by the depth of the slide plane, the amount of rainfall, and the amount of water already present in the body of the slide.

Other workers have reached similar conclusions in a less theoretical fashion (Swanston and Swanson 1976; Swanson and Swanston 1977; Keefer and Johnson 1983; Sidle 1985). In sum, they indicate that shallow, rapid failures, such as debris slides and debris flows, are often initiated when high-intensity or long-duration storms cause pore water pressure to rise to some critical level. In contrast, deeply-seated earthflows respond with movement only after the gradual accumulation of seasonal rainfall has increased pore water pressure enough to sufficiently reduce effective stress at the slide plane.

Thomas and Kropp (1989) found that, in some cases, earthflow movement depends not only on the amount of rainfall received, but also on its timing. The earthflow they investigated showed little response to a rainy season 200 percent of normal when early rains were small. In contrast, during a rainy season of normal precipitation, when early season rains were large, substantial movement was triggered. In the first case, desiccation cracks, which formed after the dry summer season, were gradually closed by the early light rainfall. Later, when heavy rains fell, the cracks were already closed and could not conduct water to the slide plane. In the second case, the desiccation cracks could not close quickly enough to prevent mobilization caused by early heavy rainfall. The key is that they remained open long enough to act as conduits for runoff, which was directed toward the slide plane. 


\section{TIMBER HARVEST}

Many slope stability studies in the Pacific northwest have addressed the relationship between timber harvest and landslides. Most of these have focused on shallow hillslope failures such as translational slides and debris flows (Swanson and Dyrness 1975; Gresswell et al. 1979; Miles et al. 1984; Amaranthus et al. 1985; Wolfe and Williams 1986; Benda 1990; Neely and Rice 1990; Sidle 1992). Very few studies have attempted to monitor an earthflow's response to timber harvest (Koler 1992), though several imply that a direct relationship exists (Kelsey 1978; Pyles et al. 1987; Zhang et al. 1991b; Marden et al. 1992).

In one of the earliest works to consider the effects of timber harvest practices on deep-seated landslides, Gray (1970) postulated that forest cover influences slope stability through hydrologic modifications and root strength. Although each of these plays an important role in slope stability, hydrologic modifications appear to have greater implications for altering rates of earthflow movement and thus sediment production. Conversely, the influence of root strength on earthflow movement is minimal. In the Cascade Mountains, the average soil depth stabilized by roots is about one meter (Sidle 1985 ) and may be significantly less in earthflow terrain (Figure 9). Since an earthflow's basal shear zone is typically located several meters below the maximum rooting depth, roots are unable to anchor the slide mass to a competent substratum, and therefore provide little reinforcement.

Alternatively, most workers agree that root strength increases the stability of slopes where the potential for shallow, planar slides is high (Greenway 1987). Here, roots anchor the soil to bedrock or bind the soil mass to itself (O'Loughlin 1974; Sidle 1985). The lateral growth of roots allows them to become entwined with the roots of neighboring trees, producing a dense and continuously-bound mat of soil and roots. Lateral 


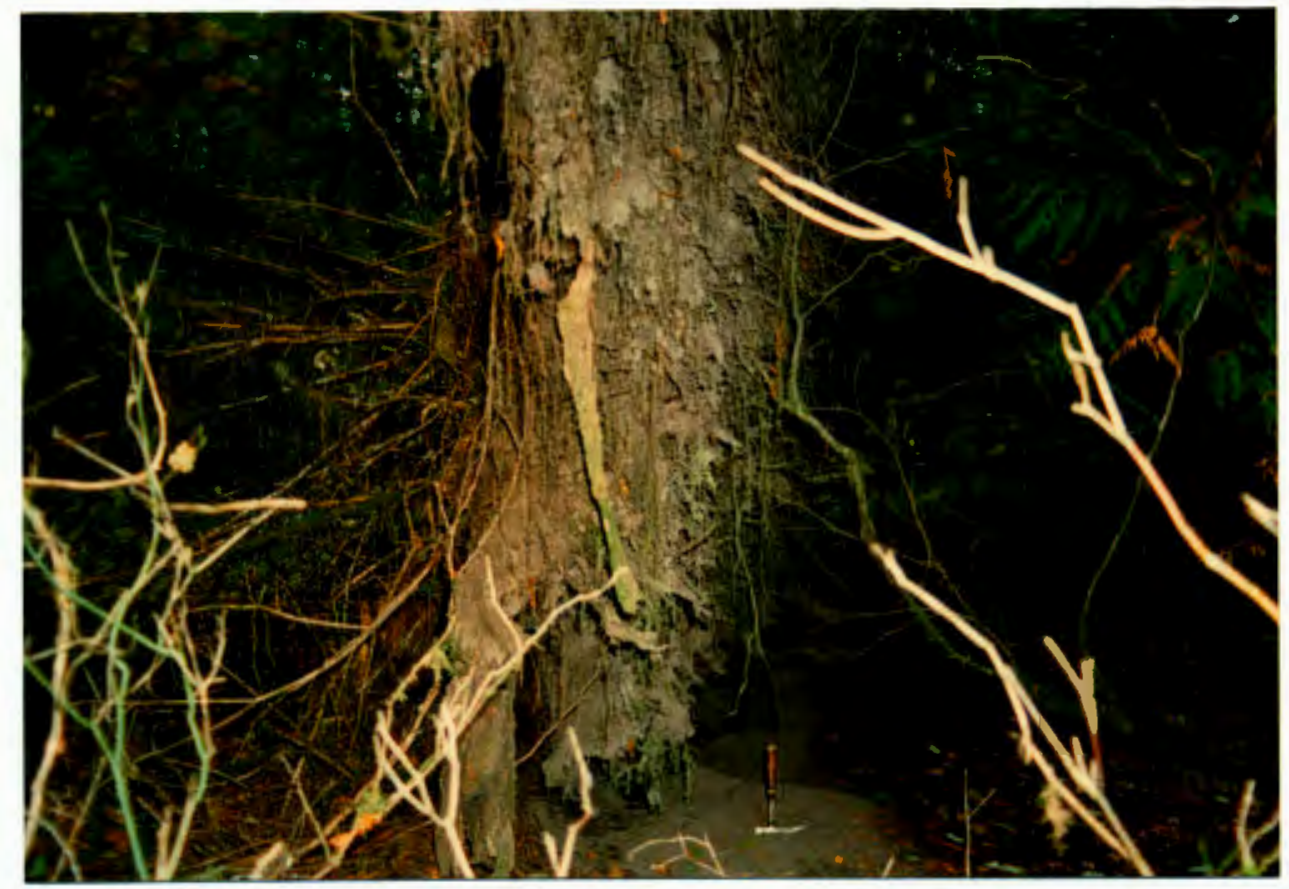

Figure 9. Shallow Root Network of Douglas Fir on Earthflow Terrain. These roots do little to anchor the soil mass to a more competent substratum. This rooting depth is typical where impermeable soil layers cause groundwater to remain near the surface. Rock hammer for scale. 
reinforcement by this mat or "membrane" may be important where it crosses planes of weakness or zones of potential instability (Swanson and Swanston 1977; O'Loughlin 1981). Such reinforcement may influence the deformational style of earthflows (Zhang et al. 1993), but probably has little influence on net downslope movement.

Swanston and others (1988) refer to the effects of root strength in perhaps the only published study where field data, collected over a ten year period of pre-harvest, harvest, and post-harvest, have been analyzed with the specific purpose of identifying the impacts of timber harvest on deep-seated stability. They assert that earthflow movements observed in the year following timber harvest could not be directly linked to reductions in mechanical reinforcement by tree roots because "it takes more than one year for root strength to deteriorate sufficiently to affect stability" (Swanston et al., p. 379, 1988). Therefore, the earthflow acceleration was attributed to modifications of the groundwater regime through declines in evapotranspiration. Moreover, their empirical observations of earthflow response to perturbation seem to concur with inferences drawn from the theoretical model of Iverson $(1984,1986 a)$. Specifically, one year after timber removal, accelerated movement was recorded in an inclinometer located down-slope from the clear-cut site. Some six months later, a similar amount of displacement was recorded 120 meters farther down-slope at the earthflow toe. Three years after timber removal, prelogging rates of movement returned. Thus, timber removal and the resulting changes in hydrology cause the propagation of a kinematic wave which moves several times faster than existing earthflow rates and whose diffusive behavior is reflected in the earthflow's Peclet number.

From a logistical standpoint, the effects of reforestation on earthflows are understandably difficult to consider. In New Zealand, fortuitous circumstances allowed Pearce and others (1987) to compare the behavior of a deforested earthflow to one vegetated with 15-year-old Radiata Pine (Pinus radiata). Their observations revealed 
order-of-magnitude differences in earthflow velocity. The annual movement of the deforested earthflow was 3 to 5 meters, while the reforested earthflow moved only 0.2 to 0.5 meters annually. This difference was attributed to greater evapotranspiration, interception losses in particular, on the forested earthflow. 


\section{CHAPTER IV}

\section{METHODOLOGY}

The U.S. Forest Service has mapped and monitored landslides on the Mt. Hood National Forest for more than twenty years. Through the mid-1980s, a number of Forest Service geologists and engineers made a concerted effort to map and classify earthflows into high-, medium-, and low-risk categories (DeRoo pers. comm. 1993). These categories were formalized when they were incorporated into the Forest Plan in 1990 (USFS 1990a). Based on this information and site-specific work by the Mt. Hood geotechnical staff, two active earthflows, two earthflow deposits, and three non-earthflow landforms were chosen for investigation. The criteria for these selections included the degree of earthflow activity, geology, landform age, climate, slope form, slope angle, elevation, and vegetation. The intention was to isolate the variables believed to have a strong influence over earthflow activity, while holding all other variables as constant as practical. For example, the influences of climate and age are considered constant, but parent material is not.

The earthflows and earthflow deposits were then examined using aerial photographs at a 1:12,000 scale for the years $1946(\mathrm{~b} / \mathrm{w}), 1959(\mathrm{~b} / \mathrm{w}), 1972,1979$ (false-color infrared), 1984, and 1989. In addition, a 1974 flight of high altitude black and white photographs at a 1:40,000 scale was available for widespread terrain analysis. Two closeup flights taken in the years 1974 and 1981 were available for more detailed viewing, but provided only partial coverage of the study area. Outstanding features were mapped for each earthflow and earthflow deposit to characterize them in terms of size, shape, activity, and morphology. This was accomplished by delineating areal features such as lobes, 
depressions, slumps, bodies of standing water, and variously-aged tracts of timber, and linear features such as the earthflow perimeters, shear zones, scarps, and drainage patterns.

Field mapping was broken into two main parts: "ground-truthing" those features identified from air photos, and mapping features not visible in air photos. The initial field mapping efforts were made with a Global Positioning System (GPS) unit owned by the Forest Service. After meager success, this method was abandoned because the costly GPS unit was found to be too cumbersome and vulnerable on steep terrain. Subsequent mapping attempts relied on following a transect oriented normal to the contours of the slope and recording earthflow features along the way. When an unusual earthflow feature was encountered, the transect was abandoned, and the feature was reconciled and mapped appropriately.

The difficulties encountered during field mapping varied inversely with the rate of earthflow movement because morphological development is so directly linked to movement rates. However, local variations in movement caused by microtopography can complicate the morphology and thus the mapping. It is also worth noting that mappable features occur at scales of small to large and young to old. For example, newly formed tension cracks are typically narrow and shallow, while older cracks may be a meter wide, roots spanning the distance, and several meters deep.

Primary sites for soil sampling were chosen along the longitudinal axis of each earthflow landform to capture changes in soil properties and soil development that might occur over the length of the slope. This also seemed to be a simple and reliable way to get representative coverage of the landforms. Sampling sites were located at significant slope breaks or, where these were not forthcoming, separated by some arbitrary distance. Additional samples were taken from surfaces unrelated to earthflow activity, both currently 
and historically. These include a basaltic intrusion, a glacial till deposit, and an alluvial terrace deposit.

In all, 96 soil samples were taken during March and April of 1993, generally the wettest time of the year according to local groundwater information. Thus, calculated values for field moisture contents do not encompass natural fluctuations and are far closer to the annual maximum than the mean. Most samples were taken from soil pits whose depths ranged from 0.5 to 1.4 meters, depending on the depth of the mineral soil. A few samples were taken from the faces of fresh scarps, stream channels, road cuts, and exposed surfaces at earthflow toes. The depths of these samples were as much as 5 meters. Average sample size was about 800 to 1000 grams, and the largest acceptable particle size was $76.2 \mathrm{~mm}$, the cutoff between gravel and cobbles (Casagrande 1948). Thus, fractions of gravel, sand, silt, and clay are expressed as percentages of all particles smaller that $76.2 \mathrm{~mm}$ (Casagrande 1948). Samples were stored temporarily in Ziplocrm freezer bags to maintain field moisture contents. Particularly fine soil exposures were classified in accordance with Soil Taxonomy guidelines (Soil Survey Staff 1975), and each horizon was sampled.

Soil tests were conducted in the soils lab at the Supervisor's Office of the Mt. Hood National Forest. Each of the three main tests followed designations of the American Association of State Highway and Transportation Officials (AASHTO 1986). Atterberg limits were determined for each sample using AASHTO Designations T 89-86 and T 9086, for the liquid and plastic limit, respectively. Particle size analysis followed AASHTO Designation T 88-86. Samples were dispersed for 24 hours in $50 \mathrm{ml}$ of a sodium hexametaphosphate solution $(50 \mathrm{~g} / \mathrm{l})$. Hydrogen peroxide was used for further dispersion and to help remove organic matter. The limits of particle size classes are as follows: clay = $<2 \mu \mathrm{m}$, silt $=2 \mu \mathrm{m}-0.074 \mathrm{~mm}$ (\#200 sieve), sand $=0.074-4.75 \mathrm{~mm}$ (\#4 sieve), and gravel $=4.75-76.2 \mathrm{~mm}$. Field moisture contents were determined using AASHTO Designation $\mathrm{T}$ 
265-86, and moisture is expressed as a percentage of the oven-dried sample. Each sample was classified using the Unified system (ASTM designation D-2487).

Using the results from these tests, several other soil properties were determined. The plasticity index (PI), which is the range of water contents over which a soil behaves like a plastic, was calculated for each sample by subtracting the plastic limit (PL) from the liquid limit (LL):

$$
\mathrm{LL}-\mathrm{PL}=\mathrm{PI} .
$$

The liquidity index (LI) is used to express field moisture contents (m) in terms of the plasticity index, and is calculated by:

$$
(\mathrm{m}-\mathrm{PL}) \div \mathrm{PI}=\mathrm{LI}
$$

The activity of each sample, which indicates of the strength of the negative charge of the clay and thus varies with clay type, was calculated by:

$$
\text { PI } \div \text { Percent clay }=\text { Activity }
$$

Dry unit weights were measured with an Eley Volumeter. Although this device works well with fine-grained, cohesive soils, it is less effective as grain size increases. Consequently, the values obtained for the coarser earthflow deposits and non-earthflow landforms are less accurate than those for active earthflows. Using the plasticity index (Voight 1973) and clay content (Skempton 1964, 1985), residual friction angles ( $\phi^{\prime}$ ) were estimated for each sample. The friction angles of non-plastic soil samples were estimated solely on the basis of clay content. Shear strength $(\tau)$ was determined using a vane shear device (Soiltest CL-612) at several sampling sites. Although the shear strength of most soils is a combination of cohesion and frictional resistance, vane shear readings are most accurate in pure clays where $\phi=0^{\circ}$ and shear strength equals cohesive strength. Since the 
vane shear does not distinguish between cohesion and frictional resistance, it is best suited for broadly comparative estimates of soil strength. Estimates of smectite content were made based on the work of Borchardt (1977) and Mutchler (1987), who observed that increases in smectite content were related to increases in plasticity index and liquid limit. Descriptive statistics and correlations were calculated using Statworks (v. 1.2). 


\section{CHAPTER V}

\section{DESCRIPTIONS OF STUDY SITES}

\section{BACKGROUND}

The study sites, which represent most of the surficial deposits found in the area, are located within the upper Clackamas River watershed in an area of ancient large-scale landsliding (Figure 10). Extensive logging has occurred throughout the study area, and earthflow activity may have increased as a result. Each active earthflow shows obvious signs of movement and has been monitored for a number of years. The earthflow deposits appear to be stable, or perhaps moving imperceptibly, but monitoring of these has only just begun. Since each earthflow landform terminates at or near a major river, the potential for acceleration or reactivation is substantial. The remaining study sites, which fall into the category of non-earthflow landforms, include samples from an alluvial terrace, a basaltic intrusion, and two deposits of glacial till, all of which appear to be stable.

\section{JUNCTION EARTHFLOW}

\section{Morphology}

Junction earthflow is one of several active earthflows situated within a large earthflow complex which extends from the headwall scarp of a Pleistocene landslide to the banks of the Clackamas River (Figure 11) (Shannon and Wilson 1975a, 1975b). Junction is located 


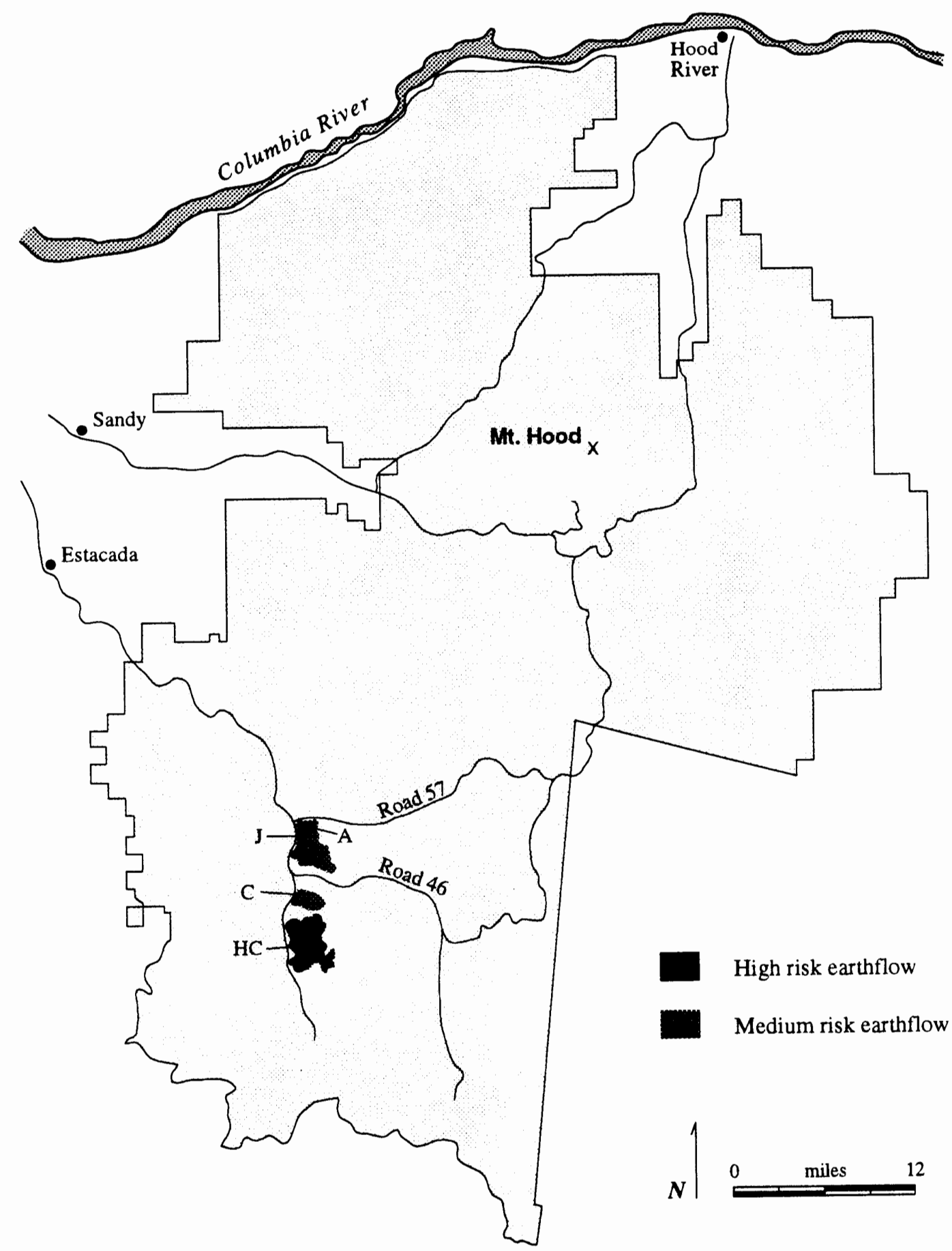

Figure 10. Earthflow Complexes of the Study Area. Includes Junction (J) and Collowash (C) earthflows and Alder (A) and Happy Creek (HC) earthflow deposits. 


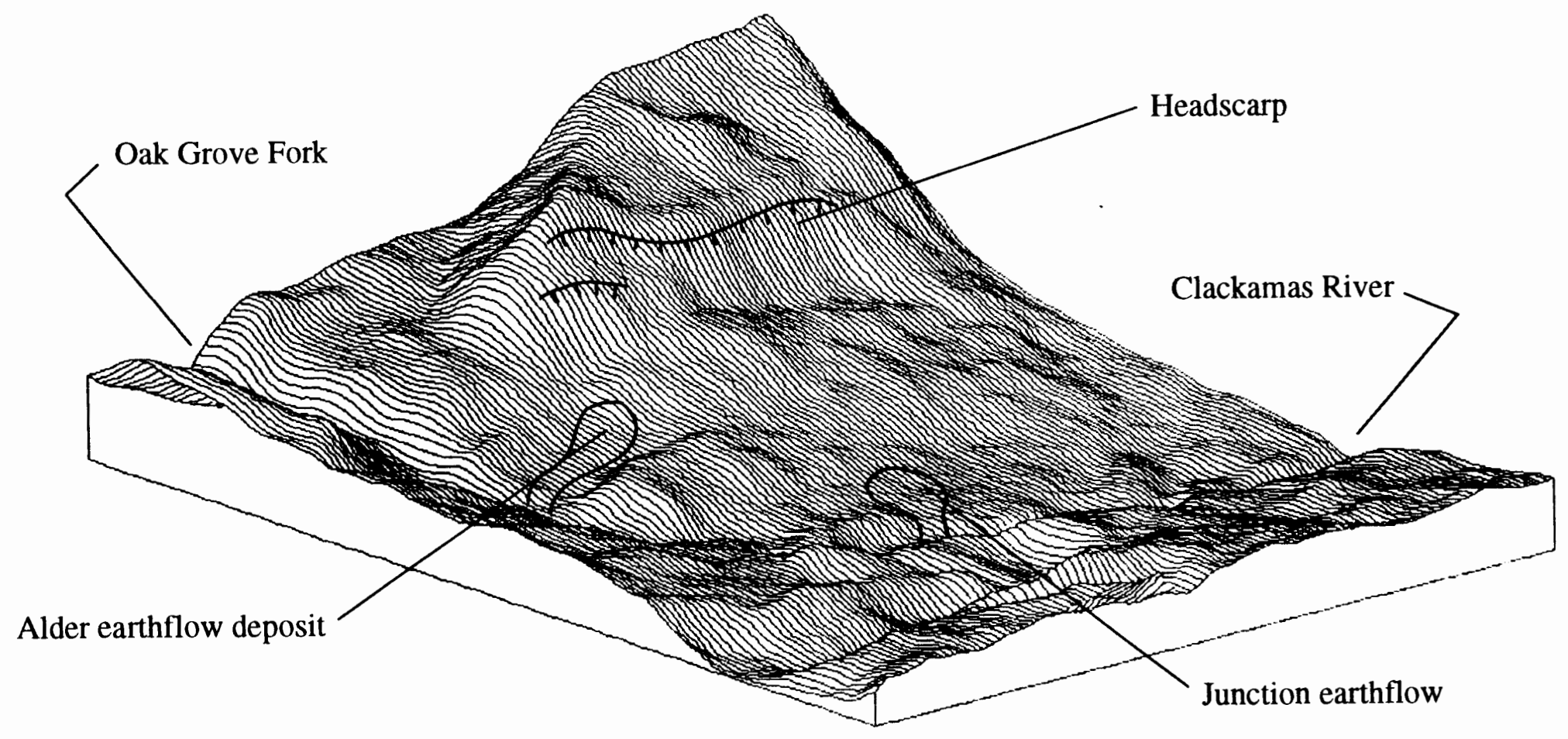

Figure 11. Road 46 Earthflow Complex. Pleistocene landslide deposits cover the valley floor. Headscarps form the steep valley walls. 
approximately two kilometers southeast of the Clackamas Ranger Station, and is crossed by Forest Service road 46 at the 1.5 kilometer mark. It consists of two distinct, overlapping lobes, whose fronts are separated by about 300 meters. The lower lobe appears to be stable, while the upper lobe is active and contains discrete blocks that move at different rates (USFS 1990b).

The area surrounding road 46 shows many signs of activity. Above the road, a series of small head scarps, roughly two meters deep, separate the earthflow from relatively stable ground. Below these scarps, the topography is highly irregular, and consists of secondary scarps, hummocks, leaning trees, tension cracks, desiccation cracks, and possible piping features more than one meter deep (Figure 12). The road prism, which overlies low strength fill material and landslide debris, has been intersected by scarps that cause curvilinear dips or cracks where they extend to the pavement. When groundwater levels are high, movement occurs along these slide planes causing the area inscribed by the scarps to drop as much as thirty centimeters per year (USFS 1990b). Decades of asphalt patching have increased the thickness of the pavement to two or more meters where movement and cracking are greatest.

Below the road, the active lobe extends some 200 meters at an average gradient of 7 degrees. The topography is irregular and marked by hummocks, depressions, standing water, tilted trees, and a distinctive toe, whose height and steepness is a function of velocity. Where downslope movement is greatest, along the central longitudinal axis, the lobe is thickest and rises abruptly to a height of roughly two meters. Toward the margins, the lobe thins steadily until, at the extreme edges of the earthflow, where velocity approaches zero, the lobe is barely discernible. Signs of activity near the toe include tilted trees, over-turned vegetation, and the abrupt form of the toe itself. In addition, the A horizon of the lobe wraps around the toe in conveyor-belt fashion. A short distance above 


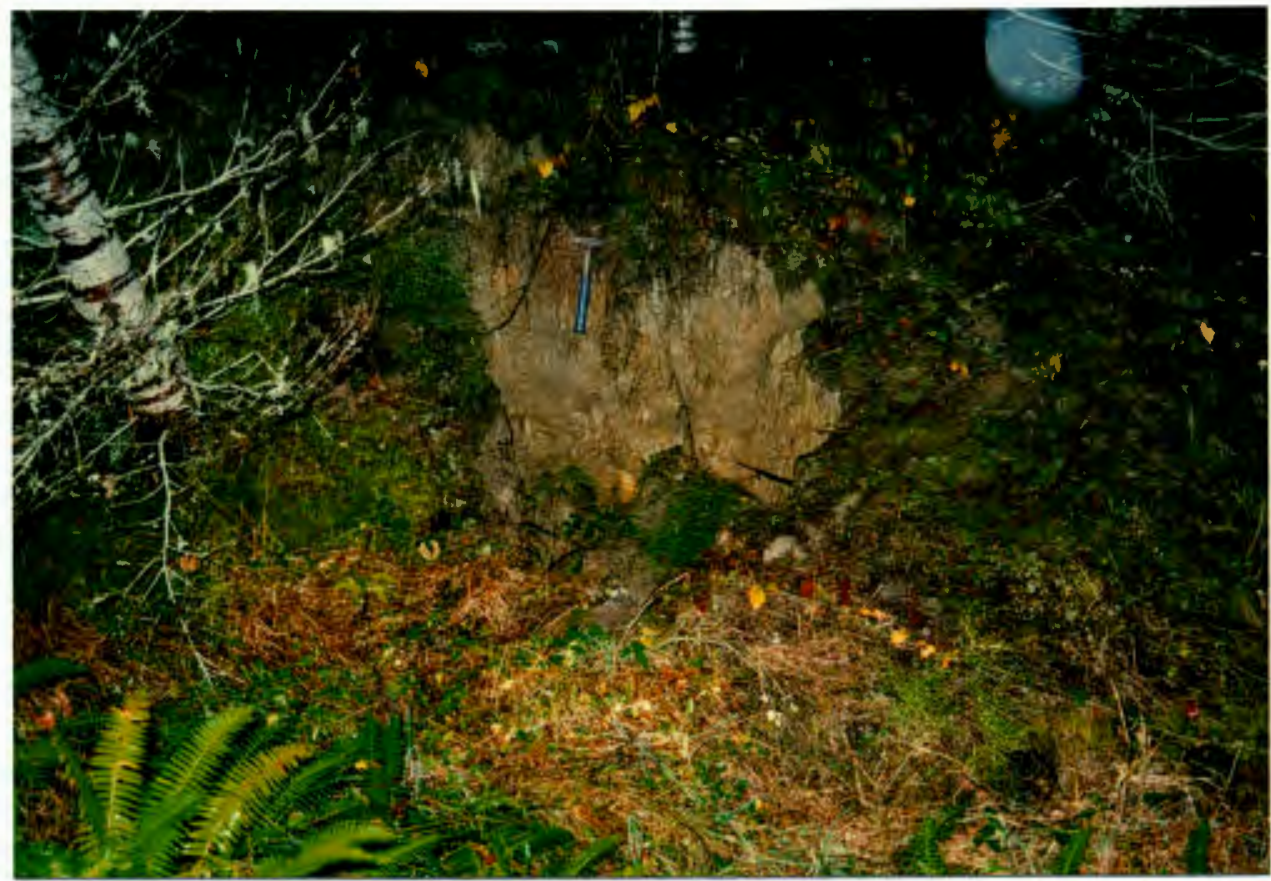

Figure 12. Soil Piping at Junction Earthflow. Note leaning tree and the saturated appearance of the exposed soil. Rock hammer for scale. 
the toe, where the A horizon is about 20 centimeters thick, the boundary between the $\mathrm{A}$ and C horizons is abrupt, with a change in moist color from 10YR $2 / 1$ to $10 \mathrm{YR} 6 / 1$. In contrast, the depth of the A horizon at the toe appears to equal the entire thickness of the lobe (Figure 13). The typical soil profile for Junction earthflow consists of a dark and relatively loose $\mathrm{A}$ horizon, over a dense $\mathrm{C}$ horizon that is in a reduced state for much of the year (Figure 14) The soil may be mottled at depths as shallow as 15 centimeters (Figure 15).

Seeps and springs, visible in several locations at the base of toe, correspond with phreatic water levels at the road and along the body of the earthflow (USFS 1990b). These nominal drainages discharge water continuously during the winter, but are matched or exceeded by recharge from sources above the road. The presence of seeps and springs suggests that water moves freely through the earthflow, and drained conditions have begun to develop. As this happens, movement rates may decrease.

From the toe of the active lobe, the larger, more stable earthflow lobe extends to the west and terminates above a terrace about 75 meters from the Clackamas River. The presence of this stable lobe is an indicator of past conditions. Its surface undulates gently and is marked by swamps and straight timber. Its toe is distinct because of its size, but unlike the active toe, which is nearly vertical in places, it slopes at a modest 30 degrees. The southwest edge of the toe has been partly eroded by a small stream, but there has been no return to activity because of this over-steepening.

\section{Monitoring \& Movement}

Because it causes ongoing damage to road 46 , Junction is one of the most extensively monitored earthflows in the area. In 1989, two inclinometers, six piezometers, and one rain gage were installed on the earthflow adjacent to the road. Four years of inclinometer 


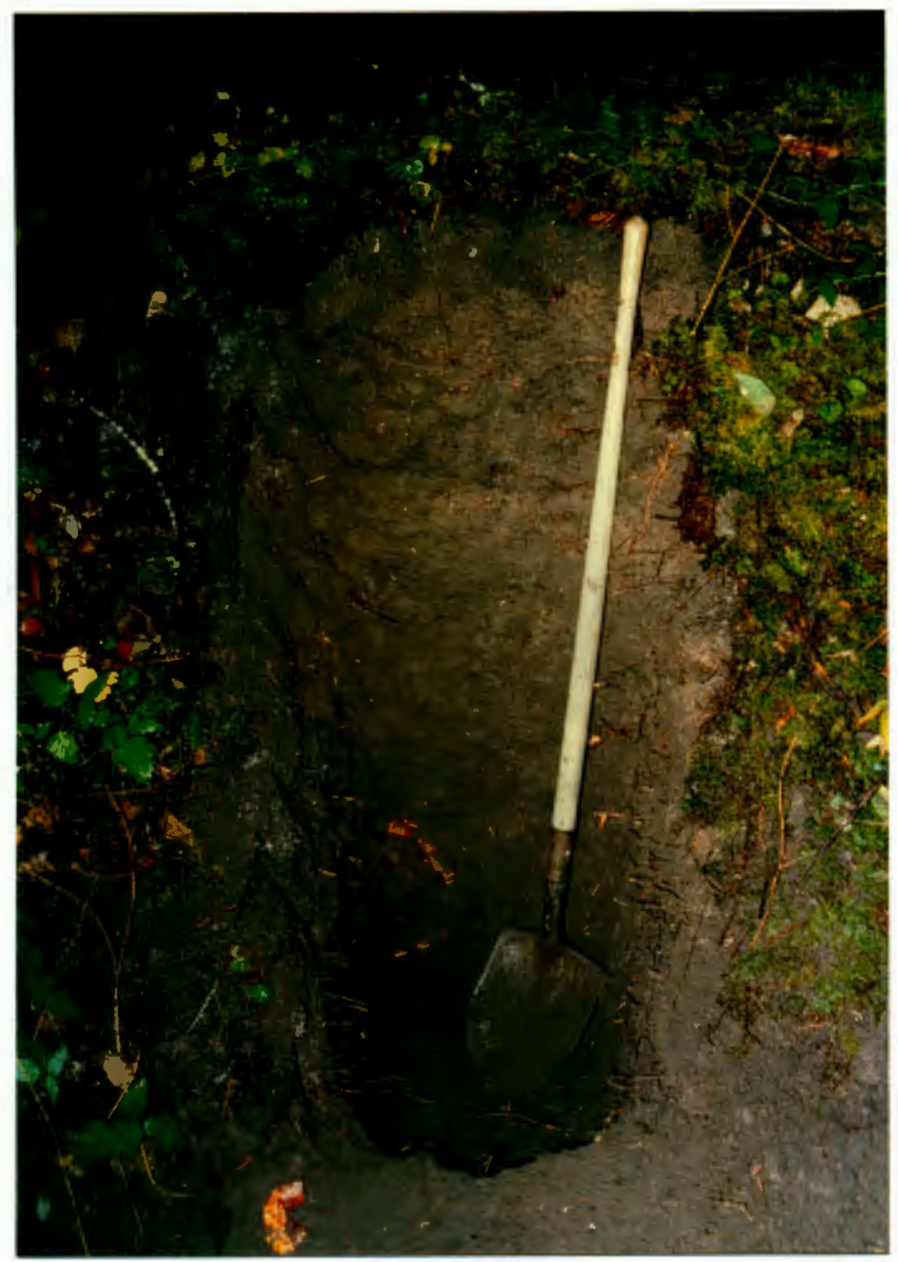

Figure 13. Exposed Toe of Junction Earthflow. Earthflow activity has caused the A horizon to become over-thickened by wrapping it around the front of the toe. Unweathered parent material occurs within one meter of the surface at nearby sites, though it is not visible here. Shovel for scale. 


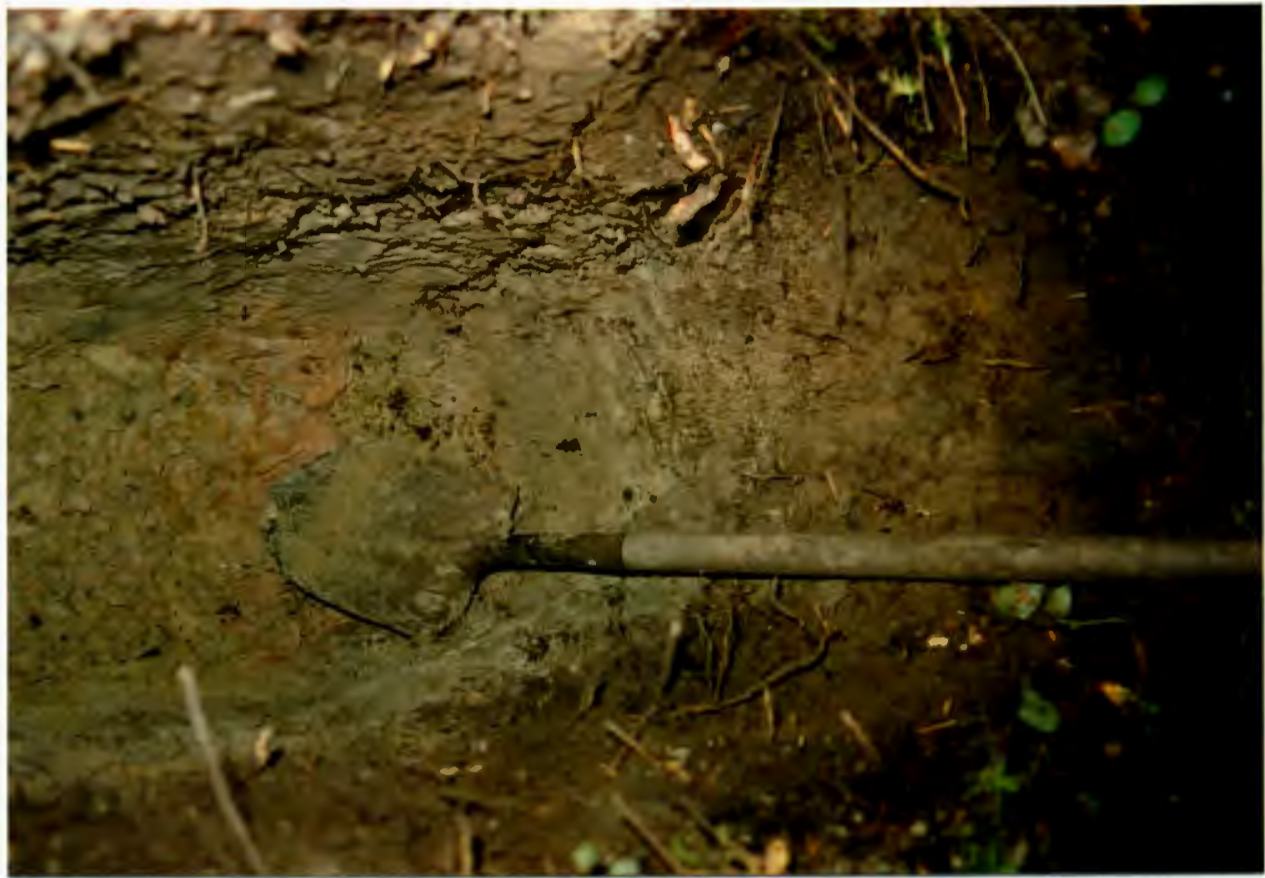

Eigure 14. Typical Junction earthflow soil profile. Note the reduced conditions.

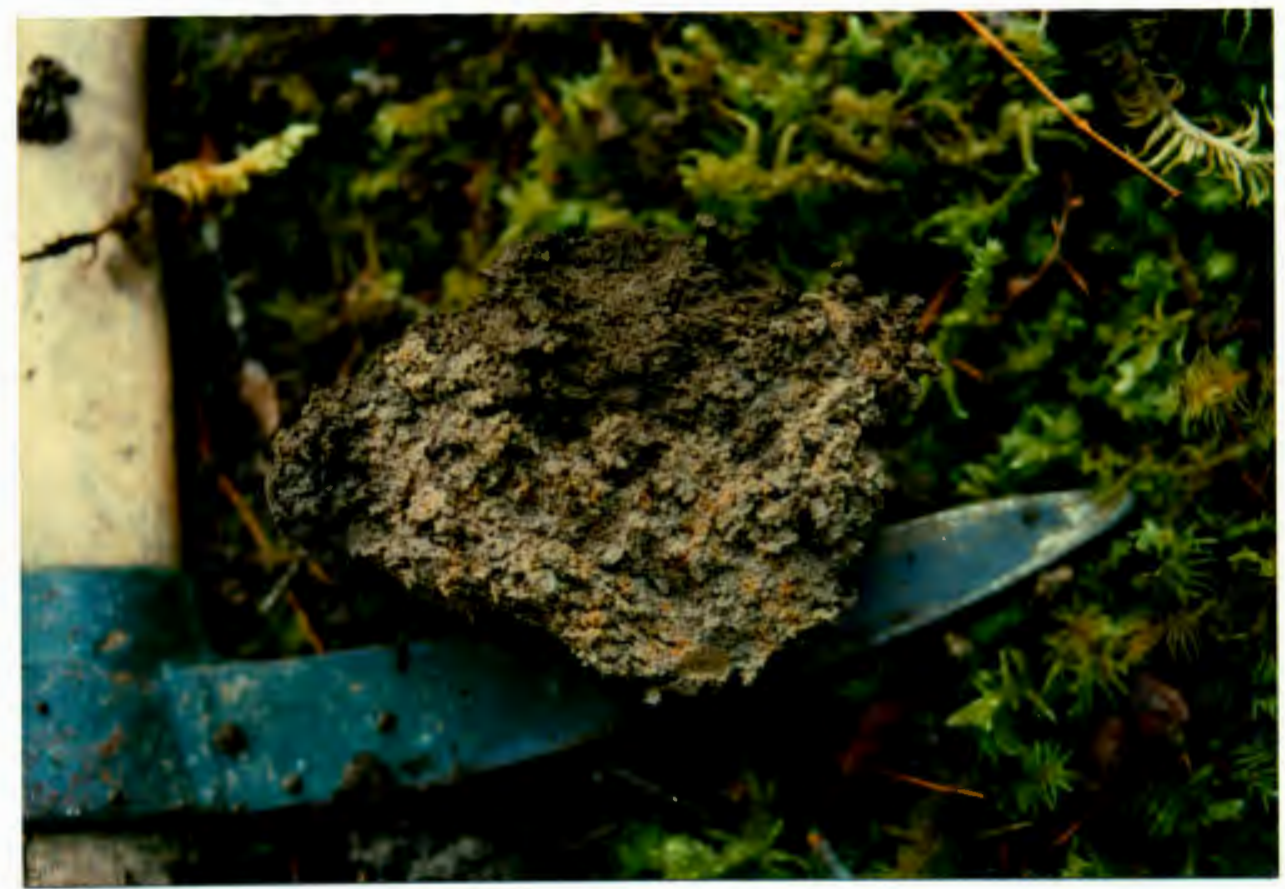

Figure 15. Mottled soil from Junction earthflow. 
data show that movement below the road averages about 2 centimeters per year, while vertical movement in the road prism may be several times this amount. In addition, as a result of earthflow movement, the road alignment has shifted noticeably to the west. Inclinometer readings show accelerated movement in 1991, possibly because road cracks from the previous season were not patched, allowing water direct access to the meter-thick shear zone. The cracks were patched in summer of 1991 and movement rates returned to normal. The depth of the shear zone is inconsistent and, according to inclinometer data, varies between five and seven meters. Since the inclinometers are separated by approximately 30 meters, it is not clear whether there is a single shear zone or several.

Two aquifers, one confined and one unconfined, were encountered when the inclinometers and piezometers were installed. Phreatic levels are generally quite high, and artesian conditions have been noted nearby. Piezometer and rain gage data indicate that the confined aquifer responds only to long-term trends in precipitation. In contrast, the unconfined aquifer responds quickly to rainfall, but the response varies depending on the amount of water already present in the system. At the onset of the wet season, when this antecedent water is at a minimum, several days elapse before a rise in water level can be detected. Conversely, during the wet season, when water levels are high, groundwater response to rainfall is immediate. These early fluctuations in the water table may be reflected in earthflow activity.

A stability analysis was performed by Forest Service personnel on a section of the earthflow that is crossed by road 46 (USFS 1990b). In the "natural state," the calculated factor of safety is approximately 1.07 , indicating that variations in pore water pressure are the principle controls on this value and related movement. Movement rates and precipitation show moderate correlation on an annual basis, but since continuous inclinometer readings are unavailable it is difficult to interpret the response of the earthflow 
to individual precipitation events. The commonly-held belief is that earthflow movement is controlled by seasonal moisture trends rather than single-storm events (Sidle 1985). Work in New Zealand, however, indicates that, at least to some degree, surficial movement is influenced by single storms (Phillips pers. comm. 1993).

\section{Thixotropy}

Some of the soils on Junction, particularly those with the highest clay contents, are thixotropic; that is, on disturbance, their consistency changes from a semi-solid to a viscous liquid with no added water (Yong and Warkentin 1975). Soils which exhibit thixotropy are generally more sensitive and prone to instability than soils which do not. This property can be observed by placing a soil sample whose water content is near its liquid limit into a beaker or test tube. When the sample has been undisturbed for some time, it will be in a semi-solid state and will withstand some amount of stress without deforming (Figure 16). When the sample is subsequently disturbed (Figure 17), it will lose shear strength and behave like a viscous fluid (Figure 18). Although residual strength will increase with "rest-hardening," peak shear strength is not likely to return, as shown by the curve in Figure 19 (Das 1990). Because of persistent earthflow activity, it is difficult to tell how much rest-hardening has occurred for Junction soils. The important point is that the shear strengths of these soils are lower than those of undisturbed soils even after resthardening has occurred.

\section{COLLOWASH EARTHFLOW}

\section{Morphology}

The Collowash earthflow is located about five kilometers south of Junction earthflow, in a separate earthflow complex (Figure 20). Like Junction, the 


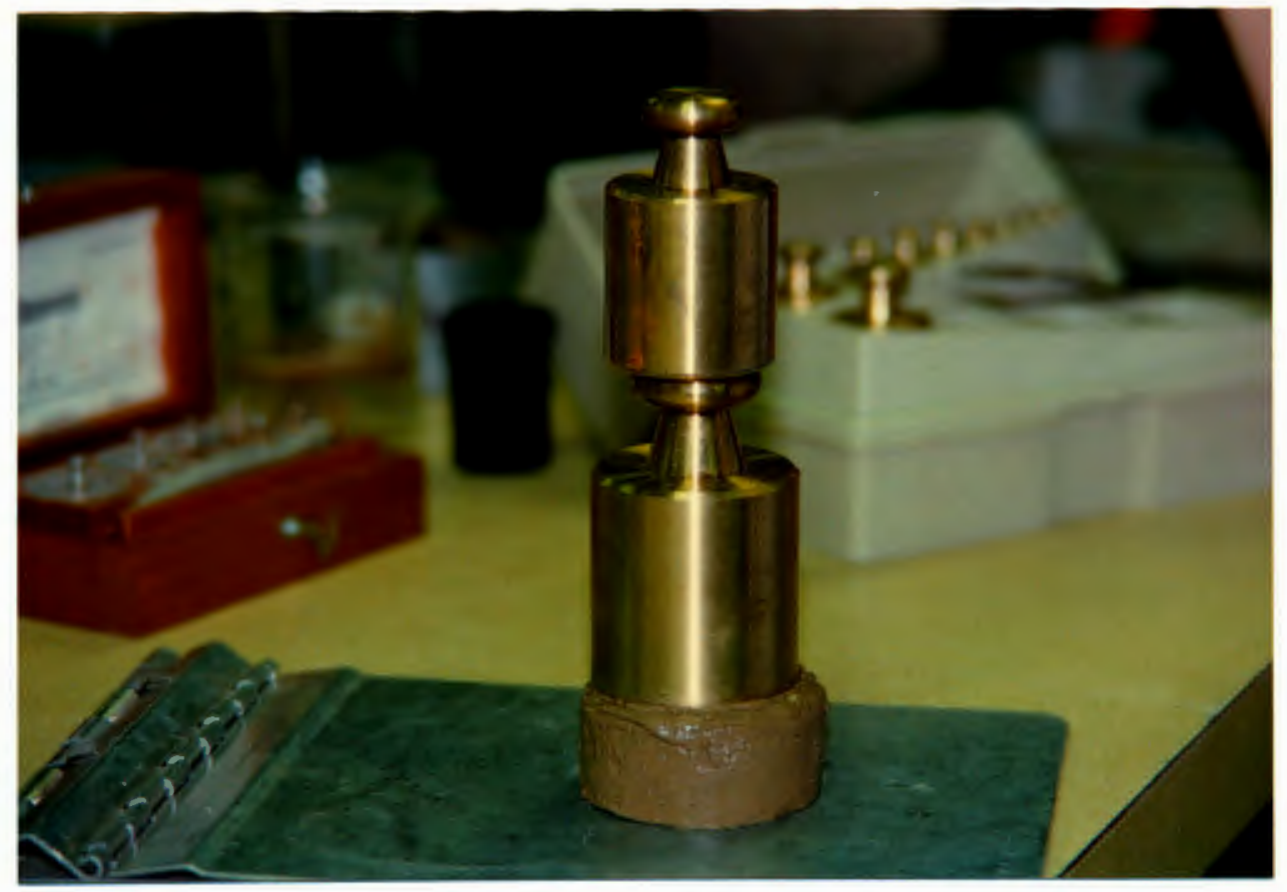

Figure 16. Thixotropic soil supporting $1.5 \mathrm{~kg}$ weight.

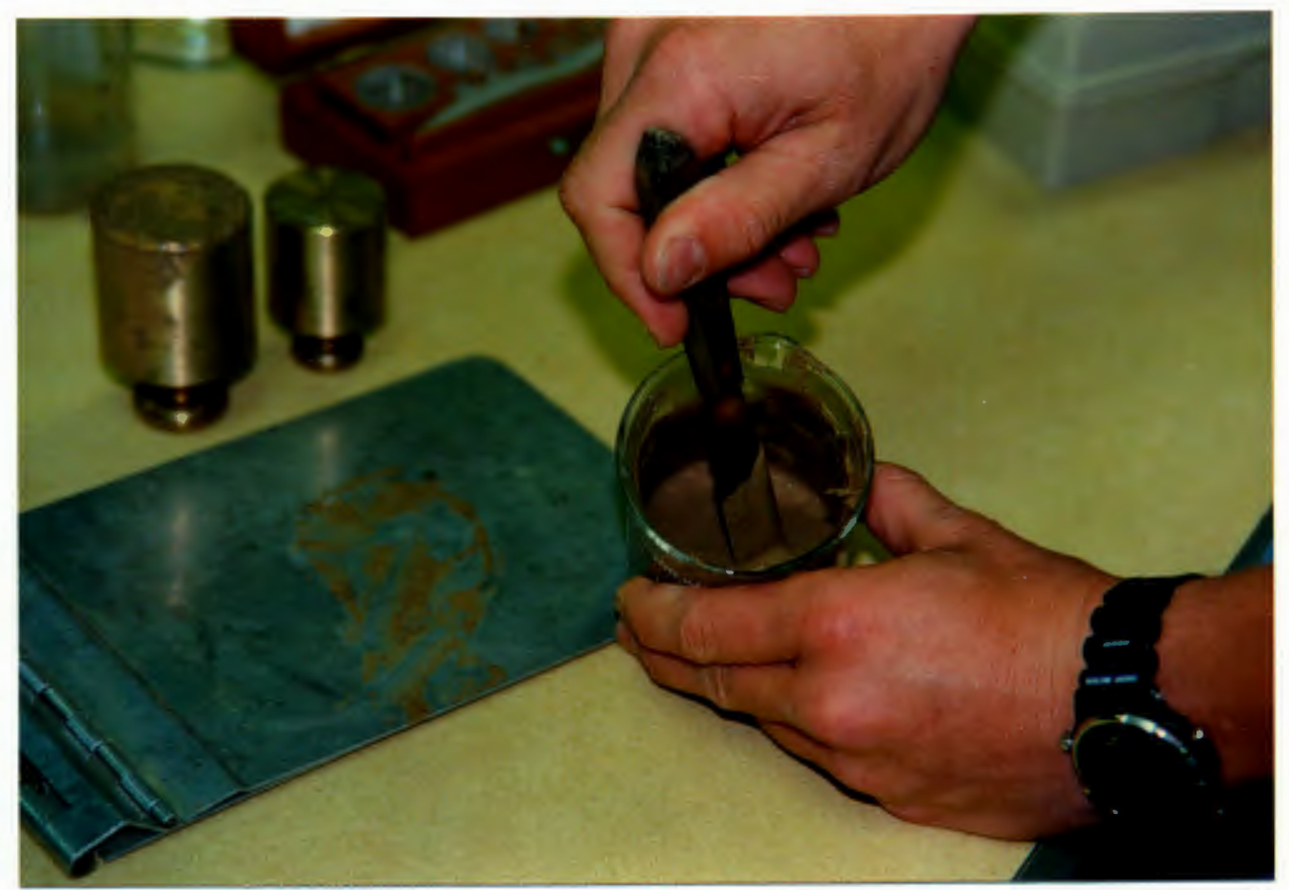

Figure 17. Remolding of thixotropic soil. 


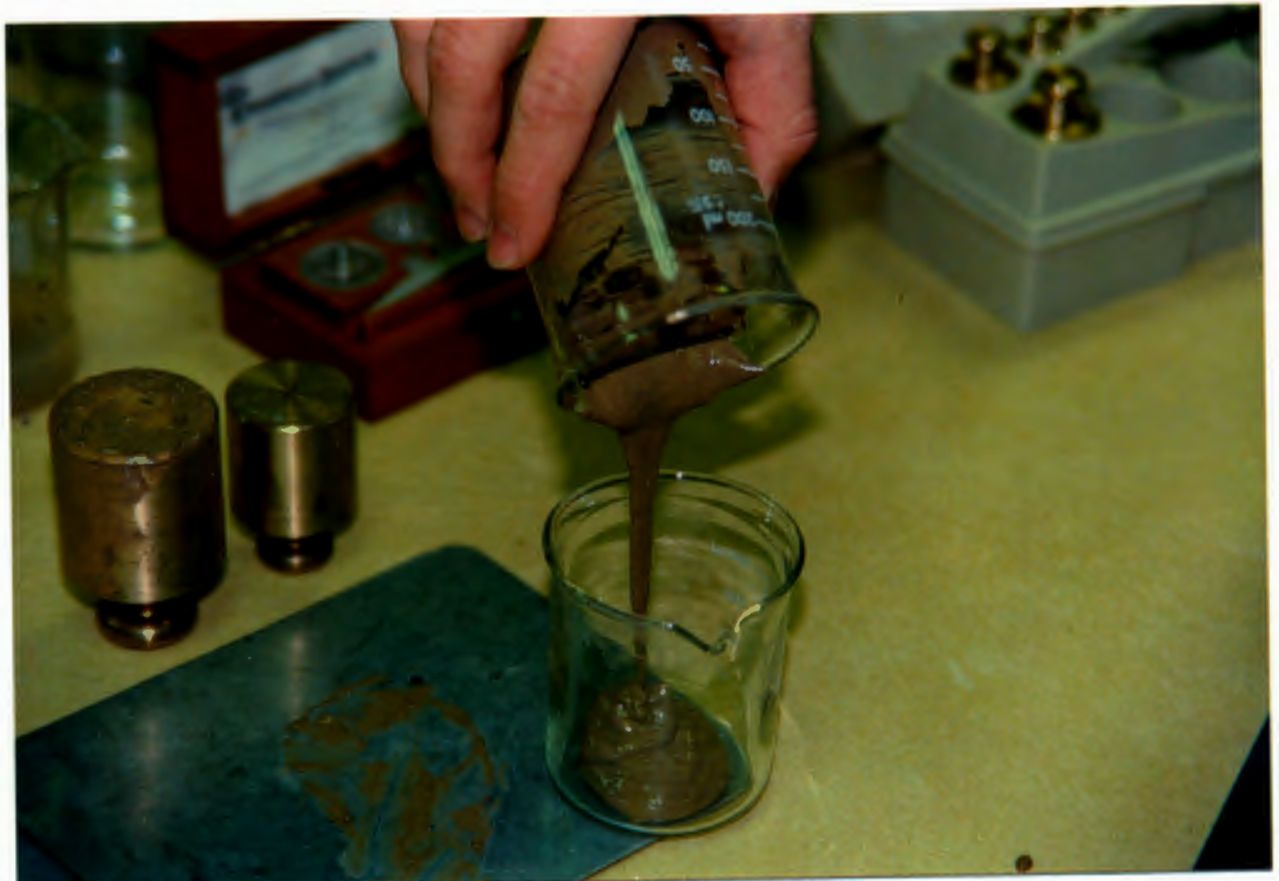

Figure 18. Thixotropic Soil in Remolded State. 


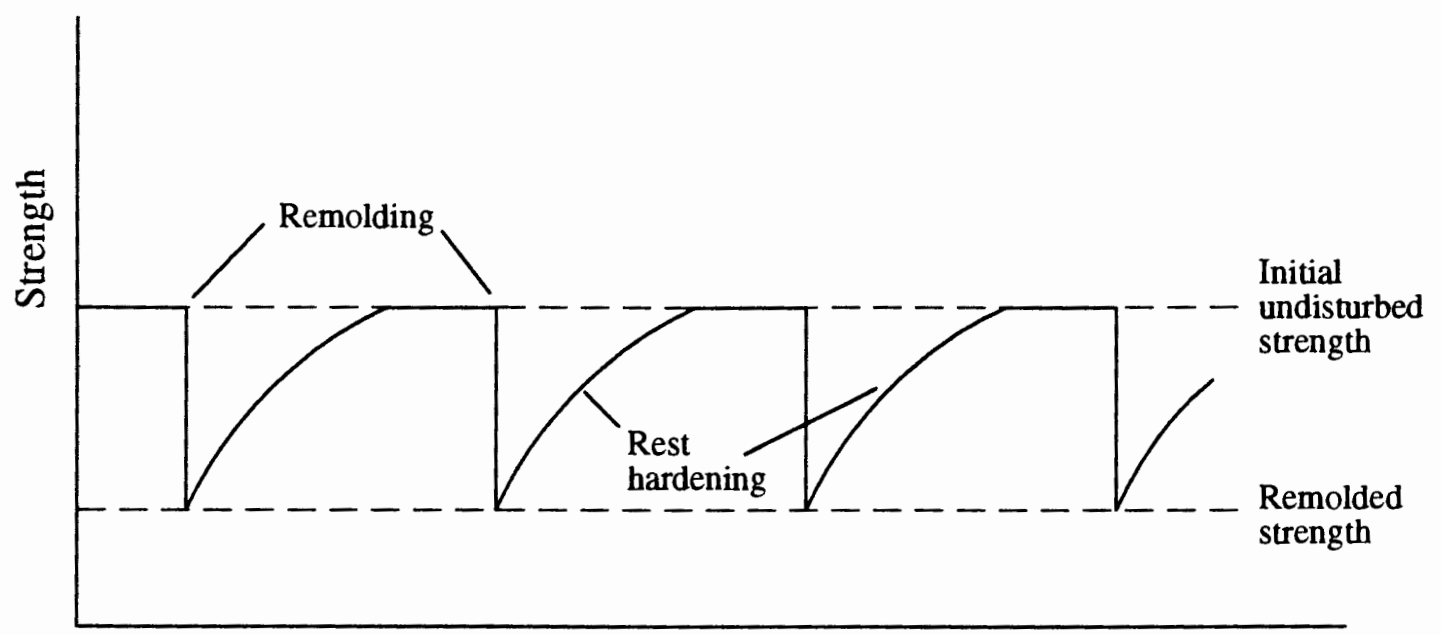

a.

Time

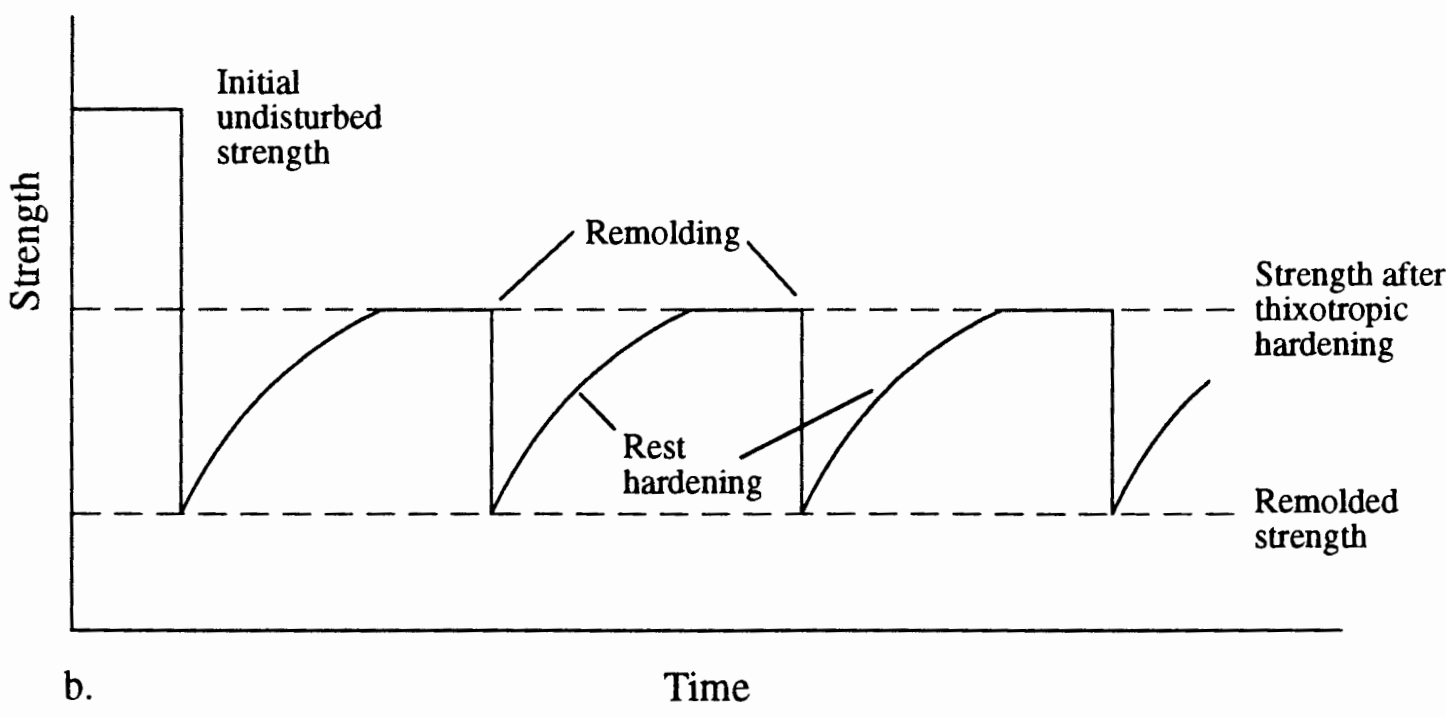

Figure 19. Thixotropic Response to Disturbance. Behavior of thixotropic (a) and partly thixotropoic (b) material upon remolding. Some soils from active earthflows are partly thixotropic and may be at their remolded strength. Soils from stabilized deposits may also be partly thixotropic, but these have greater strength due to "rest-hardening." (From Das 1990) 

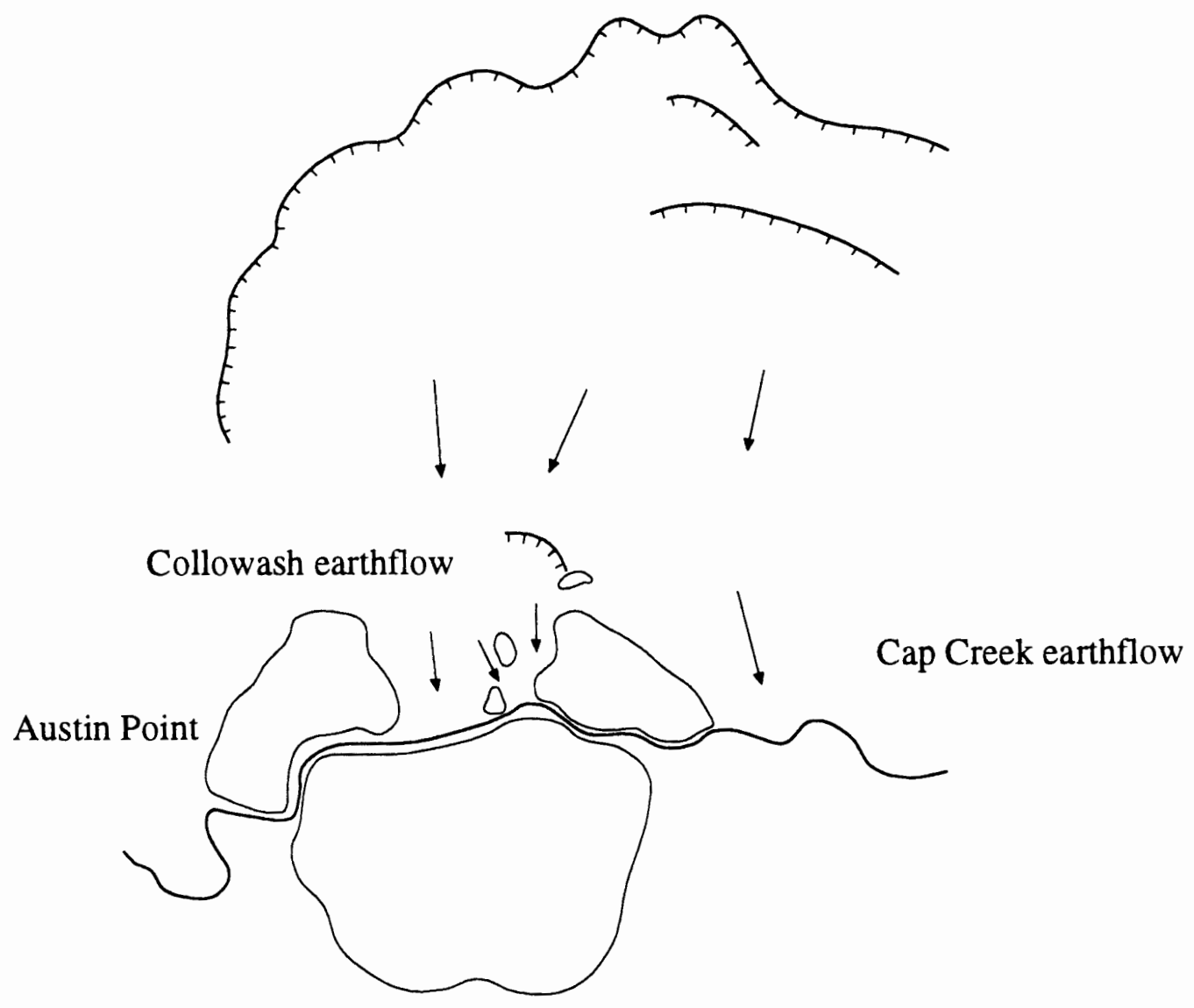

Figure 20. Collowash earthflow complex. 
upper boundary of this earthflow complex is the scarp of a Pleistocene landslide, though here the scarp is somewhat curvilinear and less distinct (Figure 21). In comparison to Junction, the slope angle of Collowash earthflow is approximately 4 degrees higher, and deviations from the mean angle are as much as 30 degrees. Despite steeper slopes, sag ponds are more prevalent on Collowash earthflow than Junction. Another important difference between these two earthflows is that Collowash earthflow undergoes continuous toe erosion. In addition, Sluice Creek, a tributary of the Collowash River, transects the body of the earthflow and has created a secondary toe that is highly unstable (Figure 22). Much of the sediment removed from Collowash earthflow is transported from its interior by Sluice Creek (Figure 23).

The active portion of the earthflow is easily delineated. Its toe adjoins the Collowash River along a 150 meter reach and its upper boundary is marked by multiple scarps and an overall appearance of havoc. The margins of the earthflow are evidenced by elongated boundary shear zones. When active and fresh, these zones are no more than paper-thin, slickensided cracks. Older, less active shear surfaces appear as long, narrow depressions which, because they represent an efficient template for drainage, have been expanded by flowing water. Today, some marginal boundaries of the Collowash are more than one meter wide and carry water perennially; others are narrow and slickensided.

Movement rates of the Collowash are relatively high, and its landforms are developed accordingly. All of the classic features associated with active earthflows are found: lobate forms, tension cracks, shear surfaces, headscarps, sag ponds, and tilted trees. Like many large earthflows, the Collowash is comprised of an assemblage of discrete blocks of debris which slip and flow past one another at different rates. Within the active portion of the slide, differential movement has created well-developed tension cracks and boundary shear surfaces (Figure 24). Tension cracks are best developed above headscarps where the slide 


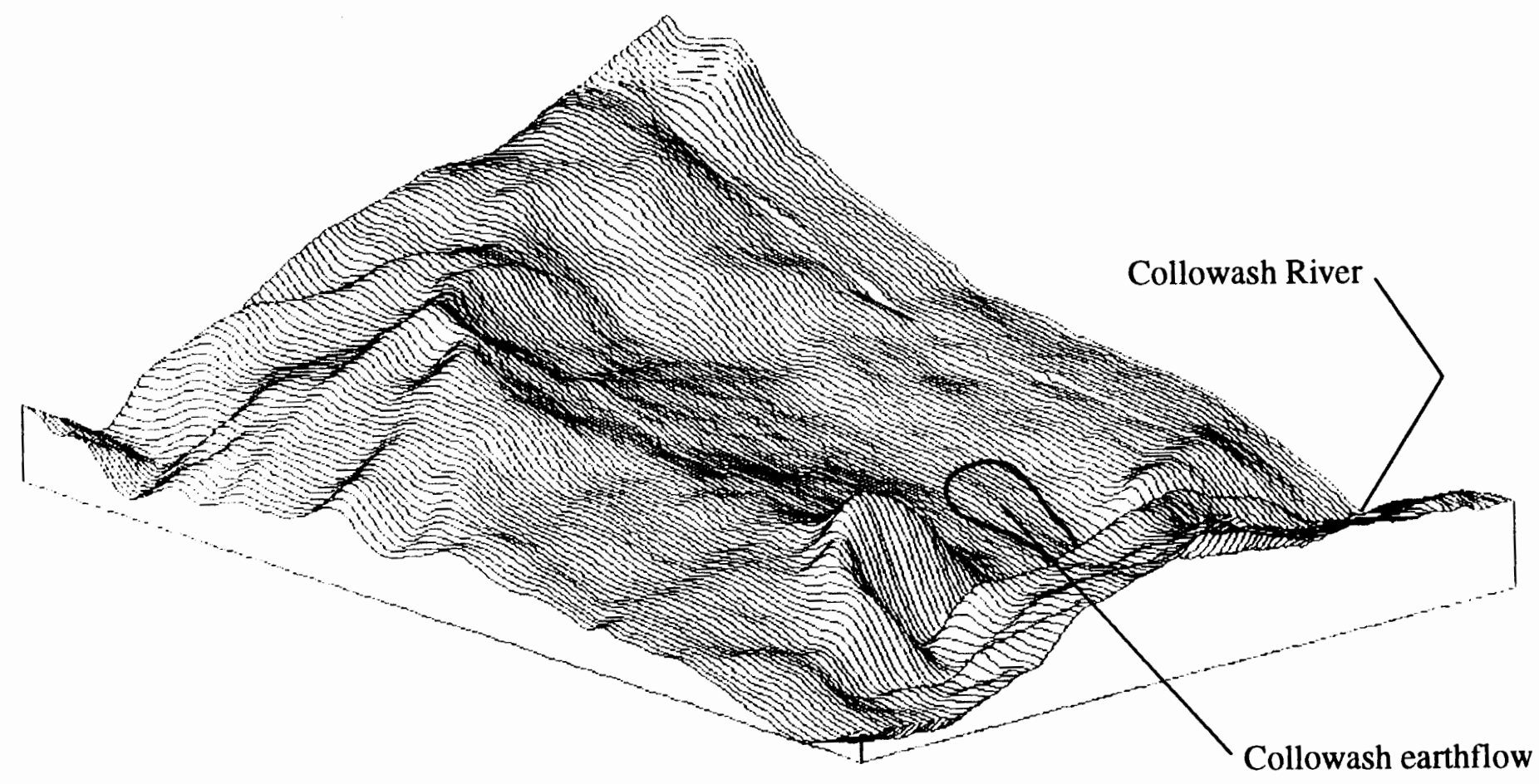

Figure 21. Collowash Earthflow Complex. The intrusion in the foreground is Austin Point. 


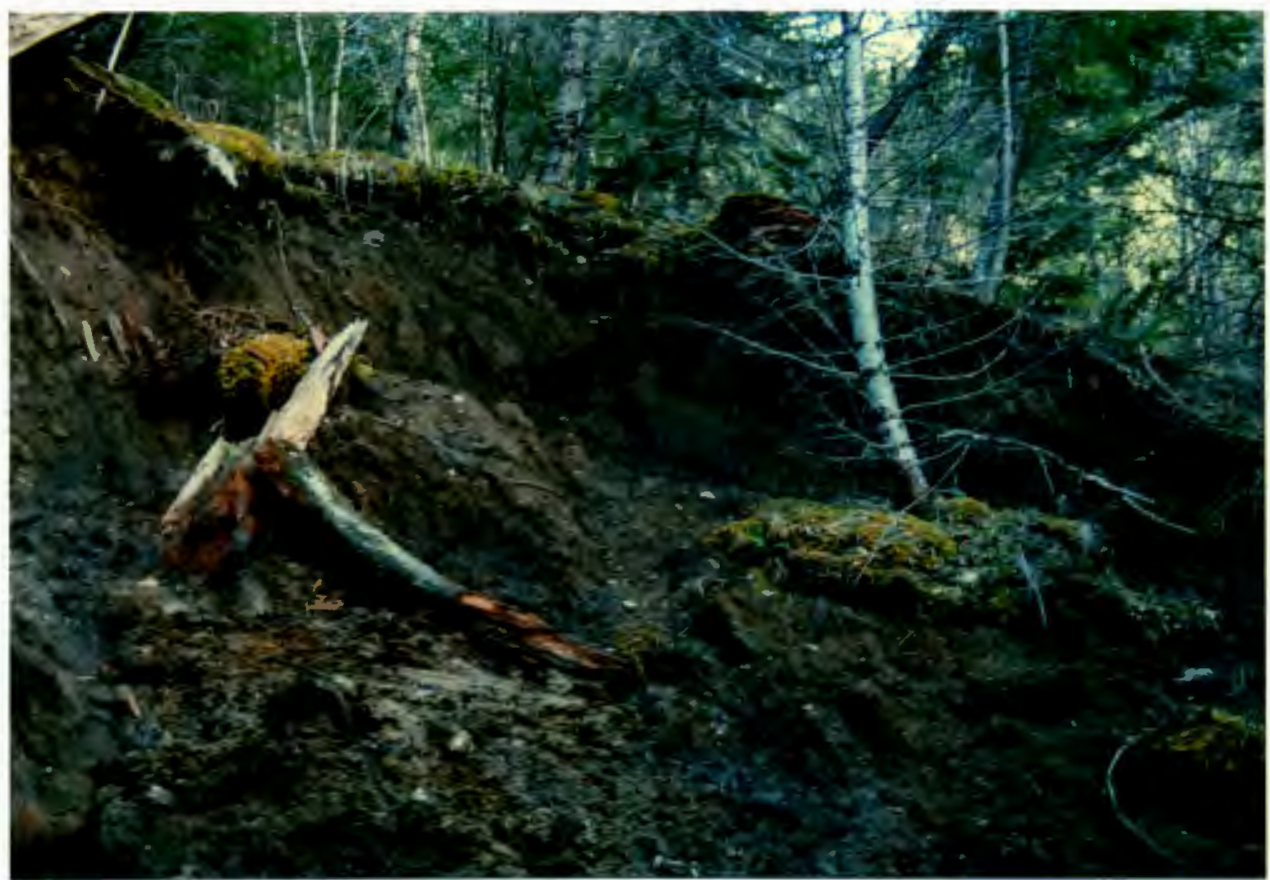

Figure 22. Secondary earthflow toe. Note intact root wad on tree at center.

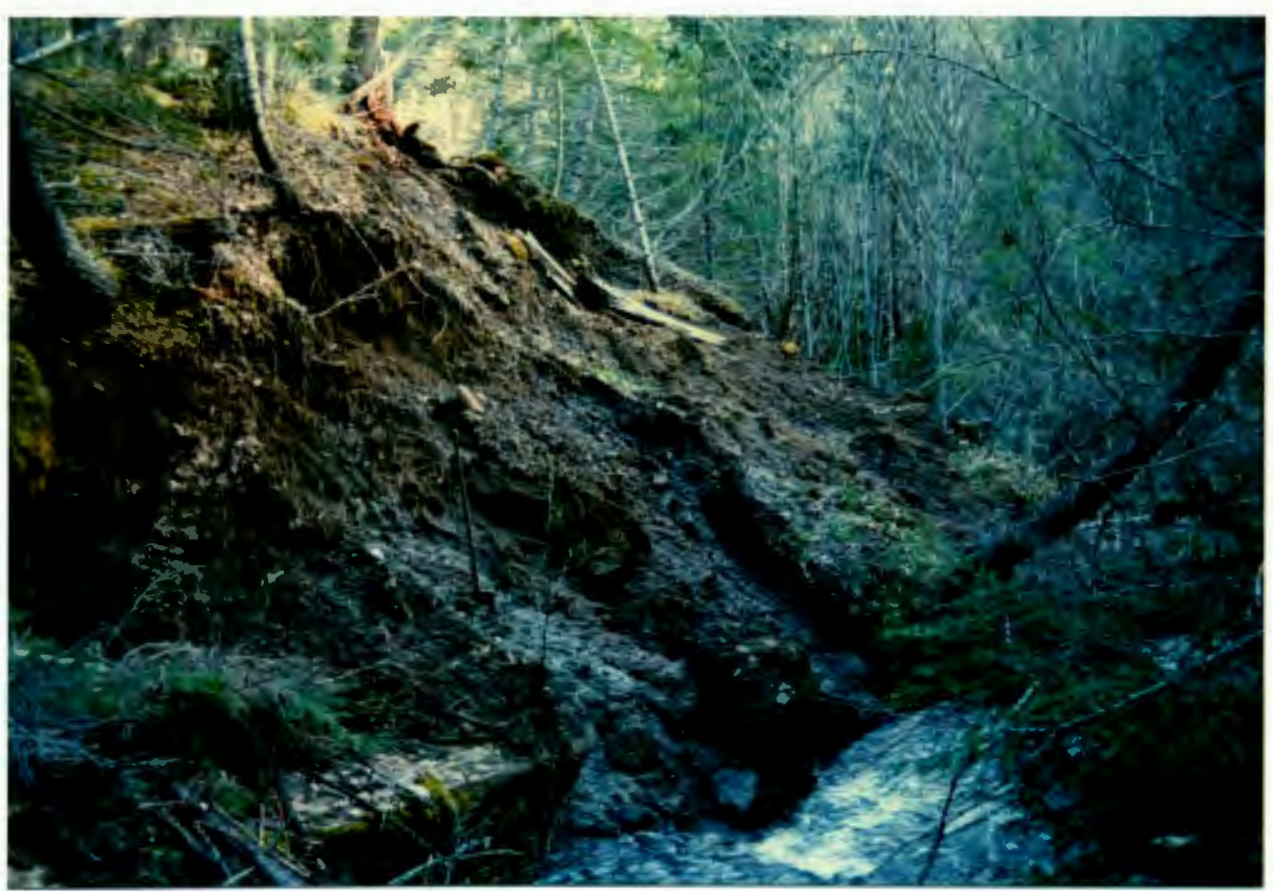

Figure 23. Sluice Creek. Cause of the secondary toe in the previous figure. 


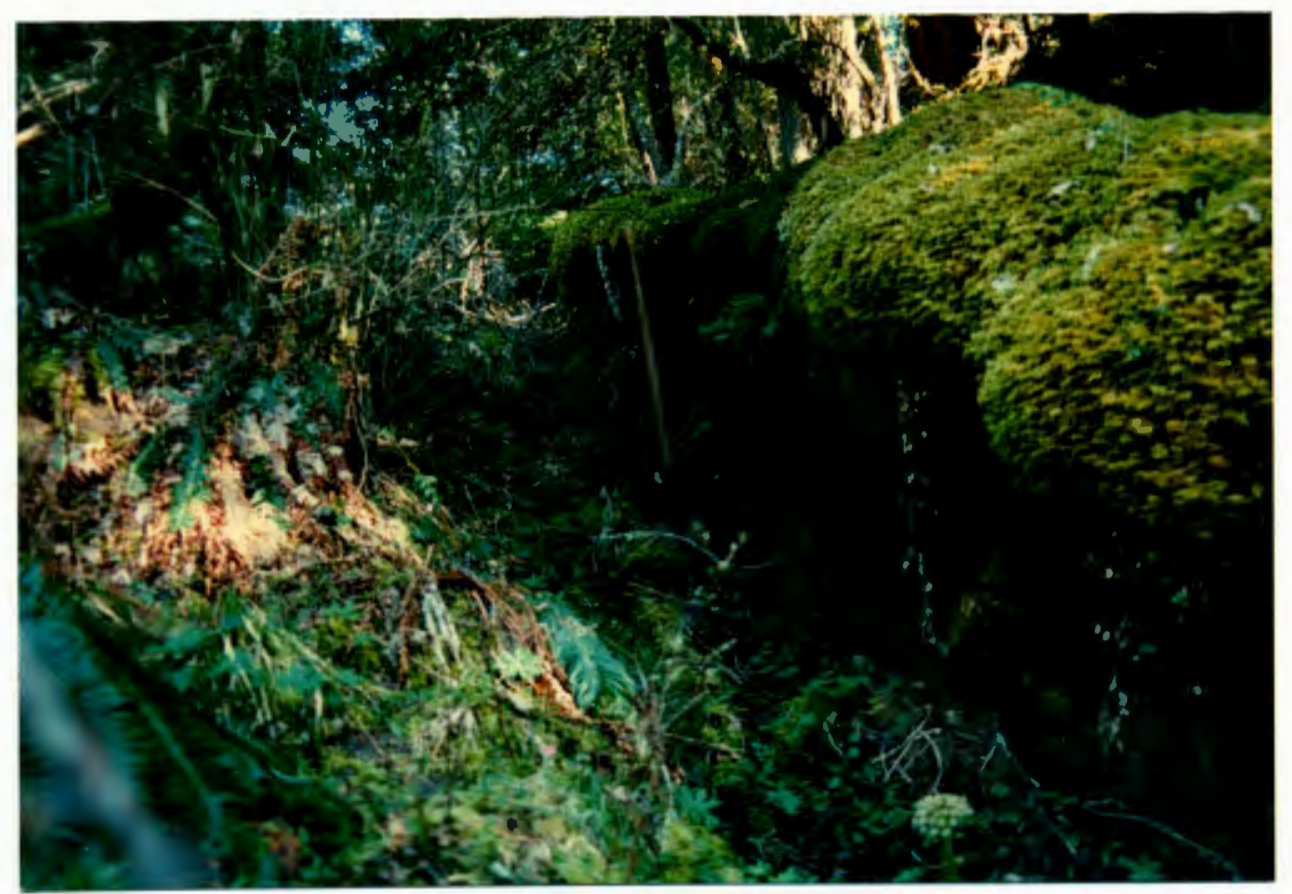

Figure 24. Boundary shear zone. This abrupt slope break marks the marginal boundary between an active portion of the Collowash earthflow and stable ground. The earthflow is on the left and moving toward the camera. The difference in slope heights represents the amount of earthflow material removed. Note shovel for scale. 
mass is separating from the more stable main body. The dimensions of these cracks vary, but depths and widths often exceed one meter. In many places tree roots span this distance and may be stretched taut between the soil masses (Figure 25). Similarly, where tension cracks intersect tree trunks, the trunks are often split vertically for several meters along their length (Figure 26). These examples illustrate how root cohesion increases the strength of shallow soils. In New Zealand, additions of root strength have been implicated with modifying velocity profiles of rapidly-moving earthflows by either resisting or promoting surface movement (Marden et al. 1992; Zhang et al., 1993). The data needed to confirm such behavior for the Collowash were unavailable, but the similarities it holds with the earthflows studied in New Zealand indicate their behavior might be analogous (Phillips, pers. comm., 1993).

The toe of the Collowash earthflow is the site of vigorous geomorphic activity which is caused by the complimentary effects of earthflow advance and river erosion. Slumps, debris slides, and debris flows are common along the toe, particularly in the wet winter months when the river stage is high and soils are saturated (Figure 27). Although the earthflow enables sediment loading to occur, the actual delivery of sediment to streams depends on discrete failures, which deserve much of the credit (or blame) for completing the cycle in such an expeditious fashion.

\section{Monitoring \& Movement}

Monitoring of the Collowash earthflow began around 1980. The Forest Service project files indicate monitoring was to be extensive, utilizing stake lines, stake arrays, groundwater wells, and several inclinometers. Regrettably, only one inclinometer, one stake line, and one stake array were installed. The project files contain only the initial inclinometer reading and stake line and array readings for roughly one year of movement. 


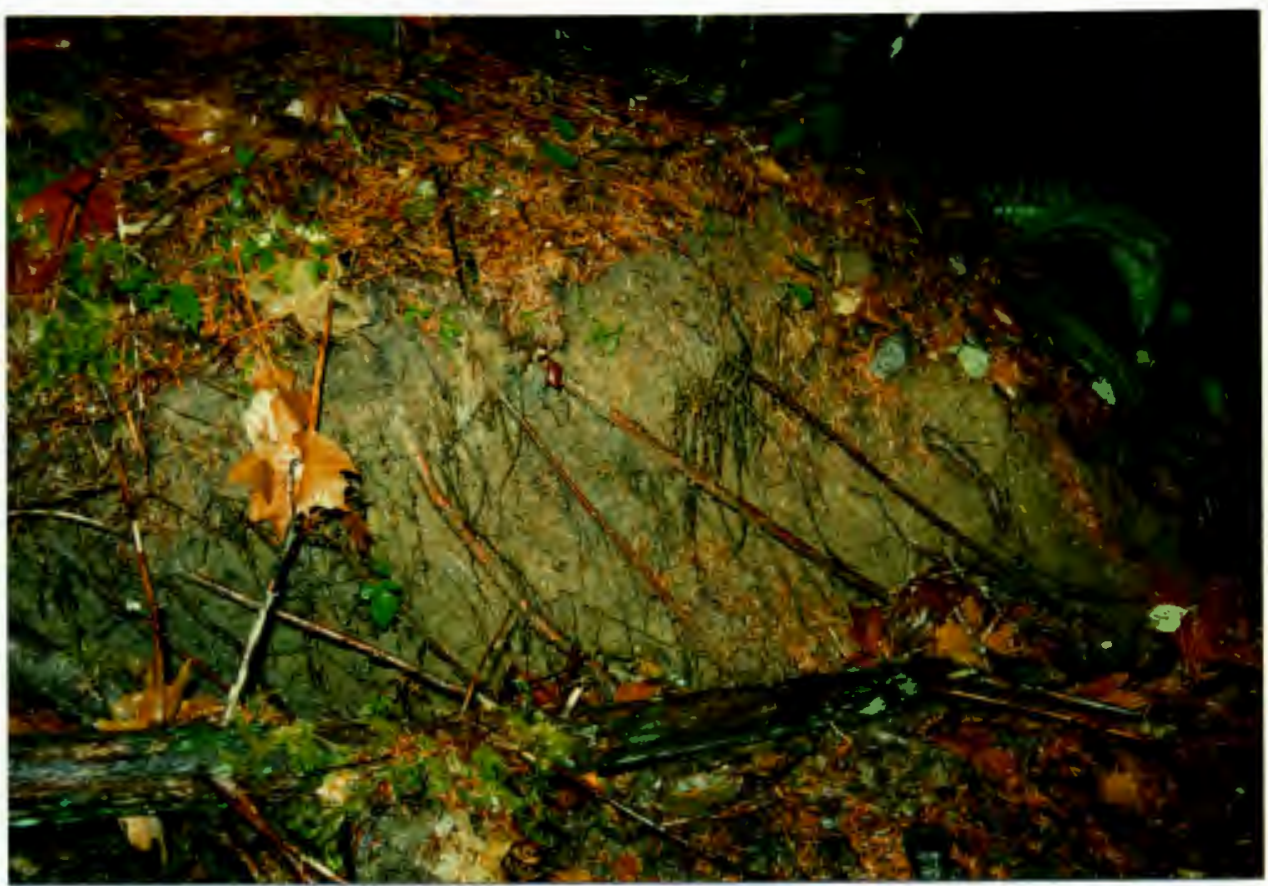

Figure 25. Stretched roots. These roots span a large tension crack above a scarp.

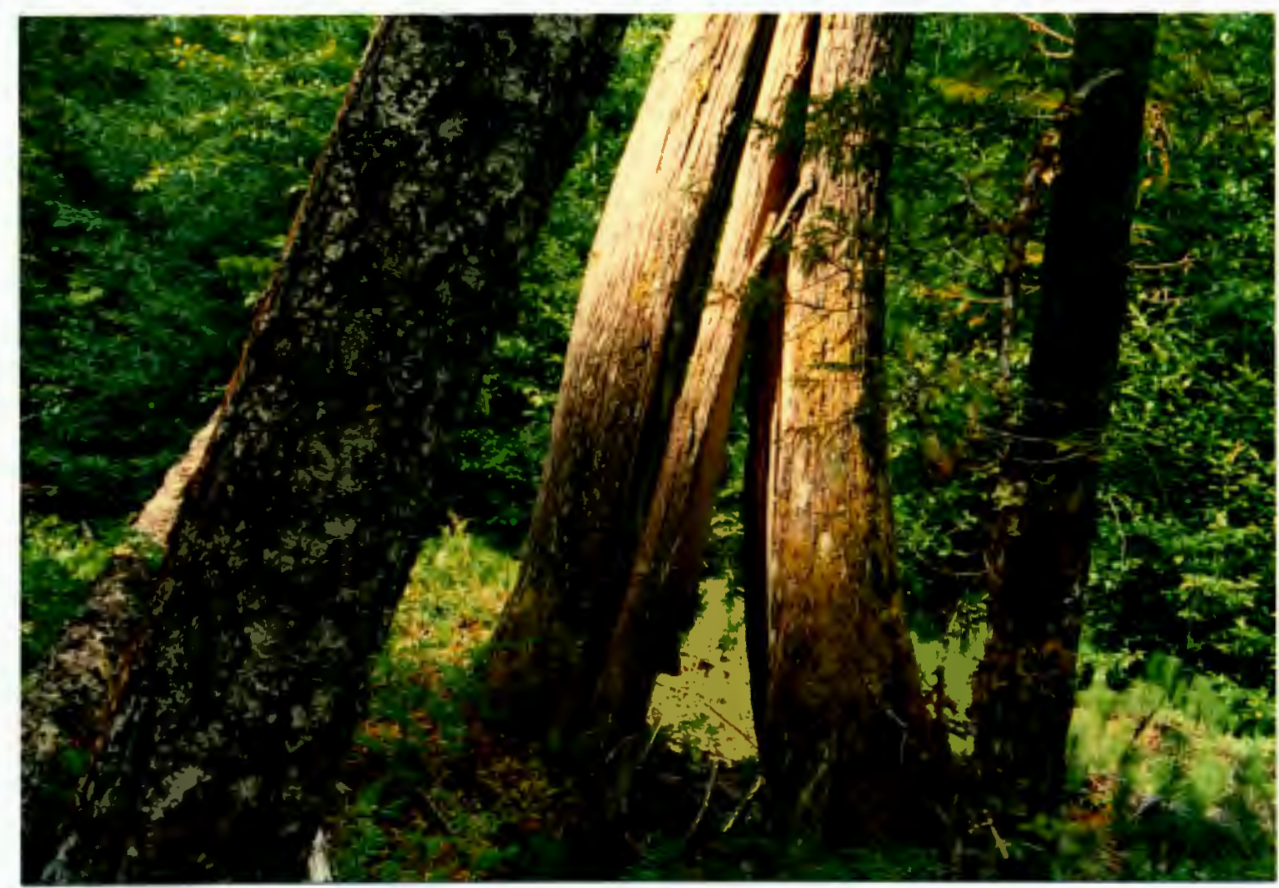

Figure 26. Split tree. Direction of earthflow movement is to the right. 


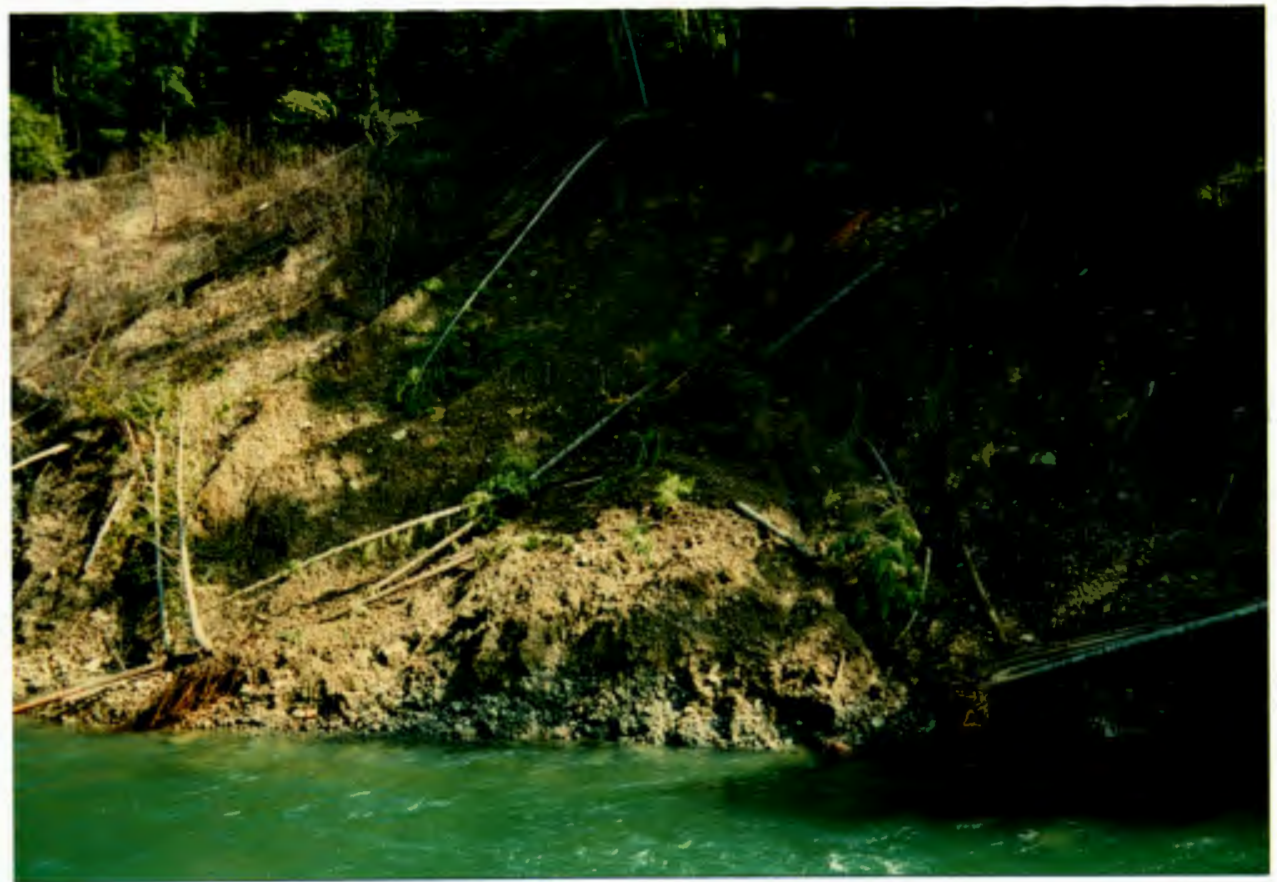

Figure 27. Slope failure in the toe of the Collowash earthflow. This picture was taken two months after the March of 1993 failure. A large percentage of the material had already been removed during times of peak flow. 
The inclinometer was rendered useless after only a few years because its limited flexibility could not withstand the rapid movement. If additional readings had been taken during this time, they have since been lost or misplaced.

The stake line, which spanned approximately 75 meters, consisted of two stable survey points and seven plastic stakes oriented normal to the direction of movement. After one year, measurements of the stakes revealed surface movement ranging from 0.6 meters to 3.8 meters, though not all movement was directly downslope. Maximum downslope displacement was 2.3 meters. these stakes have not been located and probably are no longer intact. A second stake line was installed in August of 1993, but measurements of this line have not yet been taken.

The stake array was installed in November of 1981 and consisted of four plastic stakes arranged in a square, with two stakes on either side of a boundary shear margin. Thus, two stakes were on active earthflow; two were on a stable bedrock island. Measurements of the stake array taken after a single winter indicated that 4.1 meters of surface displacement had occurred. This was the only measurement taken until December of 1992, when, with the help of two field companions, I discovered the stake array. Approximately eleven years after they had been installed, the stakes were now separated by some 25 meters, indicating a annual average displacement of 2.3 meters each year. In August of 1993, the stakes were remeasured. The upper stakes were separated by an additional 2.4 meters, while the lower stakes by only 1.1 meters. One possible explanation for this discrepancy involves the microtopography of the earthflow's surface. A small monoclinal dip is present where the lower stake is now located. As the earthflow travels down this steeper surface, the slide mass rotates forward and accelerates. At the bottom of the monocline, where the gradient is lower, the slide mass rotates back and returns to its previous velocity. The lower stake is tilted forward, but is near the bottom of the steep 
surface, implying there was a period of forward-tilting and acceleration which now gives way to backward-tilting and slower movement, possibly due to compression at the base of this minor slope. Total movement through the summer of 1994 was slightly less, at about 1.5 meters, probably a result of less precipitation throughout the winter months.

\section{ALDER EARTHFLOW DEPOSIT}

\section{Morphology}

Alder earthflow occupies the point of a narrow ridge and is situated to the south of a major tributary of the Clackamas River named the Oak Grove Fork (Figure 11). The ridge consists of Beds of Bull Creek but is capped by Grande Ronde Basalt and underlain by Andesite of Nohorn Creek. The earthflow adjoins the river along a reach approximately 100 meters in length. Over the majority of this distance, the toe of the earthflow rises abruptly some 10 to 15 meters above the river. Locally, the toe-slope is quite steep, as much as 35 degrees where slumping has occurred, and 55 degrees where river erosion and undercutting is prevalent. At two locations along the earthflow-river junction, small tributary streams originating on the body of the earthflow have eroded the toe-slope, resulting in a graded transition from earthflow surface to river.

Two types of slope movements commonly occur at the toe: slumping and planar debris sliding. Slumps tend to originate at the crest of the toe and pass through the shoulder of the slope. Typically, their surface of rupture is several meters above the river, implying that slumping is unrelated to undercutting by the Oak Grove Fork. In contrast, undercutting has a strong influence over planar debris slides which frequently occur in the cut-bank positions along the river (Figure 28). Once a debris slide occurs, the unvegetated scar it creates is easily maintained by surface erosion or additional sliding caused by lateral cutting of the river. Therefore, debris slides are a more important source of sediment than 


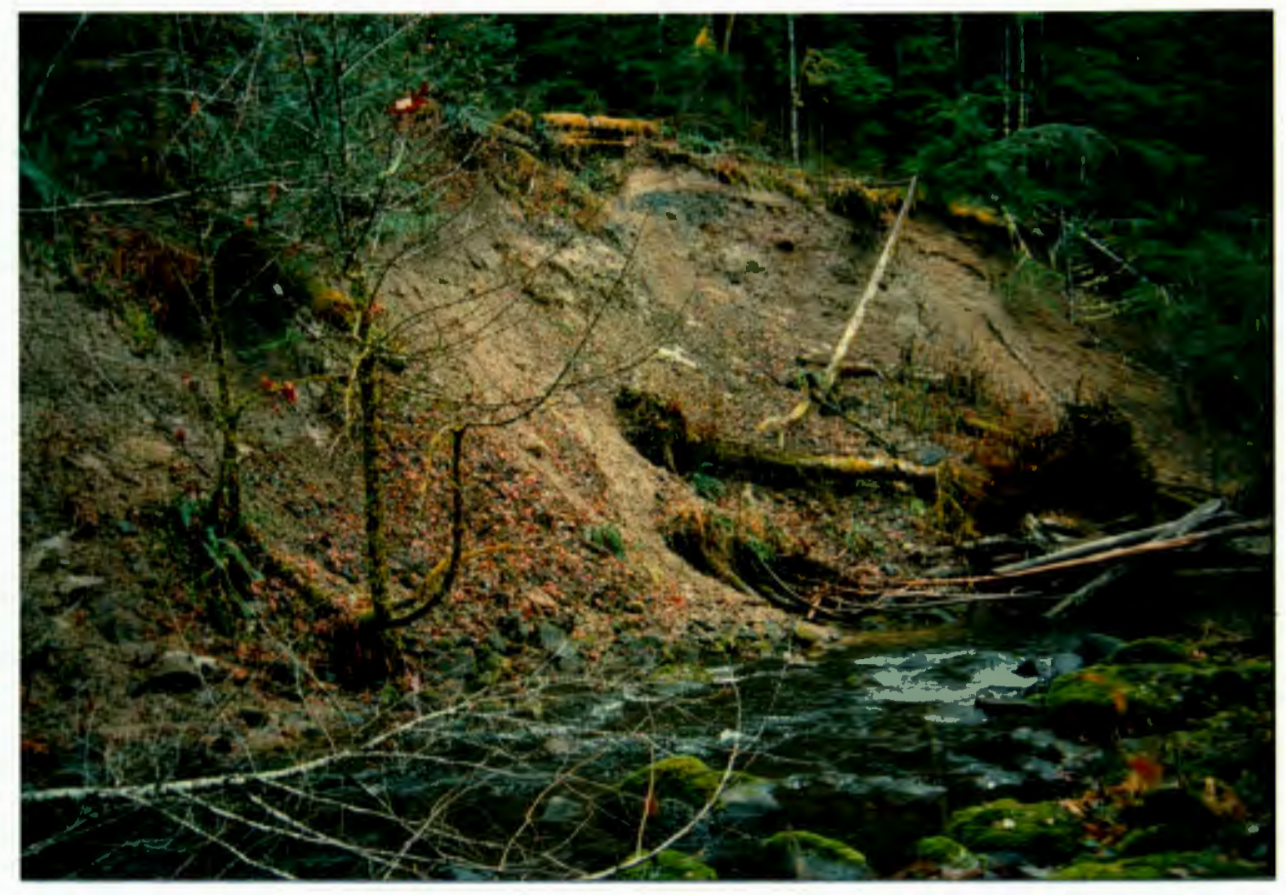

Eigure 28. Debris slide at the toe of Alder earthflow deposit. 
slumps, which are episodic and usually vegetated because their rotational movement preserves the vegetation cover.

The upper limit of Alder earthflow is the scarp of a Quaternary landslide which forms one side of a narrow interfluve. From head-wall scarp to toe crest, the earthflow is approximately 1200 meters in length, has a northwest aspect, and an average surface gradient of approximately 10 degrees. Its complex topography includes features typical of an earthflow deposit: well-worn hummocks, lobes dissected by streams, vegetated scarps, closed depressions, and abandoned levees.

The earthflow can be divided into an upper and lower section. The lower section is about 150 meters wide and is laterally confined by two discontinuous bedrock ridges. Figure 30 (plan map) shows that the earthflow intersects these ridges at an oblique angle and responds with a dog-leg turn to the north. At the apex of this turn are several minor scarps which are probably the combined result of an increase in slope gradient and acceleration of the slide mass as it enters a more confined pathway.

The ridges which confine the lower section converge near the center of the earthflow where they funnel and constrict movement to a tract roughly 75 meters in width. The ridges act like enormous calipers, pinching off the path through which the earthflow is guided. Several stream-dissected lobe fronts are located at the bedrock constriction. The presence of these lobes in this location suggests the earthflow was unable to pass through the constriction, perhaps indicating its mode of deformation is more rigid-plastic than visco-plastic. As other authors have indicated, visco-plastic materials have a remarkable knack for circumventing obstacles (Iverson 1984, 1986a; Bovis 1986), but Alder earthflow does not appear to be capable of such things. 


\section{Monitoring \& Movement}

Alder earthflow is part of an ongoing investigation by the Forest Service designed to monitor earthflow response to timber harvest. The goal is to identify changes in groundwater levels and earthflow movement and relate these to planned tree thinning and the resultant effects of reduced evapotranspiration and root strength. Pre-harvest and postharvest data are to be acquired. An 30 meter inclinometer and three piezometers were installed during January of 1992 . One piezometer, with its tip set at a depth of 8 meters, was installed on stable ground and used as the control site for groundwater conditions. The inclinometer and remaining piezometers were installed on what appeared to be marginally stable ground, located just below a secondary scarp. The piezometers are nested in one drill hole, their tips set at depths of 6 and 13.5 meters. In addition, six Williamson drive probes were installed to acquire shallow groundwater and soil density information.

During the installation of the inclinometer, a geologic contact was identified at a depth of approximately 6.5 meters, which coincided with the depth of a perched water table. The material change at the contact was from loose silty sand to well-cemented volcaniclastic rock. Blow counts for the standard penetration test jumped from 13 to 50 which was considered refusal. Seismic readings seemed to support this contact, though it is not clear if the water table was instead detected. Inclinometer readings taken over the last 18 months show surface displacement of less than 1 centimeter, indicating that the geologic contact is probably not an active slide plane. However, since this amount of shifting can occur as the inclinometer tube settles, the readings might not reflect actual movement patterns. Nonetheless, the overall movement profile resembles that typically associated with creep. 


\section{HAPPY CREEK EARTHFLOW DEPOSIT}

\section{Morphology}

The Happy Creek earthflow deposit adjoins the Collowash River approximately one kilometer south of the Dickey Creek tributary (Figure 29). Surrounded on three sides by volcaniclastic formations, the long, narrow deposit is the central feature in the Happy Creek watershed. At roughly 250 hectares, it one of the larger earthflow landforms found in the study area. Its surface gradient is about 12 degrees in the lower two thirds, departing locally by as much as 20 degrees. The upper third consists of two scarps, sloping 35 to 40 degrees, that form two large steps. Between these scarps is a broad, flat area, known as Bob Meadow, that contains the largest of many sag ponds located throughout the deposit. Happy Creek, the main drainage, has a high discharge even in summer, and in places is incised to a depth of 15 meters.

Throughout the watershed, there is abundant evidence of past and recent slope movements. Quaternary landsliding is indicated by the large headwall scarp in the interfluve of the watershed, secondary scarps, several perennial sag ponds, and the overall form of the watershed. Comparatively recent slumping has occurred along the toe slope in colluvial hollows between shallow resistent ridges. The slump blocks are well vegetated, regularly spaced, and create an obvious stair-step pattern when seen in profile. Debris slides, the most active type of slope movement in the watershed, are found within the deeply-incised channel of Happy Creek, particularly in cut-bank locations, and on slopes exceeding about 30 degrees. There is also evidence of past debris flow activity associated with dam-break floods (Benda and Zhang 1989; Johnson 1990). These occur in narrow reaches of channels during peak stream flow events when large organic debris or, more commonly, other debris flow deposits temporarily impound water (Coho and Burges 


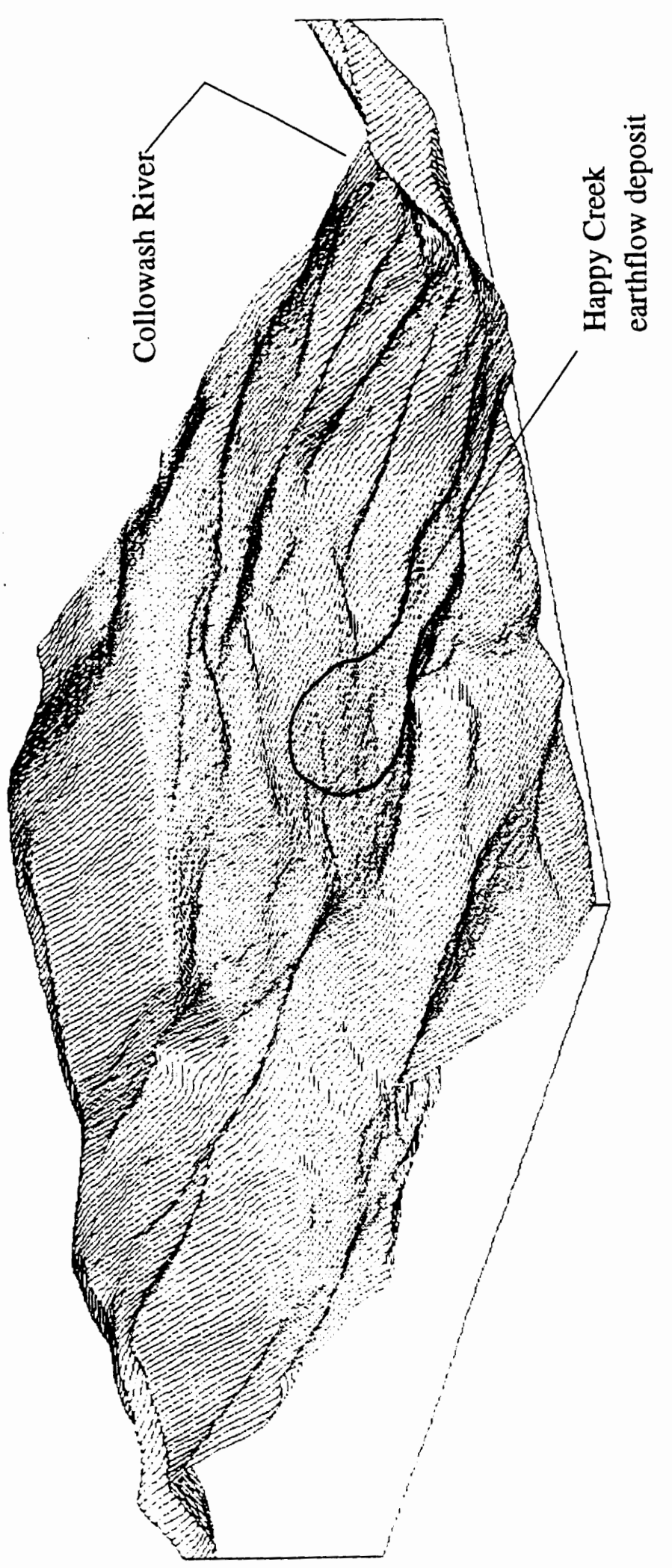

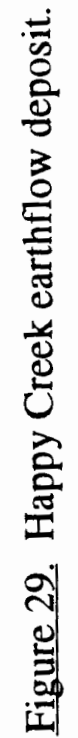


1991). Peak discharge of floods caused by dam failure greatly exceeds the discharge associated with normal flooding, as does the damage. Although the earthflow itself is currently stable, there is evidence of recurrent movements in the past. The channel of Happy Creek has been displaced at least two times, leaving well-developed but abandoned or under-fit stream channels in the lower third of the deposit. These channels are probably the result of brief accelerations at the toe.

\section{Monitoring \& Movement}

Like Alder, the Happy Creek earthflow deposit is part of a multi-year study designed to evaluate the effects of timber harvest on earthflow terrain. The research, which is part of a cooperative effort between the Forest Service and the Intermountain Research Station, is in its initial stages, and instrumentation has not yet been installed. Consequently, data on pre-harvest movement rates, soil moisture, and piezometric levels have not been collected. Some field reconnaissance and stability modeling have been completed, however, and preliminary results indicate the deposit is either stable or moving imperceptibly.

\section{NON-EARTHFLOW LANDFORMS}

\section{$\underline{\text { Basalt }}$}

Three samples were collected from a Tertiary basaltic intrusion near the Happy Creek watershed, whose surface has been exposed throughout the Holocene, and possibly longer. The soil is thin, coarse-grained, shows weakly developed horizons, and may be colluvial. This arrangement, shallow bedrock overlain by regolith, is more conducive to debris sliding than earthflow, particularly when slopes exceed about 25 degrees (Sidle et al. 1985). 


\section{Glacial Till}

Five samples were collected from unsorted deposits of glacial till: two from younger till, deposited 20,000 to $12,500 \mathrm{BP}$, and the remaining three from older till, deposited roughly 100,000 BP (Hammond et al. 1982). The younger deposit shows almost no soil development and contains a large percentage of oversized, sub-rounded clasts. The older deposit is finer-grained and shows more soil development; its color is reddish brown (5YR 5/6) and horizons are distinct. Neither deposit appears to have been influenced by slopemovements.

\section{Alluvial Terrace Deposits}

The final three samples were collected from an alluvial terrace of the Clackamas River, whose elevation is approximately 7 meters above river level. Although the age of the terrace is unknown, it is currently home to many large conifers, putting its minimum age at several hundred years. Where it was sampled, the surface of the terrace is somewhat irregular, and it is possible that small debris flows have periodically deposited material, though very few oversized rocks were visible. 


\section{CHAPTER VI}

\section{RESULTS \& DISCUSSION}

Ninety-six soil samples were collected during March and April of 1993, and several sites were resampled in December of 1993. Of the 96 samples, 49 were from active earthflows and 36 from earthflow deposits. The remaining 11 sample sites were located on stable landforms that have not been influenced by earthflow activity. In all calculations, particles $2 \mu \mathrm{m}$ in size or smaller were assumed to be clay. The entire data set is presented in Appendix A, and the mean soil properties for each landform in Appendix B.

\section{MAJOR INFLUENCES ON EARTHFLOW ACTIVITY}

Earthflow activity is controlled by soil strength, angle of the failure surface or shear zone, toe erosion, and boundary roughness conditions (Bovis 1985; Iverson 1986a; Zhang 1991a). Included in the strength parameter are the influences of particle size, clay type, moisture content, and pore-water pressure (Mitchell 1976).

\section{Strength Characteristics}

Clay content is the most important soil property investigated in this study because of its influence on shear strength and, thus, stability. Generally speaking, an increase in the clay content of a particular soil will cause cohesion to increase and friction angle to decrease (Collotta et al. 1989; Moore 1991). In terms of shear strength, these changes may offset one another if pore-water pressure remains constant. However, since moisture-holding capacity also increases with clay content, pore-water pressure is apt to rise, resulting in an overall decrease in shear strength. Similarly, an increase in clay content causes a soil to 
behave plastically over a wider range of moisture contents, which means the soil is more often in a potentially unstable state. The point is that a clay-rich soil depends on cohesion for its strength because frictional resistance is negligible.

As clay content increases, frictional resistance makes less of a contribution to shear strength. At clay contents above 35 to 50 percent, the behavior of the soil is determined by the clay fraction (Skempton 1953). The particle size distribution of the Collowash earthflow suggests it has sufficient amounts of clay to minimize frictional resistance, yet insufficient amounts to obtain much strength from cohesion, particularly along existing failure surfaces.

As a clay-rich soil fails, several things may happen to perpetuate unstable conditions (Wu and Sangrey 1978). Two of these were mentioned above and are intimately related: increased moisture-holding capacity due to remolding and a concomitant increase in porewater pressure. A third is the reorientation of clay particles parallel to the failure surface, which is often evidenced by slickensides. These physical changes in soil properties cause shear strength along the failure plane to diminish to some residual value, primarily as a result of reduced cohesion. In fact, under failed conditions, in soils with clay contents in excess of 50 percent, the residual strength at the failure plane does not depend on cohesion, but "depends almost entirely on sliding friction of the clay particles" (Skempton 1985). Therefore, not only is a clay-rich soil that fails likely to continue failing, but it is likely to do so along the same surface.

\section{Slope Angle}

Earthflow gradients in the study area range from about 5 to 20 degrees, with the majority occurring between 10 and 15 degrees. Steeper slopes tend to produce shallow debris slides, while discrete failures of any kind are unlikely in slopes below about 5 degrees (Sidle et al. 1985). A slope having the appropriate angle, however, is not certain 
to result in an earthflow; suitable soil properties and hydrologic conditions, each in excess of their respective threshold, are larger prerequisites. Thus, for a soil with a particular set of hydrologic and material conditions, there exists a unique slope angle below which failure will not occur, and above which will result in failure or acceleration. If conditions of the soil change in such a way to decrease its stability, an increase in pore pressure, for instance, then the slope angle required for failure will be less.

There is some disagreement in findings over the role slope angle plays in the behavior of earthflows. Swanston (1981) reports that slope angle "exerted no detectable control over variations in movement rate or process." Instead, he concluded that water content and material properties had a greater impact on earthflow behavior. In contrast, Iverson (1984) and Zhang (1991a) have found that even minor topographic changes have a profound influence on not only movement rates, but also on the style of internal deformation. My observations of active earthflows suggest that only when suitable soil properties and hydrologic conditions are in place does slope angle affect an earthflow's behavior. For example, although Junction earthflow consists of lower strength material than the Collowash, its rate of movement is less because, in part, its slope angle is less. Similarly, even though the slope angles of Alder and Happy Creek earthflow deposits are higher than those of active earthflows, because their soils have higher shear strengths, they are currently inactive.

\section{Toe Erosion}

The toe of an earthflow that adjoins a river is often over-steepened, saturated, and bare; consequently, it is often the site of intense geomorphic activity. Actual transfer of debris into a river channel occurs in three main ways: subaerial surface erosion, masswasting, and entrainment of sediment along the wetted surface. The specific process which dominates depends largely on soil, vegetation, and hydrologic conditions, but also on 
movement rates of the earthflow, river stage, and the tendency of the river to cut laterally. Such a potential for flux implies frequent readjustments are required to maintain equilibrium and result in a variety of slope forms depending on local conditions.

It is sometimes difficult to tell if the river is simply removing the material of an advancing earthflow, or if the river is actually destabilizing the earthflow by eroding and undercutting the toe. Nonetheless, undercutting of an earthflow toe by river erosion is analogous to the removal of any landslide deposit, and can cause the earthflow to accelerate (Kelsey 1978; Iverson 1984). Both the Collowash earthflow and the Alder earthflow deposit adjoin rivers which are actively eroding their toes. Collowash earthflow, however, is rapidly advancing and isolated failures in the toe sometimes constrict the river channel. Since these typically occur during the wet season when the river stage is high, the deposits are quickly carried away. In contrast, the Alder earthflow deposit is not advancing, and the erosion that occurs is limited to undercutting in cut-bank positions of the river channel, which often result in debris slides along the toe.

\section{Landform shape}

The topography surrounding an earthflow can directly affect its activity by impeding movement. Topographic obstacles such as shallow bedrock or intrusives may block or redirect earthflow movement, causing it to slow or stop depending on its rheology. The internal movement of pore water, however, moves relatively unchanged through the slide mass, causing pore water pressure to diminish and shear strength to increase. Alternatively, less viscous earthflows may undergo flow bifurcation when they encounter an obstacle (Bovis 1985, 1986). This behavior is observed where the Collowash earthflow encounters a shallow bedrock knob and one arm of earthflow material diverges from the main body, but rejoins it once again a short distance below the knob. Because the diverted material continues to deform, pore water pressure is maintained and movement persists. 
Furthermore, since its cross-sectional area is reduced, the material may actually accelerate as it moves around the bedrock knob.

Landform shape may also affect earthflow movement by altering local groundwater conditions in terms of the amount of water available and the duration of its availability. An area to which groundwater is persistently directed becomes one of increased pore water pressure and weathering rates. Although sustained pore water pressure is needed to maintain earthflow movement, momentary increases in pore pressure may accelerate movement. Furthermore, movement that is triggered by brief increases in pore pressure may continue when pore pressure dissipates.

While the shape of a landform controls the direction of groundwater movement, the area and elevation of land serving as a catchment determines the amount of water available and the timing of its delivery. For example, the catchment area of Collowash earthflow is larger and higher than that of Junction, thus providing copious snowmelt into late spring. Junction, however, appears to receive water year-round from a large perennial sag pond located upslope. In contrast, Alder earthflow deposit is located on the point of a ridge, and water tends to be directed away from the deposit. The shape of the Happy Creek watershed, despite its size and elevation, does little to alter groundwater conditions of the earthflow deposit because its soils are coarse and well-drained.

\section{SOIL PROPERTIES}

One of the subordinate goals of this study was to date individual earthflow advances using soil development, a technique that has been used with ample success on welldrained, stable landforms (Harden 1982, 1990). The method relies on the fact that when the factors of soil formation (Jenny 1941) are identical, development occurs as a function of time. Unfortunately, this technique could not be used because it requires that soils be 
well-drained, which is not the case. In addition, soils found on landforms of known dates, such as glacial moraines, are not forming in the same parent material as soils found on earthflow terrain. Without this corresponding baseline reference, absolute dating is not possible. Although some relative differences in soil development between earthflows were apparent, they were not enough on their own to make conclusive statements about earthflow age.

\section{Field Moisture}

Water content is a crucial factor when considering the strength of a soil. As the water content of a soil mass approaches saturation, void spaces filled previously by air become filled by water, and the additional weight loads the soil and reduces the volume of the voids. Since water is not easily compressed, a reduction in the volume of a saturated soil raises the pore water pressure which in turn reduces the effective stress and lowers shear strength. Similar reductions in shear strength occur when expansive clays swell with the adsorption of water. Organic content is also a factor since it increases a soil's moisture holding capacity without adding to shear strength (Borchardt 1977).

Moisture content depends on the availability of water, but also on the amount of clay a soil contains. In general, earthflow activity is assumed to increase with higher water contents. The mean field moisture content for the active earthflows (56\%; s.d. 12.0$)$ is higher than that of earthflow deposits (46\%; s.d. 7.9) and non-earthflow landforms (36\%; s.d. 4.0) (Table I). Moisture contents as high as 90 percent by dried weight were recorded for soils from Junction earthflow (Appendix A). Curiously, the mean field moisture contents of Collowash earthflow and Alder earthflow deposit are nearly identical, even though the soils of Alder are more permeable and have deeper groundwater levels. It is possible that Alder contains more organic matter or that the samples misrepresent natural conditions. Due to their coarser particle sizes, soils from the Happy Creek earthflow 
TABLE I

MEAN VALUES FOR SOIL SAMPLES FROM ALL LANDFORM TYPES

\begin{tabular}{|c|c|c|c|c|c|c|c|c|c|c|}
\hline & \multicolumn{3}{|c|}{ Active Earthflows } & \multicolumn{3}{|c|}{ Earthflow Deposits } & \multicolumn{4}{|c|}{ Non-Earthflow Landforms } \\
\hline & ₹总 & 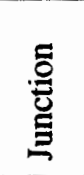 & $\begin{array}{l}\text { 胥 } \\
\text { 害 } \\
\overline{0}\end{array}$ & そ营 & $\frac{\mathrm{g}}{4}$ & $\begin{array}{l}\text { 商总 } \\
\text { 至 }\end{array}$ & 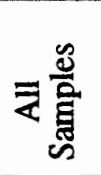 & $\begin{array}{l}\text { 总 } \\
\text { 总 } \\
\text { 尊 }\end{array}$ & $\underset{\tilde{J}}{\stackrel{\pi}{0}}$ & 葾 \\
\hline Observations (N) & 49 & 25 & 24 & 36 & 28 & 8 & 11 & 3 & 5 & 3 \\
\hline Liquid Limit & $78 \%$ & $87 \%$ & $69 \%$ & $60 \%$ & $62 \%$ & $47 \%$ & N/A & NP & NP & $46 \%$ \\
\hline Plastic Limit & $37 \%$ & $40 \%$ & $34 \%$ & $47 \%$ & $48 \%$ & $39 \%$ & N/A & NP & NP & $33 \%$ \\
\hline Plasticity Index & $41 \%$ & $47 \%$ & $35 \%$ & $13 \%$ & $14 \%$ & $8 \%$ & N/A & NP & NP & $13 \%$ \\
\hline Liquidity Index & 0.49 & 0.53 & 0.45 & -0.14 & -0.17 & 0.01 & N/A & NP & $\mathrm{NP}$ & 0.37 \\
\hline Activity & 1.01 & 0.94 & 1.08 & 0.61 & 0.62 & 0.57 & N/A & NP & $\mathrm{NP}$ & 1.08 \\
\hline Field Moisture & $56 \%$ & $62 \%$ & $50 \%$ & $46 \%$ & $49 \%$ & $38 \%$ & $36 \%$ & $36 \%$ & $35 \%$ & $39 \%$ \\
\hline Clay Content & $46 \%$ & $52 \%$ & $35 \%$ & $24 \%$ & $28 \%$ & $10 \%$ & $5 \%$ & $6 \%$ & $3 \%$ & $9 \%$ \\
\hline Silt Content & $32 \%$ & $30 \%$ & $37 \%$ & $30 \%$ & $31 \%$ & $29 \%$ & $23 \%$ & $19 \%$ & $17 \%$ & $36 \%$ \\
\hline Sand Content & $20 \%$ & $17 \%$ & $24 \%$ & $40 \%$ & $35 \%$ & $55 \%$ & $50 \%$ & $58 \%$ & $48 \%$ & $45 \%$ \\
\hline Gravel Content & $2 \%$ & $1 \%$ & $4 \%$ & $6 \%$ & $6 \%$ & $6 \%$ & $22 \%$ & $17 \%$ & $32 \%$ & $10 \%$ \\
\hline Depth (cm) & 81 & 80 & 81 & 84 & 89 & 68 & 73 & 63 & 75 & 79 \\
\hline Dry Unit Wt. $(\mathrm{g} / \mathrm{cc})$ & 1.44 & 1.47 & 1.42 & 1.70 & 1.68 & 1.75 & 1.78 & 1.83 & 1.77 & 1.70 \\
\hline Friction Angle & $15^{\circ}$ & $13^{\circ}$ & $17^{\circ}$ & $24^{\circ}$ & $22^{\circ}$ & $30^{\circ}$ & $31^{\circ}$ & $32^{\circ}$ & $34^{\circ}$ & $26^{\circ}$ \\
\hline Shear Strength $(\mathrm{kPa})$ & 13 & 15 & 11 & 43 & 39 & 51 & 61 & 60 & 70 & 53 \\
\hline Slope Angle & $12^{\circ}$ & $10^{\circ}$ & $14^{\circ}$ & $14^{\circ}$ & $16^{\circ}$ & $12^{\circ}$ & N/A & $20^{\circ}$ & $5^{\circ}$ & $0^{\circ}$ \\
\hline
\end{tabular}


deposit and the non-earthflow landforms had lower mean field moisture contents, ranging from 35 to 39 percent (Table I).

\section{Atterberg Limits}

Atterberg limits are measures of soil consistency that indicate how a soil will behave at a given water content (Yong and Warkentin 1975). Soils for which Atterberg limits can be determined are said to exhibit plasticity. Under a steady stress, plastic soils deform continuously without rupturing and do not regain their original form when the stress is removed (Grim 1962). Deformation occurs by inter-particle sliding and is facilitated by the adsorption of water films. The stress required to initiate movement must exceed the tension of the water films (Baver et al. 1972), and the inter-particle bonds must be sufficiently weak to break under stress, but sufficiently strong to reform when the stress is removed (Yong and Warkentin 1975).

Many factors affect the Atterberg limits of a given soil: the type and amount of dominant clay mineral, the type of exchangeable cation, particle fineness, drying, organic content, and level of disaggregation during sample preparation (Grim 1962). Although increases in clay content cause both the liquid and plastic limits to increase (White 1949; Skempton 1953), the liquid limit increases more, causing the plasticity index to increase as well (Seed et al. 1964a, 1964b).

The results of this study indicate that soils associated with active earthflows behave more plastically than soils associated with earthflow deposits and non-earthflow landforms. The mean liquid limit for active earthflows is 78 percent (s.d. 15.7) and the mean plastic limit is 37 percent (s.d, 5.6), yielding a plasticity index of 41 percent (s.d. 14.1) (Table I). In contrast, soils from earthflow deposits have lower liquid limits and higher plastic limits, 60 percent (s.d. 10.5) and 47 percent (s.d. 7.9) respectively, resulting in a plasticity index 
of only 13 percent (s.d. 7.4). Except for terrace deposits, which have a mean liquid limit of 46 percent (s.d. 2.7) and a mean plasticity index of 13 percent (s.d. 2.7), all samples from non-earthflow landforms were non-plastic.

The soils of Junction earthflow are by far the most plastic of those examined. Their mean liquid limit and plasticity index are 87 percent (s.d. 15.4) and 47 percent (s.d. 15.8), respectively (Table I). The highest liquid limit and plasticity index recorded, 118 percent and 83 percent, respectively, are from Junction (Appendix A). Such high plasticity values for naturally occurring soils may indicate a significant expansive clay content, but because the range of plasticity for different clay minerals tends to overlap (Mitchell 1976), it is difficult to tell which clay mineral is dominant. In comparison, the mean liquid limit and plasticity index of the Collowash earthflow are 69 percent (s.d. 9.3) and 35 percent (s.d. 7.9), respectively (Table I). Although Collowash soils are less plastic, its rate of movement is roughly two orders of magnitude greater than that of Junction, suggesting that movement is not a function of plasticity alone and that plasticity is not always indicative of movement.

At 62 percent (s.d. 8.7), the liquid limit of Alder earthflow is almost as high as that of the Collowash earthflow, but its smaller plasticity index means it behaves plastically over a smaller range of moisture contents than the Collowash (Table I). This difference in plasticity is caused primarily by clay type, but may also reflect slight differences in amount. All but one sample from Alder exhibited plasticity; the non-plastic sample, taken near a tributary of the Oak Grove Fork, was rich in sand and contained only a small amount of clay (Appendix A). Similarly, the soils of Happy Creek earthflow deposit exhibit little plasticity because of their high sand content (Table I). Although only two of the eight samples from Happy Creek are non-plastic, their mean plasticity index is only 8 percent (s.d. 8.9), indicating that these soils are very close to being non-plastic. 
As mentioned above, soils from terrace deposits were the only samples from nonearthflow landforms that showed any plasticity. Soils forming in colluvial basalt and glacial till contained small amounts of silt and clay ( $\leq 25$ percent) and large amounts of sand. In contrast, terrace deposits had a mean silt and clay content of 45 percent (Table I). Although terrace deposits also had high sand contents ( 45 percent), much of the sand fraction was coarser than a number 40 sieve $(0.425 \mathrm{~mm})$ and was therefore excluded from the Atterberg tests.

The liquidity index is related to the Atterberg Limits in that it is used to express field moisture in terms of the plasticity index (Cooper 1979). Its value indicates the state of a soil as it exists with a particular water content: negative values mean the soil is below the plastic limit (solid or semi-solid state); values greater than 1 mean the soil is above the liquid limit (liquid state); and values between 0 and 1 mean the soil is between the plastic and liquid limits (plastic state). For a given soil, an increase in water content generally causes the liquidity index to rise, reflecting the soil's tendency to behave more like a liquid. The mean liquidity index of active earthflows, while not particularly high $(0.49 ;$ s.d. 0.3$)$, was nevertheless several times higher than the mean liquidity index of earthflow deposits $(-0.14 ;$ s.d. 1.0$)$, indicating that field moisture contents at the time of sampling were closer to the liquid limit for active earthflows than for earthflow deposits. Although observations of soil moisture were made only once during the year, they were made in March and April, close to the time of greatest soil moisture. Therefore, it appears that soils comprising active earthflows are above the plastic limit for longer time periods and are more frequently above the liquid limit than earthflow deposits.

Although the plasticity index tends to increase linearly with clay content, it does so at different rates depending on which clay types are dominant. The slope of the line that represents this relationship is termed the activity and reflects the swelling potential of the soil (Skempton 1953). The mean activity of clays in the active earthflows $(A=1.01$; s.d. 
$0.4)$ is significantly higher than that of earthflow deposits $(A=0.61$; s.d. 0.3$)$ (Figure 30), and falls within the range of values Skempton classified as "normal clays" (Table I). However, fully 20 percent of the samples from Junction and Collowash earthflows have activities above 1.25, putting them in the category of "active clays" (Skempton 1953). In contrast, the mean activity of earthflow deposits falls within the range of values classified as "inactive clays." This difference suggests active earthflows have a higher percentage of expandable clays such as smectite, than earthflow deposits, which probably contain more kaolinite or halloysite. The mean activity value for terrace deposits is 1.08 , but this figure may be misleading. When clay contents are low, even a small plasticity index will lead to high activity values. For example, if clay content is 4 percent, a plasticity index of 11 percent means the activity is 2.75 . Also, when the number of observations is small, as it is here, true conditions may be misrepresented and a single spurious value, such as the one in the example above, will skew the activity toward an unrealistically high value.

\section{Particle Sizes}

Active earthflows are composed of finer particles than earthflow deposits and nonearthflow landforms, which tend to contain more sand and gravel (Figure 31). The mean clay content of Junction earthflow is 52 percent (s.d. 12.6) and that of Collowash earthflow is 35 percent (s.d. 10.7). In comparison, Alder contains about 28 percent clay (s.d. 15.9) , Happy Creek only 10 percent (s.d. 10.1), and non-earthflow landforms about 5 percent (s.d. 3.2) (Table I). The clay content of active earthflows and earthflow deposits is largely a function of the high clay-bearing potential of the parent material and the amount of weathering the parent material has undergone. Since both of these vary with local conditions, clay distribution is not uniform. Furthermore, it is commonly found that clay content increases with soil depth in a well-developed soil profile. This relationship appears to exist for earthflow deposits because they have been stable long enough for clay 


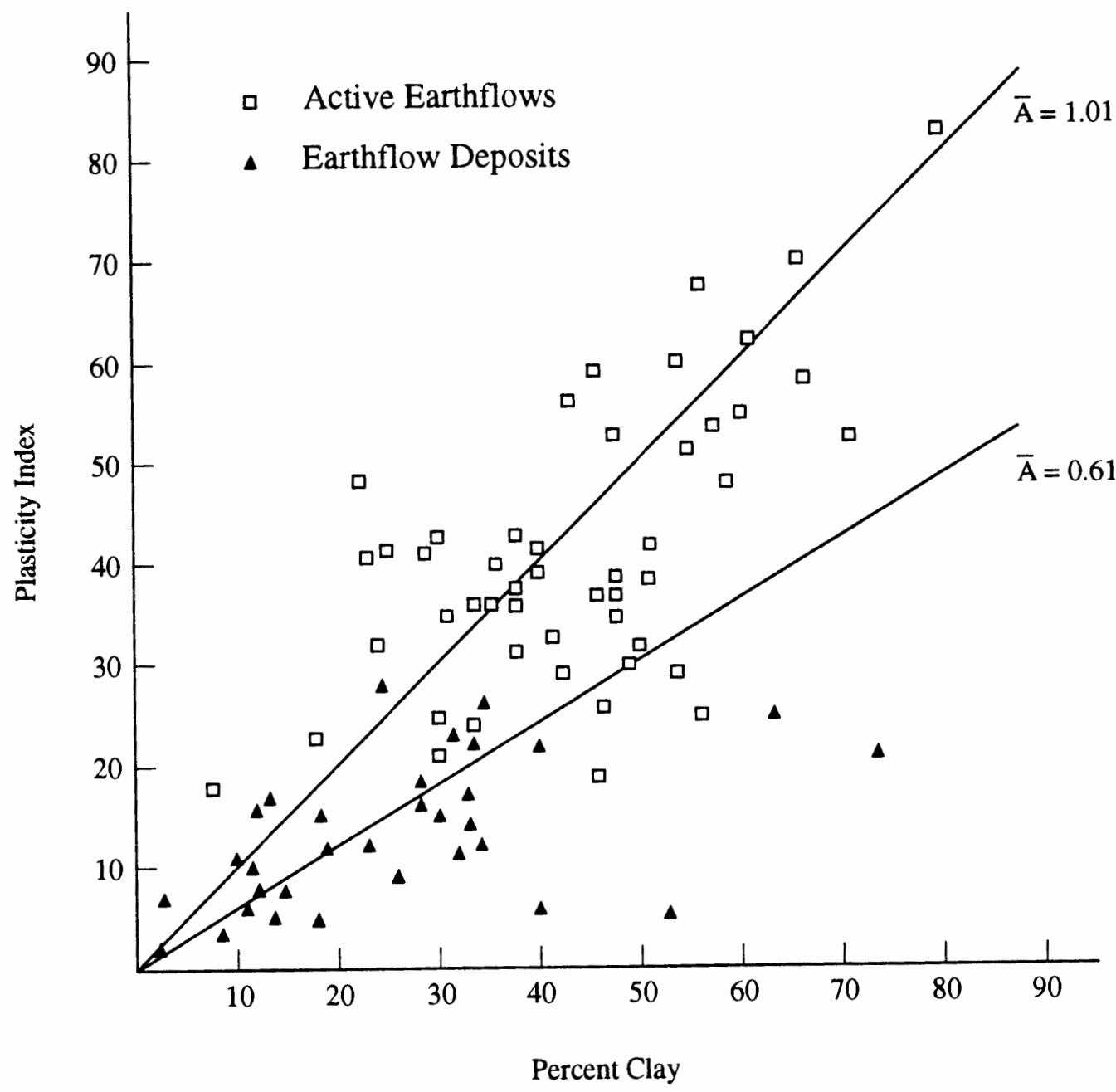

Figure 30. Activity chart. Relationship between plasticity index and percent clay for active earthflows and earthflow deposits. Note: The line representing the activity of soils with clay contents greater than $40 \%$ normally passes through the origin, but for soils with smaller amounts of clay, the line passes through the $\mathrm{x}$-axis between 0 and $10 \%$ (Seed et al. 1964b). 


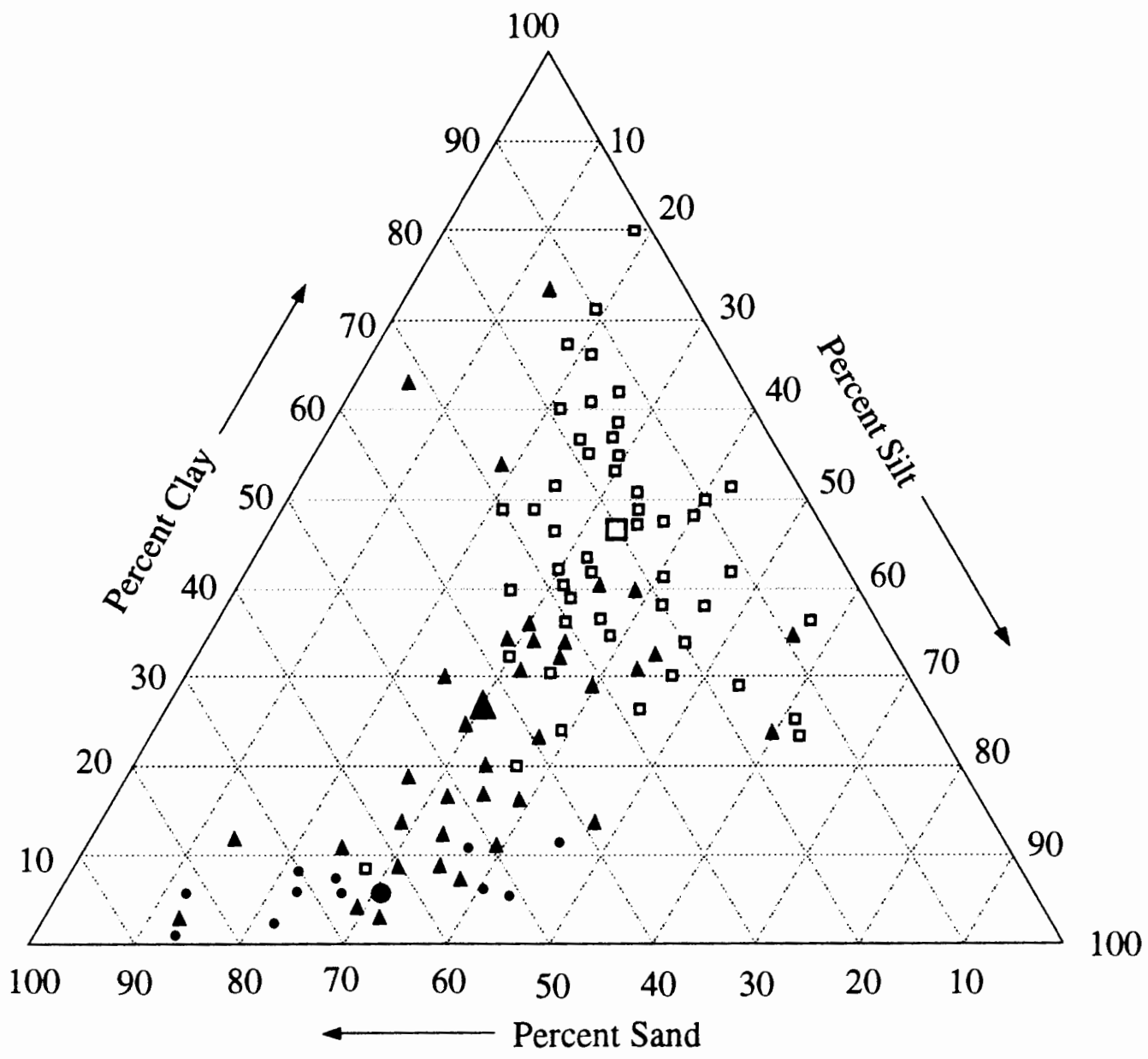

- Active earthflow \ Earthflow deposit - Non-earthflow landform

Figure 31. Soil Particle Sizes. Percentages of sand, silt, and clay for samples from active earthflows, earthflow deposits, and non-earthflow landforms. Large symbols denote mean values. Note that mean silt contents are very similar for each landform type, approximately 30 percent. 
translocation to occur, but not for active earthflows because adverse leaching conditions and continual disturbance preclude clay translocation. Similarly, this relationship does not exist for non-earthflow landforms because their parent material is less clay-bearing and slow to weather.

Although clay types were not identified in this study, the high plasticity index of active earthflows suggests a dominance of expandable clay minerals such as smectite. Indeed, Gradusov (1974) indicates that smectite is common in western Oregon, and Keith (1988) shows that the entire study area falls within a zone of zeolite-clay mineral assemblages where smectite is predominant. Moreover, Borchardt (1977) and Mutchler (1987) have found that smectite content and plasticity correspond directly if smectite is present. With this relationship in mind, the linear function established by Mutchler was used to estimate smectite contents of the soil samples in this study. The results indicate that active earthflows contain substantially more smectite than earthflow deposits and nonearthflow landforms. These results are in agreement with those of Paeth and others (1971), who used x-ray diffraction to determine smectite contents of soils in the Western Cascades, and Bovis (1985) who examined earthflows in British Columbia. However, other authors working in the Pacific Northwest have found that hydrated halloysite and amorphous materials, not smectite, are the dominant clay minerals in earthflows (Pope and Anderson 1960; Taskey 1977; Taskey et al. 1978; Istok and Harward 1982). Since the plasticity range of these clay minerals overlaps with that of smectite, it is not possible to tell which mineral combination exists without mineralogical analysis.

Silt contents are remarkably similar for earthflow landforms, ranging between 29 and 37 percent, and averaging 32 percent (s.d. 10.7) for active earthflows and 30 percent (s.d. 11.2) for earthflow deposits (Table I). The mean silt content of terrace deposits also falls in this range (36\%; s.d. 5.7), but mean silt contents for basalt and till parent material are 
less than 20 percent. The silt fraction, in sharp contrast to clay, does not appear to affect earthflow behavior. This is indicated by the weak correlations it has with all the soil properties considered, and by the fact that silt contents are essentially identical for active earthflows and earthflow deposits (Table I; Figure 31).

Sand and gravel are the opposing counterparts to clay, and contribute to shear strength by simultaneously increasing friction angle and permeability. The mean sand content of the active earthflows is low (20\%; s.d. 10.2) compared to that of earthflow deposits (40\%; s.d. 16.9) and non-earthflow landforms (50\%; s.d. 6.8) (Table I). The mean gravel content of earthflow landforms is very low (4\%; s.d. 3.6), but fairly high for non-earthflow landforms (22\%; s.d. 11.8). These differences are largely controlled by geology.

Under the Unified Soils Classification (Casagrande 1948), soils from active earthflows are classified as inorganic silts and clays of high plasticity and, within these groupings, range from sandy elastic silt to fat clay. Earthflow deposits consist mostly of inorganic silts of high and low plasticity, and range from silty sand to elastic silt. Soils of non-earthflow landforms range from low plasticity sandy silt to non-plastic silty sand with gravel. In comparison, under the USDA classification (Soil Survey Staff 1951), soils from active earthflows are predominantly clays with some silty clays, clay loams, and silty clay loams. Earthflow deposits tend to be loams, clay loams, and sandy loams, while nonearthflow landforms consist of sandy loams and and loamy sands.

The plasticity chart shows that soils from active earthflows plot roughly parallel to the A-line, which is a characteristic of soils having similar geologic origins (Figure 32). In contrast, the plotting of soils from earthflow deposits is somewhat scattered, suggesting they consist of a wider range of parent materials. The result is a soil whose particle size distribution is better graded than that of active earthflows. A larger assortment of particle 


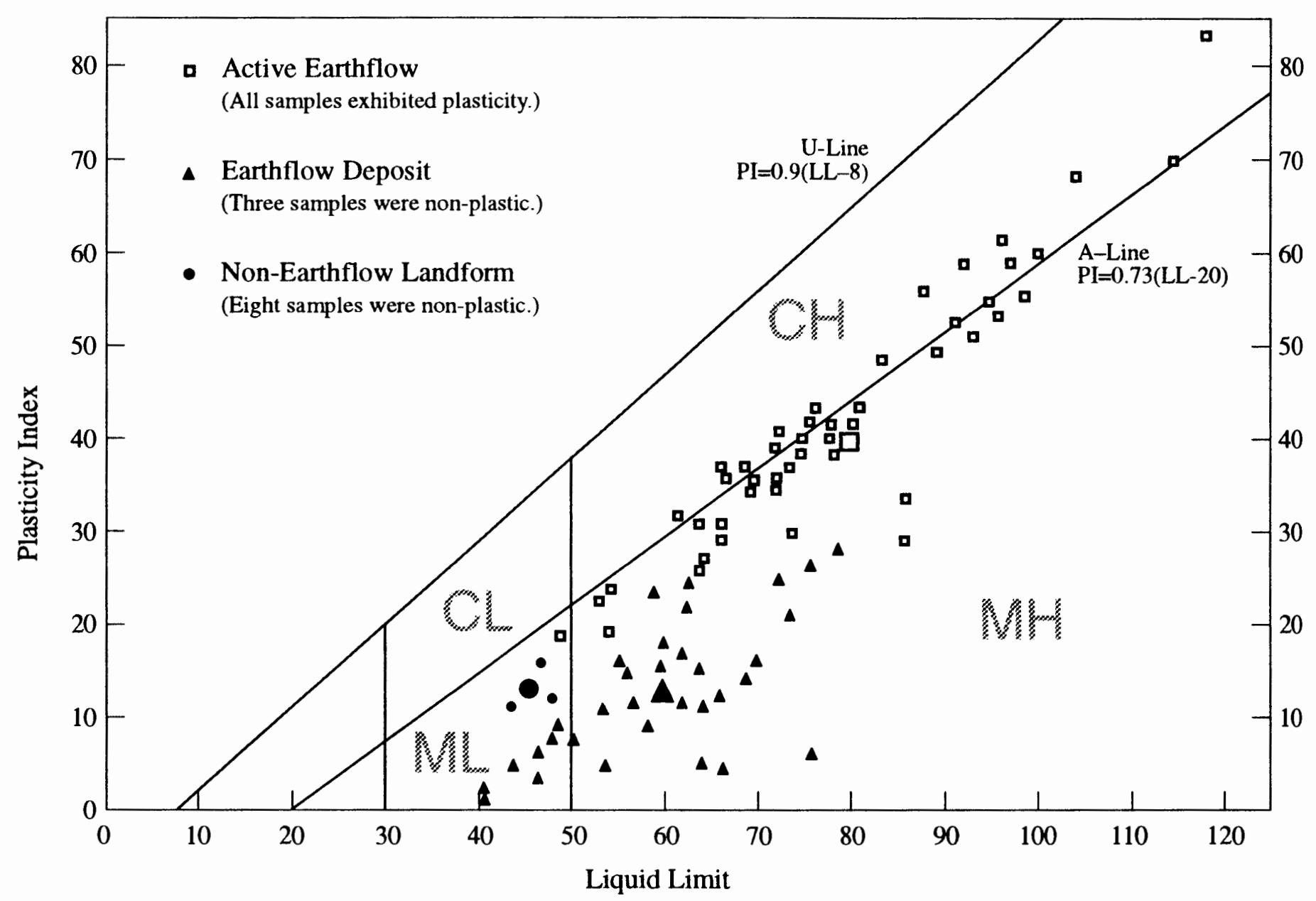

Figure 32. Plasticity Chart. Each sample exhibiting plasticity is denoted by a small symbol. Eleven samples are non-plastic and could not be plotted. All non-earthflow samples shown represent terrace deposits. Large symbols denote mean values. 
sizes allows more inter-granular contact and causes the friction angle to increase, resulting in a more stable soil.

\section{Strength Characteristics}

Shear strength is largely a function of soil properties such as grain size and moisture content, and is generally represented by the Mohr-Coulomb failure criteria (Das 1990):

$$
\tau=\mathrm{c}+\sigma_{f} \tan \phi
$$

where $\tau=$ shear strength; $c=$ cohesion; $\sigma_{f}=$ normal stress acting on the failure plane; and $\phi=$ friction angle.

Dry unit weight tends to decrease with clay content and increase with sand or gravel content. The mean dry unit weight of active earthflows, at $1.44 \mathrm{~g} / \mathrm{cc}$, is substantially lower than that of earthflow deposits and non-earthflow landforms: 1.70 and $1.77 \mathrm{~g} / \mathrm{cc}$ respectively (Table I). Similarly, friction angle and shear strength tend to decrease with clay content. For example, with almost 50 percent of their weight in clay, the mean friction angle of active earthflows is 15 degrees, while mean shear strength is $13 \mathrm{kPa}$. Upon drying, the shear strength of these soils would increase. Conversely, with only 5 percent of their weight in clay, the mean friction angle of non-earthflow landforms is 31 degrees and mean shear strength is $61 \mathrm{kPa}$. Earthflow deposits, whose mean clay content is 24 percent, have a mean friction angle of 24 degrees and a mean shear strength of $43 \mathrm{kPa}$. These soils are less affected by drying because they are comparatively well-drained, and their strength depends on frictional resistance, rather than cohesion. 


\section{CORRELATIONS}

\section{Atterberg Limits}

A summary of the relationships between soil properties and site characteristics is presented in Table II. Since these variables reflect or depend on the texture and moisture of the soil, it comes as no surprise that many correlations are high and 52 of 85 are significant at the 5 or 1 percent level. Seven of the variables correlate highly with eight or more of the others, while only two variables correlate with fewer than five (Table II). Often, a high correlation between two variables is caused not by their innate relationship, but by the fact that both are functions of a third variable.

As Appendix C indicates, however, the relationships are somewhat different when a single landform (e.g., Junction earthflow) or group of landforms (e.g., active earthflows) is considered, as opposed to all samples at once. For example, the correlation coefficient between the liquid limit and plasticity index for active earthflows is 0.94 at the 0.1 confidence level, but when all samples are considered, the same correlation is only 0.31 (Appendix C). This may be caused by the fact that, as a group, active earthflows are relatively homogeneous in terms of soil properties. Sampling size may also influence the outcome.

The liquid limit is correlated at the 0.1 percent confidence level with, among others, the plasticity index, moisture, and clay content, but it is poorly correlated with the liquidity index, depth, and surprisingly, the plastic limit (Table II). The plastic limit shows only weak correlations with most of the variables, while the plasticity index is one of the most highly correlated variables investigated, showing correlations with 11 of 13 variables at the 1 percent confidence level. Direct relationships between the plasticity index and clay content have been observed elsewhere (Skempton 1953; Borchardt 1977), and this relationship appears to hold in this study where the correlation coefficient for the 85 
TABLE II

\section{CORRELATION MATRIX OF SOIL PROPERTIES AND SITE CHARACTERISTICS FOR ALL SAMPLES}

$\begin{array}{lccccccccccccccc}\text { LL } & \text { PL } & \text { PI } & \text { LI } & \text { A } & \text { M } & \text { Cl } & \text { Slt } & \text { Snd } & \text { Gv } & \text { D } & \gamma_{\mathrm{d}} & \phi_{\mathrm{r}}{ }^{\prime} & \tau & \\ \text { LL } & 1.0 & - & - & - & - & - & - & - & - & - & - & - & - & - \\ \text { PL } & .08 & 1.0 & - & - & - & - & - & - & - & - & - & - & - & - \\ \text { PI } & .90^{*} & -.36^{*} & 1.0 & - & - & - & - & - & - & - & - & - & - & - \\ \text { LI } & .10 & -.50^{*} & .31^{*} & 1.0 & - & - & - & - & - & - & - & - & - & - \\ \text { Activity } & .28 & -.45^{*} & .46^{*} & .14 & 1.0 & - & - & - & - & - & - & - & - & - \\ \text { Moisture } & .56^{*} & .14 & .47^{*} & .44^{*} & -.04 & 1.0 & - & - & - & - & - & - & - & - \\ \text { Clay } & .77^{*} & .01 & .72^{*} & .19 & -.17 & .67^{*} & 1.0 & - & - & - & - & - & - & - \\ \text { Silt } & -.07 & -.15 & -.01 & .21 & .26^{\dagger} & .18 & -.04 & 1.0 & - & - & - & - & - & - \\ \text { Sand } & -.65^{*} & .09 & -.65^{*} & -.31^{*} & .05 & -.62^{*} & -.82 & -.42 & 1.0 & - & - & - & - & - \\ \text { Gravel } & -.47^{*} & -.03 & -.43^{*} & -.10 & -.09 & -.54^{*} & -.59 & -.39 & .44 & 1.0 & - & - & - & - \\ \text { Depth } & .11 & .20 & .02 & -.09 & -.18 & .09 & .24^{\dagger} & .08 & -.26^{*} & -.14 & 1.0 & - & - & - \\ \gamma_{\mathrm{d}} & -.46^{*} & .63^{*} & -.73^{*} & -.55^{*} & -.46^{*} & -.54^{*} & -.70^{*} & -.49 & .72^{*} & .61^{*} & -.03 & 1.0 & -- & - \\ \phi_{\mathrm{r}}{ }^{\prime} & -.86^{*} & .17 & -.88^{*} & -.33^{*} & -.22^{\dagger} & -.68^{*} & -.89^{*} & -.25^{\dagger} & .85^{*} & .68^{*} & -.20 & .83^{*} & 1.0 & - \\ \tau & -.40^{*} & .56^{*} & -.62^{*} & -.42^{*} & -.26 & -.47^{*} & -.62^{*} & -.34^{\dagger} & .63^{*} & .58^{*} & -.10 & .83^{*} & .77^{*} & 1.0\end{array}$

*Significant at the 1 percent confidence level. ${ }^{\dagger}$ Significant at the 5 percent confidence level. Note: Dry unit weight, residual friction angle and shear strength are denoted by $\gamma_{d}, \phi_{\mathrm{T}}^{\prime}$, and $\tau$, respectively. Relationships between textural classes are not statistically significant because they represent percentages of a constant whole. 
samples that exhibited plasticity is 0.72 (Table II). The liquidity index and activity, which are partly a function of plasticity, are poorly correlated with many of the variables, with the plastic limit and plasticity index being the most notable exceptions.

\section{Field Moisture}

Field moisture content correlates strongly with clay and sand and the variables that depend on clay and sand, such as the liquid limit $(r=0.56)$ and friction angle $(r=-0.68)$ (Table II). In contrast, moisture appears to be unrelated to activity $(r=-0.04)$ and depth $(r$ $=0.09$ ), which are two of the more independent variables in the study. Moisture and shear strength show a moderate negative correlation $(r=-.61)$ for the cohesive soils of active earthflows, but are poorly correlated $(r=0.25)$ for earthflow deposits which do not depend on cohesion for their shear strength, but rather on frictional resistance, which is less affected by changes in moisture. Moreover, the clay fraction of earthflow deposits appears to be more kaolinitic, which is less reactive with water than expansive clays such as smectite.

\section{$\underline{\text { Particle Sizes }}$}

Classes of particle sizes are expected to show a high degree of negative correlation with each other since they represent percentages of a constant whole. When the percentage of one class decreases, the percentage of another increases. This relationship is most clear in the sand and clay pairing where $r=-0.82$, and least clear in the pairing of sand and gravel which shows a positive correlation of 0.44 . This suggests the break between sand and gravel is rather artificial since they appear to act as one class.

With the exception of silt, which is one of the more independent of the variables considered, particle size classes correlate highly with many other variables. Typically, where clay shows a strong positive correlation, sand shows a strong negative correlation. 
A perfect example is the liquid limit, with which both correlate at the 0.1 percent level: for clay, $\mathrm{r}=0.77$; for sand, $\mathrm{r}=-0.65$ (Table II). Similarly, clay and sand appear to have equal and opposite influences on moisture content, bulk density, and shear strength.

The correlations between depth and the other variables are low (Table II), possibly because the range of depths considered ( 0.5 to 1.4 meters) was too small for any effects to appear. Had samples been taken through the entire soil profile to depths of a few meters, relationships between depth, moisture, bulk density, and shear strength might have become evident. Clay content is one variable that might be expected to show some correlation with depth, yet generally speaking, it is uniformly distributed with depth. This is probably a function of disturbance, young soils, and the clay-bearing qualities of the parent material, all of which tend to negate the effects of pedogenic processes which may influence clay distribution on older, more stable surfaces.

The remaining variables, dry unit weight, friction angle, and shear strength, depend largely on soil texture, and therefore show a high degree of correlation with most of the variables except activity, silt content, and depth. Since friction angle was determined solely on the basis of its inverse relationship with clay content and plasticity, its correlation coefficients are somewhat less meaningful than those of dry unit weight and shear strength, which were measured in situ. Nevertheless, the strong positive correlation between shear strength and friction angle $(r=0.77)$ implies that the inferred friction angles are fairly accurate (Table II). 


\section{CHAPTER VII}

\section{CONCLUSIONS}

Earthflows are an important and prevalent form of mass-wasting in the upper Clackamas River watershed where they mobilize out of Quaternary landslide deposits and consist chiefly of clay-bearing volcaniclastic material such as weathered tuffs, breccias, and laharic deposits. Their morphology, which reflects movement rates, is typical of earthflows found throughout the Western Cascades, and commonly includes scarps, lobes, tension cracks, shear zones, sag ponds, and tilted trees. Some morphological evidence suggests these earthflows are long-lasting features that have been intermittently active during the Holocene and perhaps longer. Moreover, the presence of stabilized earthflow deposits suggests that much of the regional earthflow activity was initiated under different climatic conditions.

My research suggests the fundamental difference between active earthflows, earthflow deposits, and non-earthflow landforms is clay content. Active earthflows tend to be rich in clay (46\%; s.d. 14.5$)$ and poor in sand (20\%; s.d. 10.2). Consequently, they have large liquid limits (78\%; s.d. 15.7) and plasticity indices (41\%; s.d. 14.1) and field moisture contents (56\%; s.d. 12.0) that are well above the plastic limit throughout much of the year, even when precipitation is scarce. In contrast, earthflow deposits have smaller liquid limits (60\%; s.d. 10.5), small plasticity indices (13\%; s.d. 7.4), and lower field moisture contents ( $46 \%$; s.d. 7.9 ) because they contain more sand ( $40 \%$; s.d. 16.9$)$ and less clay (24\%; s.d. 16.4). Similarly, non-earthflow landforms rarely exhibit plasticity 
because they contain miniscule amounts of clay (5\%; s.d. 3.2) but are rich in sand (50\%; s.d. 6.8) and gravel (22\%; s.d. 11.8).

A key difference between active earthflows and earthflow deposits appears to be in the types of dominant clays, which were inferred from the activity of the clay fraction and the plasticity index. Active earthflows contain a larger percentage of expansive clays than earthflow deposits, which contain more stable clays such as kaolinite or halloysite. Several authors working in the Pacific Northwest have identified smectite as the dominant type of clay associated with earthflows, and the activity (1.01) and plasticity index (41\%) values I observed support this. Taskey (1977), however, observed that hydrated halloysite and amorphous gels frequently comprise a large percentage of the clay fraction of earthflows, and that the earthflow mass may be sliding on a thin layer of smectite. Although this is plausible, Forest Service drill hole data from Junction earthflow indicate that the plasticity index is nearly constant throughout the thickness of the earthflow, suggesting that clay types and proportions are uniform with depth. Below the basal margin, however, there is an abrupt decrease in plasticity, perhaps as a result of different types of clay.

Although clay content and clay type are critical, other complementary factors are needed to produce an earthflow. When the necessary soil properties are in place, the influence of slope angle, hydrologic conditions, and toe erosion become increasingly important. For example, the clay and moisture contents of the Collowash earthflow suggest it is more stable than Junction earthflow, yet it moves much faster because its toe is constantly being eroded. On the other hand, if the toe of Junction begins to be eroded, it will accelerate. Other conditions, such as topographic obstacles and boundary roughness, may also influence movement rates and patterns. For example, the flow bifurcation witnessed on the Collowash earthflow results in two distinct arms of earthflow movement which appear to move at different rates. 
The critical pieces of information for evaluating actual or potential earthflow activity are soil strength, moisture, slope angle, toe erosion, and boundary roughness conditions. With the exception of toe erosion, it is best to acquire these values from the failure plane or the shear zone of the earthflow, since this is where movement occurs. The drawback in using near-surface soil properties to evaluate earthflow activity is that they may not accurately represent the soil properties found along an existing or potential failure surface. For instance, a stable, shallow soil may be underlain by a thin zone of low-strength material that may destabilize with small increases in shear stress. However, my results show that, with this exception, near-surface soil properties are somewhat reflective of stability, even though a soil of low strength does not inevitably cause higher rates of earthflow movement. Therefore, with care, shallow soil properties may be taken into consideration when delineating areas of questionable stability.

\section{FUTURE WORK}

Many new questions concerning earthflows have arisen over the past two decades as a result of detailed and lengthy investigations. Although attempts to answer some of these questions are currently underway, several have received less attention than they warrant. Three main areas need further work: (1) understanding the role of earthflows in forested ecosystems; (2) the ability to predict earthflow behavior; and (3) the long-term contribution of earthflows to the evolution of landscapes. Any advances in these areas will result in better forest management.

Many earthflows are affected by planned resource activities such as logging and road construction. Because the behavior of an earthflow is complex and depends on local conditions, accurately predicting its response to these activities is extremely difficult, and may require a detailed investigation of the earthflow. Several studies have explored a particular earthflow and have supplied valuable information with which its behavior can be 
reasonably approximated. However, investigating earthflows in such detail is not only costly but impractical for the shear magnitude of the project. An alternative that would be of value to land managers is an inexpensive tool or model that could be used to quickly evaluate the potential risk of a change in earthflow behavior in response to forest practices. By using site characteristics and index properties of soils, earthflow landforms could be ranked in terms of their suitability for an intended land use. For example, an earthflow landform that consists predominantly of silt and sand and contains little water might tolerate a particular land use better than one having greater amounts of clay (Figure 33).

There are several questions to be answered in order for the role of earthflows in forested ecosystems to be better understood. The most timely of these concerns the response of active and inactive earthflows to timber harvesting. Many multi-year studies have begun and some have already resulted in important discoveries about earthflow behavior. The next step is to establish management guidelines for earthflow terrain that can be applied regionally and are based on quantitative determination of earthflow behavior as it is influenced by land management activities.

Within the Mt. Hood National Forest, there are many opportunities to advance our understanding of earthflows, and some of these have region-wide implications. There is an urgent need for improved mapping of of earthflow landforms. The current mapping strategy in the Mt. Hood Forest Plan does not draw distinctions between active and inactive earthflows (USFS 1990a). Rather, all earthflow landforms, as well as other ancient landslide deposits, are distinguished according to risk of monetary loss based on their proximity to infrastructure and natural features of some assumed value (e.g., fish-bearing streams). Many landforms that fall into the high risk category are known to be stable but continue to be managed as a high risk site. 


\begin{tabular}{|c|c|c|c|c|}
\hline & & & Toe erosion & No toe erosion \\
\hline \multirow{4}{*}{$\begin{array}{l}\text { High clay } \\
\text { content } \\
>50 \%\end{array}$} & \multirow{2}{*}{$\begin{array}{c}\text { High water } \\
\text { content }\end{array}$} & Gradient $>15^{\circ}$ & 8 & 7 \\
\hline & & Gradient $<10^{\circ}$ & 7 & 6 \\
\hline & \multirow{2}{*}{$\begin{array}{c}\text { Low water } \\
\text { content }\end{array}$} & Gradient $>15^{\circ}$ & 6 & 5 \\
\hline & & Gradient $<10^{\circ}$ & 5 & 4 \\
\hline \multirow{4}{*}{$\begin{array}{c}\text { Low clay } \\
\text { content } \\
<35 \%\end{array}$} & \multirow{2}{*}{$\begin{array}{c}\text { High water } \\
\text { content }\end{array}$} & Gradient $>15^{\circ}$ & 4 & 3 \\
\hline & & Gradient $<10^{\circ}$ & 3 & 2 \\
\hline & \multirow{2}{*}{$\begin{array}{c}\text { Low water } \\
\text { content }\end{array}$} & Gradient $>15^{\circ}$ & 2 & 1 \\
\hline & & Gradient $<10^{\circ}$ & 1 & 0 \\
\hline
\end{tabular}

Figure 33. Earthflow Risk to Management. One possible strategy for ranking earthflows in terms of their potential for movement. Higher numbers represent greater sensitivity to forest practices. 
There is also a need to determine unequivocally the predominant clay types found in earthflows of the Cascade Mountains. Although the literature indicates that both hydrated halloysite and smectite are common in earthflows, the issue of clay type is not directly addressed. It is important to know if both clay types occur because this may help explain morphological or behavioral differences in earthflows.

Sediment production is one of the driving factors behind the interest in earthflows; yet within the Mt. Hood National Forest, no quantitative information about sediment production from earthflows has been gathered. By monitoring sediment production from earthflows, several important questions can be answered: What is the sediment contribution of earthflows compared to that of other managed landforms? What controls the rate of sediment delivery? What are the particle sizes introduced by earthflows and how long does sediment from earthflows stay in suspension? There are many more and, although the task is not easy, they must be answered if we are to manage earthflows prudently and understand their importance as a geomorphic process. 


\section{REFERENCES CITED}

Amaranthus, M.P., Rice, R.M., Barr, N.R., Ziemer, R.R., 1985: Logging and Forest Roads related to increased Debris Slides in Southwestern Oregon, Journal of Forestry, vol. 83, no. 4, p. 229-233.

American Association of State Highway and Transportation Officials, 1986: Standard Specifications for Transportation Materials and Methods of Sampling and Testing, Part II: Methods of Sampling and Testing, 14th edition, American Association of State Highway and Transportation Officials, Washington D.C., 1275 p.

American Society for Testing and Materials, 1986: ASTM Book of Standards, vol. 04.08, Philadelphia, PA.

Anderson, J.L., 1978: The Stratigraphy and Structure of the Columbia River Basalt in the Clackamas River Drainage: Portland, Oregon, Portland State University, M.S. Thesis, $136 \mathrm{p}$.

Barnes, F.F., Butler, J.W., 1930: The Structure and Stratigraphy of the Columbia River Gorge and Cascade Mountains in the Vicinity of Mt. Hood, Unpublished Master's Thesis, University of Oregon, Eugene, Oregon, 136 p.

Baver, L.D., Gardner, W.H., Gardner, W.R., 1972: Soil Physics, Wiley, New York, 4th edition.

Benda, L.E., Zhang, W., 1989: The Hydrological and Geomorphological Characteristics of Landslide/Dam-Break Floods in the Cascade Range of Washington, EOS: Transactions of the American Geophysical Union 1124.

Benda, L.E., 1990: The Influence of Debris Flows on Channels and Valley Floors in the Oregon Coast Range, Earth Surface Processes and Landforms, vol. 15, no. 5, p. 457-466.

Bjerrum, L., 1954: Stability of Natural Slopes in Quick Clay, Géotechnique, vol. 5, p. 101-119.

Bjerrum, L., Løken, T., Heiberg, S., Foster, R., 1971: A Field Study of Factors Responsible for Quick Clay Slides, Norwegian Geotechnical Institute, Publication No. 85 , p. 17-26. 
Blackwelder, E., 1912: The Gros-Ventre Slide: An Active Earth-Flow, Geological Society of America Bulletin, vol. 23, p. 487-492.

Blackwelder, E., 1928: Mudflow as a Geologic Agent in Semi-Arid Mountains, Geological Society of America Bulletin, vol. 39, p. 465-483.

Borchardt, G.A., 1977: Clay Mineralogy and Slope Stability, California Division of Mines and Geology, Special Report 133, 15 p.

Bovis, M.J., 1985: Earthflows in the Interior Plateau, Southwest British Columbia, Canadian Geotechnical Journal, vol. 22, p. 313-334.

Bovis, M.J., 1986: The Morphology and Mechanics of large-scale Slope Movement, with particular reference to Southwest British Columbia, in Hillslope Processes, A.D. Abrahams (ed.), Allen and Unwin, Winchester, MA, p. 319-341.

Bowles, D.S., ed., 1985: Delineation of Landslide, Flash Flood, and Debris Flow Hazards in Utah, Proceedings of a Specialty Conference, Utah State University, Utah Water Research Laboratory, Logan, Utah.

Brabb, E.E., 1989: Landslides: Extent and Economic Significance in the United States, in Landslides: Extent and Significance, E.E. Brabb and B.L. Harrod, eds., 385 p.

Bromhead, E.N., 1992: The Stability of Slopes, 2nd. ed., Blackie Academic \& Professional, Glasgow, NZ, 411 p.

Cabrera, J.G., Smalley, I.J., 1973: Quickclays as products of Glacial Action: A new approach to their Nature, Geology, Distribution, and Geotechnical Properties, Engineering Geology, vol. 7, p. 115-133 and 361-363.

Carson, M.A., 1976: Mass Wasting, Slope Development, and Climate, in E. Derbyshire, ed., Geomorphology and Climate, p. 101-136.

Carson, M.A., Lajoie, G., 1981: Some Constraints on the Severity of Landslide Penetration in Sensitive Deposits, Geog. Phys. et Quat. vol. 35, p. 301-316.

Casagrande, A., 1948: Classification and Identification of Soils, American Society of Civil Engineers, vol. 113, p. 901-930.

Chandler, R.J., 1986: Processes leading to Landslides in Clay Slopes: a review, in Hillslope Processes, A.D. Abrahams (ed.), Allen and Unwin, Winchester, MA, p. 343-360. 
Chatwin, S.C., Howes, D.E., Schwab, J.W., Swanston, D.N., 1991: A Guide for Management of Landslide-Prone Terrain in the Pacific Northwest, British Columbia Ministry of Forests, Victoria, B.C., 212 p.

Coffin, B.A., Harr, R.D., 1992: Effects of Forest Cover on Volume of Water Delivery to Soil during Rain-on-Snow, unpublished USDA Forest Service final report for Project SH-1, originally Project 18, 118 p.

Coho, C., Burges, S.J., 1991: Analysis of Initiation Mechanisms of Dam-Break Floods in Managed Forests, Department of Civil Engineering, University of Washington, Seattle, Water Resources Technical Report, TFW-SH9-91-001, 23 p.

Collotta, T., Cantoni, R., Pavesi, U., Ruberi, E., Moretti, P.C., 1989: A Correlation Between Residual Friction Angle, Gradation, and the Index Properties of Cohesive Soils, Géotechnique, vol. 39, no. 2, p. 343-346.

Cooper, R., 1979: Relationships between Plasticity, Natural Moisture Conditions, and Surface Stability of some Slope Soils near Helmsley, North Yorkshire, in Geographical Approaches to Fluvial Processes, Pitty, A.F., ed., Geo Abstracts, Ltd., Norwich, England, 300 p.

Costa, J.E., 1984: Physical Geomorphology of Debris Flows, in Developments and Applications of Geomorphology, Costa, J.E., Fleisher, P.J., eds., Springer-Verlag, Berlin, p. 268-317.

Crawford, C.B., 1968: Quick Clays of Eastern Canada, Engineering Geology, vol. 2, no. 4 , p. 239-265.

Cumulative Effects Steering Committee, 1992: Watershed Analysis Manual: Cooperative Monitoring Evaluation and Research Steering Committee of the Timber, Fish, \& Wildlife Agreement, Washington State, TFW-CEI-92-002.

Cunningham, M.J., 1972: A Mathematical Model of the Physical Processes of an Earthflow, New Zealand Journal of Hydrology, vol. 11, no. 1, p. 47-54.

Das, B.M., 1990: Principles of Geotechnical Engineering, PWS-Kent Publishing Company, Boston, MA, $665 \mathrm{p}$.

DeRoo, T., 1993: Forest Geologist, Mt. Hood National Forest, personal communication.

Dyhrman, R.F., 1975: Geology of Bagby Hot Springs Area, Clackamas and Marion Counties, Oregon, unpublished Master's Thesis, Oregon State University, Corvalis, Oregon, $78 \mathrm{p}$. 
Dyrness, C.T., 1967: Mass Soil Movements in the H.J. Andrews Experimental Forest, USDA Forest Service Research Paper PNW-42, 12 p.

Evans, S.G., 1982: Landslides and Surficial Deposits in Urban Areas of British Columbia: A Review, Canadian Geotechnical Journal, vol. 19, p. 269-288.

FEMAT, 1993: Forest Ecosystem Management: An Ecological, Economic, and Social Assessment, Report of the Forest Ecosystem Management Assessment Team.

FEMAT, 1994: A Federal Agency Guide for Watershed Analysis, v. 1.2, 189 p.

Franklin, J.F., Dymess, C.T., 1973: Natural Vegetation of Oregon and Washington, Oregon State University Press, 452 p.

Gradusov, B.P., 1974: A Tentative Study of Clay Mineral Distribution in Soils of the World, Geoderma, vol. 12, p. 49-55.

Gray, D.H., 1970: Effects of Forest Clearcutting on the Stability of Natural Slopes, Association of Engineering Geologists Bulletin, vol. 7, nos. 1 \& 2, p. 45-67.

Greenway, D.R., 1987: Vegetation and Slope Stability, in, Slope Stability-Geotechnical Engineering and Geomorphology, Anderson, M.G., Richards, K.S., (eds.), Wiley \& Sons, $648 \mathrm{p}$.

Gresswell, S., Heller, D., Swanston, D.N., 1979: Mass-Movement Response to Forest Management in the Central Oregon Coast Ranges, USDA Forest Service, Pacific Northwest Forest and Range Experiment Station, Resource Bulletin PNW-84, 26 p.

Grim, R.E., 1962: Applied Clay Mineralogy, McGraw-Hill, New York, 422 p.

Halverson, N.M., Topik, C., Van Vickle, R., 1986: Plant Association and Management Guide for the Western Hemlock Zone: Mt. Hood National Forest, USDA Forest Service Report, RC-ECOL-232A-1986, 111 p.

Hammond, P.E., Geyer, K.M., Anderson, J.L., 1982: Preliminary Geologic Map and Cross Sections of the Upper Clackamas and North Santiam Rivers Area, Northern Oregon Cascade Range, Portland State University Department of Earth Sciences, Portland, OR, scale: $1: 62,500$.

Harden, J.W., 1982: A Quantitative Index of Soil Development from Field Descriptions: Examples from a Chronosequence in Central California, Geoderma, vol. 28, p. 1-28. 
Harden, J.W 1990: Soil Development on Stable Landforms and Implications for Landscape Studies, Geomorphology, vol. 3, p. 391-398.

Harr, R.D., 1986: Effects of Clearcutting on Rain-on-Snow Runoff in Western Oregon: A new Look at Old Studies, Water Resources Research, vol. 22, no. 7, p. 1095-1100.

Hays, W.W., 1981: Facing Geologic and Hydrologic Hazards, Earth-Science Considerations, United States Geological Survey Professional Paper 1240-B, U.S. Government Printing Office, Washington D.C., 109 p.

Howe, E., 1909: Landslides in the San Juan Mountains, Colorado, U.S. Geological Survey Professional Paper 67, 58 p.

Hutchinson, J.N., 1961: A Landslide on a Thin Layer of Quick Clay at Furre, Central Norway, Géotechnique, vol. 11, p. 69-94.

Innes, J.L., 1983: Debris Flows, Progress in Physical Geography, vol. 7, p. 469-501.

Istok, J.D., Harward, M.E., 1982: Clay Mineralogy in Relation to Landscape Instability in the Coast Range of Oregon, Soil Science Society of America Journal, vol. 46, p. $1326-1331$.

Iverson, R.M., 1984: Unsteady, Non-Uniform Landslide Motion: Theory and Measurement, Ph.D. Thesis, Stanford University, Stanford, California, 303 p.

Iverson, R.M., 1985: A Constitutive Equation for Mass-Movement Behavior, Journal of Geology, vol. 93, p. 143-160.

Iverson, R.M., 1986a: Dynamics of Slow Landslides: A Theory for Time-Dependent Behavior, in Hillslope Processes, A.D. Abrahams (ed.), Allen and Unwin, Winchester, MA, p. 297-317.

Iverson, R.M., 1986b: Unsteady, Nonuniform Landslide Motion: 1. Theoretical Dynamics and the Steady Datum State, Journal of Geology, vol. 94, p. 1-15.

Iverson, R.M., 1986c: Unsteady, Nonuniform Landslide Motion: 2. Linearized Theory and the Kinematics of Transient Response, Journal of Geology, vol. 94, p. 349-364.

Iverson, R.M., Denlinger, R.P., 1987: The Physics of Debris Flows-A Conceptual Assessment, in Erosion and Sedimentation in the Pacific Rim, Beschta, R.L., Blinn, T., Grant, G.E., Ice, G.G., Swanson, F.J., eds., Proceedings of the Corvalis Symposium, IAHS Publication no. 165, $510 \mathrm{p}$. 
Iverson, R.M., Major, J.J., 1987: Rainfall, Ground-Water Flow, and Seasonal Movement at Minor Creek Landslide, Northwestern California: Physical Interpretation of Empirical Relations, Geological Society of America Bulletin, vol. 99, p. 579-594.

Jenny, H., 1941: Factors of Soil Formation, McGraw-Hill, New York, 186 p.

Johnson, A.C., 1990: The Effects of Landslide Dam-Break Floods on the Morphology of Channels, Unpublished Master's Thesis, College of Forest Resources, University of Washington, TFW-SH17-91-001, 90 p.

Johnson, A.M., 1965: A Model for Debris Flow, unpublished Ph.D. dissertation, Pennsylvania State University, University Park, PA.

Johnson, A.M., 1970: Physical Processes in Geology, Freeman, Cooper, \& Co., 577 p.

Johnson, A.M., with contributions from Rodine, J.R., 1984: Debris Flows, in Slope Stability, Brunsden, ed., Wiley, New York, p. 257-362.

Keefer, D.K., 1976: Earthflows in the Coast Ranges of Central California: Preliminary Report, U.S. Geological Society Open-File Report 76-734, 58 p.

Keefer, D.K., Johnson, A.M., 1978: Mobilization and Movement Mechanics of Earthflows, in Recent Advances in Engineering Science, Sierakowski, R.L., ed., Proceedings: Society of Engineering Science 15th Annual Meeting, Gainesville, Florida, p. 223-225.

Keefer, D.K., Johnson, A.M., 1983: Earth Flows: Morphology, Mobilization, and Movement, USGS Professional Paper 1264, 56 p.

Keith, T.E.C., 1988: Regional Patterns of Hydrothermal Alteration in the BreitenbushAustin Hot Springs area of the Cascade Range, Oregon, in Geology and Geothermal Resources of the Breitenbush-Austin Hot Springs area, Clackamas and Marion Counties, Sherrod, D.R., ed., USGS open-file report 0-88-5, p. 31-37.

Kelsey, H.M., 1978: Earthflows in Franciscan Melange, Van Duzen River Basin, California, Geology, vol. 6, p. 361-364.

Koler, T.E., 1992: Effects of Timber Harvest to Deep-Seated Landslides, unpublished literature search conducted for the Cooperative, Monitoring, Evaluation, and Research Steering Committee, Timber, Fish, \& Wildlife Aggreement TFW-SH5-91-001, 52 p. 
Marden, M., Phillips, C.J., Jackson, R.J., Zhang, X.B., Ekanayake, J., 1992: A Decade of Earthflow Research and Inter-related Studies in the North Island of New Zealand, in Erosion, Debris Flows and Environment in Mountain Regions, Proceedings of the Chengdu Symposium, July, 1992, IAHS Publication no. 209, p. 263-271.

McKean, J., Buechel, S., 1990: Remote Sensing of Forested Earthflows, in Protecting Natural Resources with Remote Sensing, the 3rd Forest Service Remote Sensing Applications Conference, April, 1990, Tucson, Arizona, p. 198-206.

Miles, D.W.R., Swanson, F.J., Youngberg, C.T., 1984: Effects of Landslide Erosion on Subsequent Douglas-Fir Growth and Stocking Levels in the Western Cascades, Oregon, Soil Science Society of America Journal, vol. 48, p. 667-671.

Mitchell, J.K., 1976: Fundamentals of Soil Behavior, Wiley, New York.

Moore, R., 1991: The Chemical and Mineralogical Controls upon the Residual Strength of Pure and Natural Clays, Géotechnique, vol. 41, no. 1, p. 35-47.

Mutchler, J.W., 1987: Causes of Instability on Embankments in Northeast Louisiana, unpublished Master of Science thesis, College of Engineering, Louisiana Tech University, $199 \mathrm{p}$.

National Research Council, 1985: Reducing Losses from Landsliding in the United States, Committee on Ground Failure Hazards, Commission on Engineering and Technical Systems, National Academy Press, Washington, D.C., 41 p.

Neely, M.K., Rice, R.M., 1990: Estimating risk of Debris Slides after Timber Harvest in Northwestern California, Bulletin of the Association of Engineering Geologists, vol. 27, no. 3, p. 281-289.

Nolan, K.M., Janda, R.J., Duls, J.M., 1979: Recent History of the Surface Morphology of two Earthflows adjacent to Redwood Creek, in Guidebook for a Field Trip to observe Natural and Management-related Erosion in Franciscan Terrane of Northern California, Geological Society of America, Cordilleran Section, p. XI1-XI10.

O'Loughlin, C.L., 1974: The Effects of Timber Removal on the Stability of Forest Soils, New Zealand Journal of Hydrology, vol. 13, p. 121-134.

O'Loughlin, C.L., 1981: Tree Roots and Slope Stability, in What's New in Forest Research, Forest Research Institute Publication 104, Rotorua, New Zealand, New Zealand Forest Service. 
Orr, E.L., Orr, W.N., Baldwin, E.M., 1992: Geology of Oregon, 4th ed., Kendall / Hunt Publishing Company, $254 \mathrm{p}$.

Paeth, R.C., Harward, M.E., Knox, E.G., Dyrness, C.T., 1971: Factors Affecting Mass Movement of Four Soils in the Western Cascades of Oregon, Proceedings of the Soil Science Society of America, vol. 35, p. 943-947.

Pearce, A.J., O'Loughlin, C.L., Jackson, R.J., Zhang, X.B., 1987: Reforestation: Onsite Effects on Hydrology and Erosion, Eastern Raukumara Range, New Zealand, Forest Hydrology and Watershed Management, Swanson, R.H., Bernier, P.Y., Woodard, P.D., eds., IAHS pub. 167, 625 p.

Phillips, C.J., Davies, T.R.H., 1991: Determining Rheological Parameters of Debris Flow Material, Geomorphology, Vol. 4, pgs. 101-110.

Phillips, C.J., 1993: Earth Scientist, Landscare Research New Zealand, personal communication.

Pope, R.J., Anderson, M.W., 1960: Strength Properties of Clays Derived from Volcanic Rocks, Research Conference on Shear Strength of Cohesive Soils, ASCE, University of Colorado, Boulder, CO, $1164 \mathrm{p}$.

Pyles, M.R., Mills, K., Saunders, G., 1987: Mechanics and Stability of the Lookout Creek Earth Flow, Bulletin of the Association of Engineering Geologists, vol. 24, no. 2, p. 267-280.

Rawlings, G.E., 1984: Active Slide in Bentonitic Clays, Upper Hat reek, British Columbia, Proceedings of the 4th International Symposium on Landslides, p. 503-510.

Ritter, D.F., 1986: Process Geomorphology, Wm. C. Brown Publishers, Dubuque, Iowa, $579 \mathrm{p}$.

Rosenqvist, 1.Th., 1953: Consideration of the Sensitivity of Norwegian Quick Clays, Géotechnique, vol. 3, p. 195-200.

Rosenqvist, I.Th., 1966: Norwegian Research into the Properties of Quick Clay-a review, Engineering Geology, vol. 1, p. ?.

Rowe, J.S., 1992: The Ecosystem Approach to Forestland Management, The Forestry Chronicle, vol. 68, no. 2.

Savage, W.Z., Chleborad, A.F., 1982: A Model for Creeping Flow in Landslides, Bulletin of the Association of Engineering Geologists, vol., 29, no. 4, p. 333-338. 
Schulz, M.G., 1980: The Quantification of Soil Mass Movements and their Relationships to Bedrock Geology in the Bull Run Watershed, Multnomah and Clackamas Counties, Oregon, M.S. Thesis, Oregon State University, Corvalis, Oregon, 170 p.

Schuster, R.L., 1978: Introduction, chapter 1 in Landslides, Analysis and Control, Schuster, R.L., Krisek, R.J., eds., National Academy of Sciences, Transportation Research Board, Special Report no. 176, p. 1-10.

Schuster, R.L., Fleming, R.W., 1986: Economic Losses and Fatalities due to Landslides, Bulletin of the Association of Engineering Geologists, vol. 23, no. 1, p. 11-28.

Seed, H.B., Woodward, R.J., Lundgren, R., 1964a: Clay Mineralogical Aspects of Atterberg Limits, Journal of the Soil Mechanics \& Foundation Division, Proceedings of the American Society of Civil Engineers, vol. 90 (SM4), p. 107-131.

Seed, H.B., Woodward, R.J., Lundgren, R., 1964b: Fundamental Aspects of the Atterberg Limits, Journal of the Soil Mechanics \& Foundation Division, Proceedings of the American Society of Civil Engineers, vol. 90 (SM6), p. 75-105.

Shannon \& Wilson, Inc., 1975a: Geotechnical Investigation and Studies: Switch Creek Slide, Mt. Hood National Forest, Clackamas County, Oregon, Shannon \& Wilson, Inc., Geotechnical Consultants Portland, OR, 37 p.

Shannon \& Wilson, Inc., 1975b: Geotechnical Investigation: Fish Hatchery Landslide, Mt. Hood National Forest, Clackamas County, Oregon, Shannon \& Wilson, Inc., Geotechnical Consultants, Portland, OR, 27 p.

Sharp, R.P., 1988: Living Ice: Understanding Glaciers and Glaciation, Cambridge University Press, $225 \mathrm{p}$.

Sharpe, C.F.S., 1938: Landslides and Related Phenomena: A Study of Mass Movements of Soil and Rock, Columbia University Press, New York, 137 p.

Sherrod, D.R., Conrey, R.M., 1988: Geologic Setting of the Breitenbush-Austin Hot Springs area, Cascade Range, North-Central Oregon, in Geology and Geothermal Resources of the Breitenbush-Austin Hot Springs area, Clackamas and Marion Counties, Sherrod, D.R., ed., USGS open-file report 0-88-5, p. 1-14.

Sidle, R.C., 1985: Factors Influencing the Stability of Slopes, in Proceedings of a Workshop on Slope Stability: Problems and Solutions in Forest Management, Swanston, D.N., ed., USDA Forest Service, Pacific Northwest Forest and Range Experiment Station, General Technical Report, PNW-180, p. 17-25. 
Sidle, R.C., 1992: A Theoretical Model of the Effects of Timber Harvesting on Slope Stability, Water Resources Research, vol. 28, no. 7, p. 1897-1910.

Sidle, R.C., Pearce, A.J., O'Loughlin, C.L., 1985: Hillslope Stability and Land Use, Am. Geophysical Union, Water Resources Monograph Series 11, 140 p.

Skempton, A.W., 1953: The Colloidal Activity of Clays, Proceedings, 3rd International Conference on Soil Mechanics and Foundation Engineering, London, vol. 1, p. $57-61$.

Skempton, A.W., 1964: Long-Term Stability of Clay Slopes, Géotechnique, vol. 14, no. 2, p. 77-101.

Skempton, A.W., 1985: Residual Strength of Clays in Landslides, Folded Strata, and in the Laboratory, Géotechnique, vol. 35, no. 1, p. 3-18.

Smalley, I.J., Bentley, S.P., Moon, C.F., 1975: The St. Jean Vianney Quickclay, Canadian Mineralogy, vol. 13, p. 247-254.

Smalley, I.J., 1976: Factors relating to the Landslide Process in Canadian Quick Clays, Earth Surface Processes, vol. 1, p. 163-172.

Soil Survey Staff, 1951: Soil Survey Manual, U.S. Department of Agriculture Handbook 18, Soil Conservation Service.

Soil Survey Staff, 1975: Soil Taxonomy, U.S. Department of Agriculture Handbook, Soil Conservation Service.

Swanson, F.J., Benda, L.E., Duncan, S.H., Grant, G.E., Megahan, W.F., Reid, L.M., Ziemer, R.R., 1987: Mass Failures and other Processes of Sediment Production in Pacific Northwest Forest Landscapes, in Streamside Management: Forestry and Fishery Interactions, Salo, E.O., Cundy, T.W., eds., University of Washington, Institute of Forest Resources, p. 9-38.

Swanson, F.J., Dyrness, C.T., 1975: Impact of Clearcutting and Road Construction on Soil Erosion by Landslides in the Western Cascade Range, Oregon, Geology, Vol. 3, p. 393-396.

Swanson, F.J., Franklin, J.F., Sedell, J.R., 1990: Landscape Patterns, Disturbance, and Management in the Pacific Northwest, USA, in Changing Landscapes: An Ecological Perspective, Zonneveld, I.S. and Forman, R.T.T., eds., Springer-Verlag, 286 p. 
Swanson, F.J., Fredriksen, R.L., McCorison, F.M., 1982a: Material Transfer in a Western Oregon Forested Watershed, chapter 8 in Analysis of Coniferous Forest Ecosystems in the Western United States, Edmonds, R.L. (ed.), Hutchinson Ross Publishing Co., 419 p.

Swanson, F.J., Gregory, S.V., Sedell, J.R., Campbell, A.G., 1982b: Land-Water Interactions: The Riparian Zone, chapter 9 in Analysis of Coniferous Forest Ecosystems in the Western United States, Edmonds, R.L. (ed.), Hutchinson Ross Publishing Co., 419 p.

Swanson, F.J., James, M.E., 1975: Geology and Geomorphology of the H.J. Andrews Experimental Forest, western Cascades, Oregon, USDA Forest Service Research Paper, PNW-188, 14 p.

Swanson, F.J., Swanston, D.N., 1977: Complex Mass Movement Terrains in the Western Cascade Range, Oregon, in Reviews in Engineering Geology, vol. 3, Landslides, Coates, D.R., ed., Geological Society of America, p. 69-83.

Swanston, D.N., 1981: Creep and Earthflow Erosion from Undisturbed and Management-Impacted Slopes in the Coast Ranges and Cascade Mountains of the Pacific Northwest, U.S.A., Erosion and Sediment Transport in Pacific Rim Steeplands, International Association of Hydrologists, Scientific Publication 132, p. 76-94.

Swanston, D.N., Lienkaemper, G.W., Merserau, R.C., Levno, A.B., 1988: Effects of Timber Harvesting on Progressive Hillslope Deformation in South-West Oregon, Bulletin of the Association of Engineering Geologists, v. 25, n. 3, p. 371-381.

Swanston, D.N., Swanson, F.J., 1976: Timber Harvesting, Mass Erosion, and Steepland Geomorphology in the Pacific Northwest, in Geomorphology and Engineering, Coates, D.R., ed., Dowden, Hutchinson, \& Ross, Inc., Stroudsburg, PA, p. 199-221.

Taskey, R.D., 1977: Relationship of Clay Mineralogy to Landscape Stability in Western Oregon, Oregon State University, Corvalis, Oregon, Ph.D. Dissertation, 223 p.

Taskey, R.D., Harward, M.E., Youngberg, C.T., 1978: Relationship of Clay Mineralogy to Landscape Stability, in Forest Soils and Land Use, Youngberg, C.T., ed., Proceedings of the 5th N. American Forest Soils Conference, Colorado State University, Ft. Collins, CO, 623 p.

Thomas M.R., Kropp, A.L., 1989: Earthflow Evaluation and Control: A Case History, in Engineering Geology and Geotechnical Engineering, Watters (ed.), A.A. Balkema, Rotterdam, Netherlands, p. 85-92. 
Thomson, S., Mekechuk, J., 1982: A Landslide in Glacial Lake Clays in Central British Columbia, Canadian Geotechnical Journal, vol. 19, p. 296-306.

Torrance, J.K., 1987: Quick Clays, in, Slope Stability-Geotechnical Engineering and Geomorphology, Anderson, M.G., Richards, K.S., (eds.), Wiley \& Sons, 648 p.

U.S. Forest Service, 1979: Soil Resource Inventory, USDA Forest Service, Pacific Northwest Region, Mt. Hood National Forest, 312 p.

U.S. Forest Service, 1981: Earthflow Activation as affected by Timber Harvest Prescriptions, unpublished proposal by the Watershed and Geotechnical Groups, Mt. Hood National Forest, USDA Forest Service, $16 \mathrm{p}$.

U.S. Forest Service, 1990a: Land and Resource Management Plan, Mt. Hood National Forest, USDA Forest Service, Pacific Northwest Region.

U.S. Forest Service, 1990b: Road 46 Reconstruction, Clackamas Ranger District, Mt. Hood National Forest, unpublished USDA Forest Service geotechnical report, 15 p.

Van Asch, Th. W.J., Deimel, M.S., Haak, W.J.C., Simon, J., 1989: The Viscous Creep Component in Shallow Clayey Soil and the Influence of Tree Load on Creep Rates, Earth Surface Processes and Landforms, vol. 14, p. 557-564.

VanDine, D.F., 1980: Engineering Geology and Geotechnical Study of Drynoch Landslide, British Columbia, Geological Survey of Canada Paper 79-31, p. 1-34.

Varnes, D.J., 1958: Landslide Types and Processes, in Landslides and Engineering Practice, Eckel, E.B., ed., Highway Research Board, Washington D.C., p. 20-47.

Varnes, D.J., 1978: Slope Movement Types and Processes, in Landslides: Analysis and Control, Schuster, R.L., Krisek, R.J., eds., National Academy of Sciences, Transportation Research Board, Special Report no. 176, p. 11-33.

Voight, B., 1973: Correlation between Atterberg Plasticity Limits and Residual Shear Strength of Natural Soils, Géotechnique, vol. 28, p. 265-267.

Vulliet, L., Hutter, K., 1988: Viscous-Type Sliding Laws for Landslides, Canadian Geotechnical Journal, vol. 25, p. 467-477.

Walker, J.W., MacLeod, N.S., 1991: Geologic Map of Oregon, U.S. Geological Survey. 
Watson, I., 1984: Hydrogeologic Control and Statistical Prediction of Active Mass Movement, Bulletin of the Association of Engineering Geologists, vol. 21, no. 4, p. 479-494.

White, W.A., 1949: Atterberg Plastic Limits of Clay Minerals, American Mineralogist, vol. 34, p. 508-512.

Whittow, J., 1984: Dictionary of Physical Geography, Penguin Books, New York, New York, $591 \mathrm{p}$.

Wieczorek, G.F., Lips, E.W., Ellen, S.D., 1989: Debris Flows and Hyperconcentrated Floods Along the Wasatch Front, Utah, 1983 and 1984, Bulletin of the Association of Engineering Geologists, vol. 26, no. 2, p. 191-208.

Wilson, S.D., 1970: Observational Data on Ground Movements Related to Slope Stability, Journal of Soil Mechanics and Foundation Division of the American Society of Civil Engineers, vol. 96, p. 1521-1544.

Wolfe, M.D., Williams, J.D., 1986: Rates of Landsliding as Impacted by Timber Management Activities in Northwestern California, Bulletin of the Association of Engineering Geologists, vol. 23, no. 1, p. 53-60.

Wu, T.H., Sangrey, D.A., 1978: Strength Properties and their Measurement, in Landslides: Analysis and Control, Schuster, R.L., Krizek, R.J., eds., National Academy of Sciences, Transportation Research Board, Special Report no. 176, p. 139-154.

Yong, R.N., Warkentin, B.P., 1975: Soil Properties and Behavior, Developments in Geotechnical Engineering Series, Elsevier Scientific Publishing Co., New York, 449 p.

Záruba, Q., Mencl, V., 1969: Landslides and their Control, Elsevier, New York, 205 p.

Zhang, X.B., Phillips, C., Marden, M., 1991a: Internal Deformation of a Fast-Moving Earthflow, Raukumara Peninsula, New Zealand, Geomorphology, vol. 4, p. $145-154$.

Zhang, X.B., Phillips, C., Pearce, A., 1991b: Surface Movement of an Earthflow Complex, Raukumara Peninsula, New Zealand, Geomorphology, vol. 4, p. 261-272.

Zhang, X.B., Phillips, C., Marden, M., 1993: A Comparison of Earthflow Movement Mechanisms on Forested and Grass Slopes, Raukumara Peninsula, North Island, New Zealand, Geomorphology, vol. 6, p. 175-187. 
APPENDIX A

SOIL PROPERTIES FOR EACH SAMPLE 
LEGEND

$$
\begin{aligned}
& \mathrm{LL}=\text { Liquid Limit }(\%) \\
& \mathrm{PL}=\text { Plastic Limit }(\%) \\
& \mathrm{PI}=\text { Plasticity Index }(\%) \\
& \mathrm{LI}=\text { Liquidity Index } \\
& \mathrm{A}=\text { Activity } \\
& \mathrm{M}=\text { Field Moisture Content }(\%) \\
& \mathrm{Cl}=\text { Clay Content }(\%) \\
& \mathrm{Slt}=\text { Silt Content }(\%) \\
& \mathrm{Snd}=\text { Sand Content }(\%) \\
& \mathrm{Gv}=\text { Gravel Content }(\%) \\
& \mathrm{D}=\text { Depth }(\mathrm{cm}) \\
& \gamma_{\mathrm{d}}=\text { Bulk Density }(\mathrm{g} / \mathrm{cc}) \\
& \phi_{\mathrm{r}}^{\prime}=\text { Friction Angle }(\mathrm{degrees}) \\
& \tau=\text { Shear Strength }(\mathrm{kPa})
\end{aligned}
$$


JUNCTION EARTHFLOW SOIL PROPERTIES

$\begin{array}{llllllllllllll}L & \text { PL } & \text { PI } & \text { LI } & \text { A } & \text { M } & \text { Cl } & \text { Slt } & \text { Snd } & \text { Gv } & \text { D } & \gamma_{d} & \phi_{\mathrm{r}}{ }^{\prime} & \tau\end{array}$ $\begin{array}{lllllllllllllll}\text { JEF1 } & 64 & 39 & 25 & .84 & .44 & 60 & 57 & 22 & 18 & 3 & 72 & - & 17 & -\end{array}$ $\begin{array}{lllllllllllllll}\text { JEF2 } & 74 & 44 & 30 & .62 & .61 & 62 & 49 & 20 & 30 & 1 & 79 & - & 16 & -\end{array}$ $\begin{array}{lllllllllllllll}\text { JEF3 } & 104 & 36 & 68 & .25 & 1.2 & 53 & 57 & 28 & 15 & 0 & 65 & - & 10 & -\end{array}$ $\begin{array}{lllllllllllllll}\text { JEF4 } & 96 & 43 & 53 & .32 & 1.1 & 60 & 48 & 24 & 26 & 2 & 72 & - & 13 & 17\end{array}$ $\begin{array}{lllllllllllllll}\text { JEF5 } & 100 & 40 & 60 & .28 & 1.1 & 57 & 54 & 30 & 16 & 0 & 71 & 1.5 & 11 & 15\end{array}$ $\begin{array}{lllllllllllllll}\text { JEF6 } & 115 & 46 & 70 & .45 & 1.1 & 77 & 66 & 22 & 12 & 0 & 79 & 1.5 & 10 & 16\end{array}$ $\begin{array}{lllllllllllllll}\text { JEF7 } & 83 & 35 & 48 & .15 & 2.2 & 48 & 22 & 36 & 36 & 6 & 88 & - & 16 & 21\end{array}$ $\begin{array}{lllllllllllllll}\text { JEF8 } & 79 & 41 & 38 & 1.3 & 1.0 & 90 & 38 & 42 & 20 & 0 & 56 & - & 15 & 7\end{array}$ $\begin{array}{lllllllllllllll}\text { JEF9 } & 95 & 41 & 54 & .28 & .93 & 56 & 58 & 28 & 14 & 0 & 52 & 1.5 & 12 & -\end{array}$ $\begin{array}{lllllllllllllll}\text { JEF10 } & 87 & 54 & 33 & .56 & .80 & 72 & 41 & 40 & 19 & 0 & 75 & 1.5 & 13 & -\end{array}$ $\begin{array}{lllllllllllllll}\text { JEF11 } & 87 & 58 & 29 & .59 & .69 & 75 & 42 & 47 & 11 & 0 & 96 & 1.5 & 17 & -\end{array}$ $\begin{array}{lllllllllllllll}\text { JEF12 } & 93 & 42 & 51 & .35 & .93 & 60 & 55 & 26 & 19 & 0 & 63 & - & 12 & 15\end{array}$ $\begin{array}{lllllllllllllll}\text { JEF13 } & 118 & 35 & 83 & .37 & 1.0 & 66 & 80 & 19 & 1 & 0 & 137 & - & 8 & 16\end{array}$ $\begin{array}{lllllllllllllll}\text { JEF14 } & 67 & 38 & 29 & .86 & .54 & 63 & 54 & 29 & 17 & 0 & 64 & - & 17 & 18\end{array}$ $\begin{array}{lllllllllllllll}\text { JEF15 } & 88 & 32 & 56 & .32 & 1.3 & 50 & 43 & 32 & 24 & 1 & 66 & 1.4 & 12 & 16\end{array}$ $\begin{array}{lllllllllllllll}\text { JEF16 } & 64 & 38 & 26 & .38 & .55 & 48 & 47 & 34 & 18 & 1 & 59 & 1.4 & 17 & 19\end{array}$ $\begin{array}{lllllllllllllll}\text { JEF17 } & 96 & 34 & 62 & .32 & 1.0 & 54 & 61 & 27 & 12 & 0 & 72 & 1.5 & 10 & 15\end{array}$ $\begin{array}{lllllllllllllll}\text { JEF18 } & 97 & 38 & 59 & .14 & 1.3 & 46 & 46 & 26 & 26 & 2 & 114 & 1.5 & 11 & 12\end{array}$ $\begin{array}{lllllllllllllll}\text { JEF19 } & 68 & 38 & 37 & 1.2 & .77 & 75 & 48 & 40 & 12 & 0 & 70 & - & 15 & 8\end{array}$ 


$\begin{array}{lllllllllllllll}\text { JEF20 } & 67 & 30 & 37 & 1.2 & .77 & 76 & 48 & 41 & 11 & 0 & 115 & - & 14 & - \\ \text { JEF21 } & 65 & 40 & 25 & 1.3 & .83 & 72 & 30 & 47 & 22 & 1 & 102 & - & 15 & - \\ \text { JEF22 } & 98 & 43 & 55 & .18 & .92 & 53 & 60 & 25 & 14 & 1 & 109 & - & 12 & - \\ \text { JEF23 } & 91 & 39 & 52 & .29 & .73 & 54 & 71 & 19 & 10 & 0 & 96 & 1.4 & 11 & - \\ \text { JEF24 } & 92 & 34 & 58 & .47 & .88 & 61 & 66 & 20 & 13 & 1 & 78 & - & 11 & 15 \\ \text { JEF25 } & 88 & 40 & 48 & .38 & .81 & 57 & 59 & 21 & 18 & 2 & 59 & - & 12 & -\end{array}$


COLLOWASH EARTHFLOW SOIL PROPERTIES

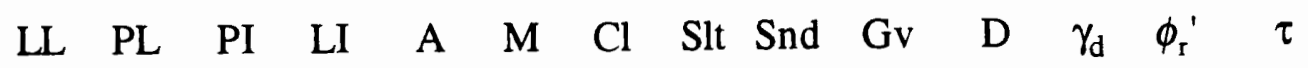
$\begin{array}{lllllllllllllll}\text { CEF1 } & 72 & 33 & 39 & .90 & .98 & 68 & 40 & 30 & 27 & 3 & 56 & - & 15 & -\end{array}$ $\begin{array}{lllllllllllllll}\text { CEF2 } & 78 & 36 & 42 & .35 & 1.1 & 51 & 40 & 29 & 27 & 4 & 97 & - & 15 & 6\end{array}$ $\begin{array}{lllllllllllllll}\text { CEF3 } & 75 & 37 & 38 & .09 & .74 & 41 & 51 & 25 & 23 & 1 & 115 & - & 14 & -\end{array}$ $\begin{array}{lllllllllllllll}\text { CEF4 } & 49 & 31 & 18 & .40 & 2.3 & 38 & 8 & 27 & 62 & 3 & 63 & - & 25 & 13\end{array}$ $\begin{array}{lllllllllllllll}\text { CEF5 } & 53 & 29 & 23 & .07 & 1.3 & 31 & 18 & 34 & 39 & 9 & 80 & - & 23 & 15\end{array}$ $\begin{array}{lllllllllllllll}\text { CEF6 } & 61 & 29 & 32 & .29 & 1.3 & 38 & 24 & 62 & 14 & 0 & 94 & - & 20 & 13\end{array}$ $\begin{array}{lllllllllllllll}\text { CEF7 } & 64 & 33 & 31 & .42 & .81 & 46 & 38 & 46 & 16 & 0 & 121 & - & 17 & 9\end{array}$ $\begin{array}{lllllllllllllll}\text { CEF8 } & 74 & 37 & 37 & .29 & .97 & 48 & 38 & 31 & 27 & 4 & 72 & 1.5 & 16 & -\end{array}$ $\begin{array}{lllllllllllllll}\text { CEF9 } & 72 & 36 & 36 & .58 & 1.0 & 57 & 35 & 33 & 29 & 3 & 81 & 1.5 & 18 & -\end{array}$ $\begin{array}{lllllllllllllll}\text { CEF10 } & 81 & 38 & 43 & .23 & 1.1 & 48 & 38 & 25 & 33 & 4 & 68 & - & 15 & -\end{array}$ $\begin{array}{lllllllllllllll}\text { CEF11 } & 78 & 36 & 42 & .21 & 1.7 & 45 & 25 & 62 & 13 & 0 & 49 & 1.4 & 17 & 10\end{array}$ $\begin{array}{lllllllllllllll}\text { CEF12 } & 72 & 37 & 35 & .66 & .73 & 60 & 48 & 35 & 17 & 0 & 67 & 1.4 & 16 & 8\end{array}$ $\begin{array}{lllllllllllllll}\text { CEF13 } & 54 & 30 & 24 & .71 & .73 & 47 & 33 & 36 & 25 & 6 & 108 & 1.4 & 19 & 15\end{array}$ $\begin{array}{lllllllllllllll}\text { CEF14 } & 70 & 34 & 36 & .72 & 1.0 & 60 & 35 & 37 & 26 & 2 & 123 & 1.5 & 17 & 10\end{array}$ $\begin{array}{lllllllllllllll}\text { CEF15 } & 58 & 37 & 21 & .33 & .70 & 44 & 30 & 40 & 17 & 13 & 101 & - & 21 & -\end{array}$ $\begin{array}{lllllllllllllll}\text { CEF16 } & 54 & 35 & 19 & .21 & .53 & 39 & 36 & 27 & 21 & 16 & 93 & - & 22 & 16\end{array}$ $\begin{array}{lllllllllllllll}\text { CEF17 } & 70 & 35 & 35 & .43 & 1.1 & 50 & 31 & 30 & 30 & 9 & 52 & - & 19 & -\end{array}$ $\begin{array}{lllllllllllllll}\text { CEF18 } & 77 & 34 & 43 & .51 & 1.4 & 56 & 30 & 28 & 35 & 7 & 83 & - & 17 & -\end{array}$ $\begin{array}{lllllllllllllll}\text { CEF19 } & 75 & 35 & 40 & .25 & 1.1 & 45 & 36 & 57 & 6 & 1 & 96 & 1.4 & 15 & 9\end{array}$ 
$\begin{array}{lllllllllllllll}\text { CEF20 } & 67 & 36 & 31 & .70 & .62 & 58 & 50 & 40 & 10 & 0 & 48 & 1.4 & 16 & 12\end{array}$ $\begin{array}{lllllllllllllll}\text { CEF21 } & 68 & 32 & 36 & .94 & .75 & 66 & 48 & 30 & 16 & 6 & 59 & 1.3 & 16 & \text { - }\end{array}$ $\begin{array}{lllllllllllllll}\text { CEF22 } & 72 & 31 & 41 & .29 & 1.4 & 43 & 29 & 54 & 17 & 0 & 95 & 1.4 & 15 & 12\end{array}$ $\begin{array}{lllllllllllllllll}\mathrm{CEF} 23 & 76 & 34 & 42 & .74 & .82 & 65 & 51 & 41 & 8 & 0 & 75 & - & 13 & -\end{array}$ $\begin{array}{llllllllllllllll}\text { CEF24 } & 79 & 38 & 41 & .51 & 1.7 & 59 & 24 & 43 & 27 & 6 & 56 & - & 17 & -\end{array}$ 


\section{ALDER EARTHFLOW DEPOSIT SOIL PROPERTIES}

$\begin{array}{llllllllllllll}L & \text { PL } & \text { PI } & \text { LI } & \text { A } & M & \text { Cl } & \text { Slt } & \text { Snd } & G v & D & \gamma_{d} & \phi_{r}{ }^{\prime} & \tau\end{array}$ $\begin{array}{lllllllllllllll}\mathrm{AEF1} & 57 & 45 & 12 & .17 & .52 & 47 & 23 & 26 & 44 & 7 & 70 & - & 25 & -\end{array}$ $\begin{array}{lllllllllllllll}\text { AEF2 } & 61 & 49 & 12 & .51 & .35 & 55 & 34 & 32 & 33 & 0 & 95 & - & 20 & -\end{array}$ $\begin{array}{lllllllllllllll}\mathrm{AEF} 3 & 55 & 39 & 16 & -.25 & .57 & 35 & 28 & 24 & 42 & 6 & 83 & - & 23 & -\end{array}$ $\begin{array}{lllllllllllllll}\mathrm{AEF} 4 & 57 & 41 & 15 & .15 & .50 & 43 & 30 & 32 & 35 & 3 & 70 & - & 20 & -\end{array}$ $\begin{array}{lllllllllllllll}\text { AEF5 } & 53 & 42 & 11 & .26 & 1.1 & 45 & 10 & 35 & 46 & 9 & 66 & - & 27 & -\end{array}$ $\begin{array}{lllllllllllllll}\text { AEF6 } & 48 & 40 & 8 & .39 & .67 & 43 & 12 & 29 & 34 & 25 & 75 & - & 26 & -\end{array}$ $\begin{array}{lllllllllllllll}\mathrm{AEF} 7 & 63 & 48 & 15 & .13 & .83 & 50 & 18 & 32 & 30 & 20 & 81 & 1.6 & 24 & 26\end{array}$ $\begin{array}{lllllllllllllll}\text { AEF8 } & 58 & 49 & 9 & -.97 & .35 & 40 & 26 & 35 & 21 & 18 & 101 & 1.7 & 23 & 35\end{array}$ $\begin{array}{lllllllllllllll}\text { AEF9 } & 69 & 55 & 14 & -.79 & .42 & 44 & 33 & 34 & 30 & 3 & 116 & 1.7 & 22 & -\end{array}$ $\begin{array}{lllllllllllllll}\mathrm{AEF} 10 & 70 & 54 & 16 & -.37 & 1.3 & 48 & 12 & 36 & 53 & 1 & 89 & 1.6 & 25 & -\end{array}$ $\begin{array}{lllllllllllllll}\text { AEF11 } & 65 & 55 & 10 & -.61 & .91 & 49 & 11 & 23 & 62 & 4 & 102 & 1.6 & 27 & -\end{array}$ $\begin{array}{lllllllllllllll}\text { AEF12 } & 62 & 50 & 12 & -.58 & .38 & 43 & 32 & 26 & 28 & 14 & 69 & - & 23 & -\end{array}$ $\begin{array}{lllllllllllllll}\text { AEF13 } & 54 & 49 & 5 & -1.6 & .36 & 41 & 14 & 32 & 44 & 10 & 81 & - & 27 & -\end{array}$ $\begin{array}{lllllllllllllll}\text { AEF14 } & 59 & 36 & 23 & .37 & .68 & 44 & 34 & 27 & 31 & 8 & 102 & - & 17 & -\end{array}$ $\begin{array}{lllllllllllllll}\text { AEF15 } & 60 & 42 & 18 & .33 & .64 & 48 & 28 & 40 & 30 & 2 & 67 & - & 22 & 42\end{array}$ $\begin{array}{lllllllllllllll}\text { AEF16 } & 62 & 45 & 17 & .41 & .52 & 52 & 33 & 34 & 33 & 0 & 84 & - & 18 & 49\end{array}$ $\begin{array}{lllllllllllllll}\text { AEF17 } & 66 & 54 & 12 & -.51 & .63 & 48 & 49 & 25 & 45 & 3 & 118 & - & 25 & 62\end{array}$ $\begin{array}{lllllllllllllll}\text { AEF18 } & 63 & 46 & 17 & .29 & 1.4 & 51 & 12 & 27 & 54 & 7 & 60 & 1.7 & 24 & 40\end{array}$ $\begin{array}{lllllllllllllll}\text { AEF19 } & 77 & 71 & 6 & -2.8 & .15 & 54 & 40 & 33 & 26 & 0 & 78 & 1.7 & 22 & 45\end{array}$ $\begin{array}{lllllllllllllll}\text { AEF20 } & \text { NP } & \text { NP } & \text { N/A } & \text { N/A } & \text { N/A } & 52 & 14 & 46 & 39 & 1 & 95 & 1.7 & 25 & 38\end{array}$ 
$\begin{array}{lllllllllllllll}\text { AEF21 } & 66 & 61 & 5 & -1.9 & .09 & 52 & 53 & 17 & 28 & 2 & 105 & 1.8 & 21 & 50\end{array}$ $\begin{array}{lllllllllllllll}\text { AEF22 } & 73 & 58 & 21 & .43 & .29 & 67 & 73 & 13 & 13 & 1 & 135 & - & 15 & -\end{array}$ $\begin{array}{lllllllllllllllll}\text { AEF23 } & 72 & 47 & 25 & .44 & .40 & 58 & 63 & 5 & 31 & 1 & 97 & - & 14 & -\end{array}$ $\begin{array}{llllllllllllllll}\text { AEF2 } & 79 & 51 & 28 & .29 & 1.1 & 59 & 25 & 62 & 13 & 0 & 106 & - & 17 & 35\end{array}$ $\begin{array}{lllllllllllllll}\text { AEF25 } & 50 & 42 & 8 & .25 & .53 & 44 & 15 & 31 & 48 & 6 & 68 & - & 25 & -\end{array}$ $\begin{array}{llllllllllllllll}\text { AEF26 } & 76 & 50 & 26 & .19 & .74 & 55 & 35 & 56 & 9 & 0 & 111 & - & 17 & -\end{array}$ $\begin{array}{lllllllllllllllll}\text { AEF27 } & 46 & 39 & 7 & .57 & .64 & 43 & 11 & 13 & 71 & 5 & 79 & - & 29 & -\end{array}$ $\begin{array}{lllllllllllllll}\text { AEF28 } & 62 & 40 & 22 & .55 & .55 & 52 & 40 & 38 & 21 & 1 & 90 & 1.7 & 18 & 11\end{array}$ 


\section{HAPPY CREEK EARTHFLOW DEPOSIT SOIL PROPERTIES}

$\begin{array}{llllllllllllll}L & \text { PL } & \text { PI } & \text { LI } & \text { A } & \text { M } & \mathrm{Cl} & \text { Slt } & \text { Snd } & \mathrm{Gv} & \mathrm{D} & \gamma_{\mathrm{d}} & \phi_{\mathrm{r}}{ }^{\prime} & \tau\end{array}$ $\begin{array}{lllllllllllllll}\text { HCEF1 } & 48 & 40 & 8 & .63 & 1.1 & 45 & 3 & 31 & 66 & 0 & 55 & - & 28 & 60\end{array}$ $\begin{array}{lllllllllllllll}\text { HCEF2 } & 63 & 38 & 25 & -.04 & .66 & 37 & 32 & 42 & 26 & 0 & 78 & - & 17 & -\end{array}$ $\begin{array}{lllllllllllllll}\text { HCEF3 } & 40 & 38 & 2 & -3.5 & 1.0 & 31 & 2 & 12 & 86 & 0 & 63 & 1.7 & 36 & 30\end{array}$ $\begin{array}{lllllllllllllll}\text { HCEF4 } & \text { NP } & \text { NP } & \text { N/A } & \text { N/A } & \text { N/A } & 32 & 8 & 27 & 53 & 12 & 51 & 1.8 & 30 & 45\end{array}$ $\begin{array}{lllllllllllllll}\text { HCEF5 } & 47 & 43 & 4 & .75 & .27 & 46 & 8 & 33 & 52 & 7 & 46 & 1.8 & 32 & -\end{array}$ $\begin{array}{lllllllllllllll}\text { HCEF6 } & 40 & 39 & 1 & 1 & .07 & 40 & 8 & 36 & 53 & 3 & 84 & - & 33 & -\end{array}$ $\begin{array}{lllllllllllllll}\text { HCEF7 } & \text { NP } & \text { NP } & \text { N/A } & \text { N/A } & \text { N/A } & 31 & 3 & 24 & 53 & 20 & 79 & - & 33 & 70\end{array}$ $\begin{array}{lllllllllllllll}\text { HCEF8 } & 43 & 38 & 5 & 1.2 & .29 & 44 & 17 & 25 & 49 & 9 & 87 & - & 32 & -\end{array}$ 
NON-EARTHFLOW LANDFORM SOIL PROPERTIES

$\begin{array}{llllllllllllll}L L & \text { PL } & \text { PI } & \text { LI } & \text { A } & \text { M } & \text { Cl } & \text { Slt } & \text { Snd } & \text { Gv } & \text { D } & \gamma_{d} & \phi_{r}^{\prime} & \tau\end{array}$ $\begin{array}{lllllllllllllll}\text { TER1 } & 47 & 31 & 69 & 1.0 & .94 & 47 & 6 & 38 & 50 & 5 & 79 & - & 27 & -\end{array}$ $\begin{array}{lllllllllllllll}\text { TER2 } & 43 & 32 & 30 & .36 & 1.22 & 36 & 9 & 30 & 43 & 18 & 70 & - & 26 & 55\end{array}$ $\begin{array}{lllllllllllllll}\text { TER3 } & 48 & 36 & 68 & -.25 & 1.09 & 33 & 11 & 41 & 40 & 8 & 87 & 1.7 & 25 & 50\end{array}$ $\begin{array}{lllllllllllllll}\text { BAS1 } & \mathrm{NP} & \mathrm{NP} & \mathrm{N} / \mathrm{A} & \mathrm{N} / \mathrm{A} & \mathrm{N} / \mathrm{A} & 36 & 8 & 18 & 61 & 13 & 43 & - & 31 & 60\end{array}$ $\begin{array}{lllllllllllllll}\text { BAS2 } & \mathrm{NP} & \mathrm{NP} & \mathrm{N} / \mathrm{A} & \mathrm{N} / \mathrm{A} & \mathrm{N} / \mathrm{A} & 34 & 6 & 21 & 55 & 18 & 61 & 1.8 & 32 & -\end{array}$ $\begin{array}{lllllllllllllll}\text { BAS3 } & N P & N P & \text { N/A } & \text { N/A } & \text { N/A } & 38 & 5 & 18 & 57 & 20 & 85 & 1.8 & 34 & -\end{array}$ $\begin{array}{lllllllllllllll}\text { TILL1 NP } & \text { NP } & \text { N/A } & \text { N/A } & \text { N/A } & 36 & 4 & 18 & 44 & 34 & 57 & 1.8 & 31 & -\end{array}$ $\begin{array}{lllllllllllllll}\text { TILL2 } & \text { NP } & \text { NP } & \text { N/A } & \text { N/A } & \text { N/A } & 33 & 1 & 15 & 50 & 34 & 63 & 1.7 & 34 & -\end{array}$ $\begin{array}{lllllllllllllll}\text { TILL3 } & \text { NP } & \text { NP } & \text { N/A } & \text { N/A } & \text { N/A } & 37 & 5 & 35 & 44 & 16 & 76 & 1.8 & 33 & 65\end{array}$ $\begin{array}{lllllllllllllll}\text { TILLA } & \text { NP } & \text { NP } & \text { N/A } & \text { N/A } & \text { N/A } & 33 & 0 & 9 & 57 & 34 & 95 & 1.8 & 35 & -\end{array}$ $\begin{array}{lllllllllllllll}\text { TILL5 } & \text { NP } & \text { NP } & \text { N/A } & \text { N/A } & \text { N/A } & 36 & 4 & 7 & 49 & 40 & 82 & 1.8 & 37 & 75\end{array}$ 
APPENDIX B

MEAN SOIL PROPERTIES FOR EACH LANDFORM 
JUNCTION EARTHFLOW

(Active)

Property

Liquid Limit

Plastic Limit

Plasticity Index

Liquidity Index

Field Moisture (\%)

Activity

Clay $\%$

Silt \%

Sand $\%$

Gravel \%

Unified Classification

Sample Depth $(\mathrm{cm})$

Dry Unit Wt. $\left(\gamma_{\mathrm{d}}\right)(\mathrm{g} / \mathrm{cc}) \quad 10 \quad 1.47$

Friction Angle $\left(\phi_{\mathrm{r}}{ }^{\prime}\right) \quad 25 \quad 13$

Shear Strength $(\tau)(\mathrm{kPa}) \quad 14 \quad 15$

$25 \quad 87$

$25 \quad 40$
N Mean Minimum Maximum Range S.D. C.V.

64

118

54

$15 \quad 18$
30

58

83

1.30

0.14

46

90

0.44

2.18

22

19

80

47

36

6

$\mathrm{CH}$

137

1.54

17

21

28

$6 \quad 16$

$58 \quad 16 \quad 33$

$\begin{array}{lll}1.16 & 0.37 & 69\end{array}$

$\begin{array}{lll}44 & 11 & 18\end{array}$

$\begin{array}{lll}1.74 & 0.34 & 37\end{array}$

$\begin{array}{lll}58 & 13 & 24\end{array}$

$\begin{array}{lll}28 & 9 & 30\end{array}$

$\begin{array}{lll}35 & 7 & 42\end{array}$

$\begin{array}{lll}6 & 1 & 164\end{array}$ N/A N/A N/A $\begin{array}{lll}85 & 22 & 27\end{array}$

1.40

8

7
0.14

$92.6 \quad 20$

$\begin{array}{lll}14 & 3.8 & 25\end{array}$

$\mathrm{N}=$ number of observations; S.D. $=$ standard deviation; C.V. $=$ coefficient of variation 
COLLOWASH EARTHFLOW

(Active)

$\begin{array}{lrrrrrrr}\text { Property } & \underline{\mathrm{N}} & \underline{\text { Mean }} & \text { Minimum } & \text { Maximum } & \text { Range } & \underline{\text { S. D. }} & \text { C. V. } \\ \text { Liquid Limit } & 24 & 69 & 49 & 81 & 32 & 9 & 13 \\ \text { Plastic Limit } & 24 & 34 & 29 & 38 & 9 & 3 & 8 \\ \text { Plasticity Index } & 24 & 35 & 18 & 43 & 25 & 8 & 23 \\ \text { Liquidity Index } & 24 & 0.45 & 0.07 & 0.94 & 0.87 & 0.2 & 54 \\ \text { Field Moisture }(\%) & 24 & 50 & 31 & 68 & 37 & 10 & 20 \\ \text { Activity } & 24 & 1.08 & 0.53 & 2.25 & 1.72 & 0.4 & 37 \\ \text { Clay \% } & 24 & 35 & 8 & 51 & 43 & 11 & 31 \\ \text { Silt \% } & 24 & 37 & 25 & 62 & 37 & 11 & 30 \\ \text { Sand \% } & 24 & 24 & 6 & 62 & 56 & 12 & 50 \\ \text { Gravel \% } & 24 & 4 & 0 & 16 & 16 & 4 & 107 \\ \text { Unified Classification } & 24 & \mathrm{CH} & \mathrm{ML} & \mathrm{CH} & \mathrm{N} / \mathrm{A} & \mathrm{N} / \mathrm{A} & \mathrm{N} / \mathrm{A} \\ \text { Sample Depth }(\mathrm{cm}) & 24 & 81 & 48 & 123 & 75 & 23 & 28 \\ \text { Dry Unit Wt. }\left(\gamma_{\mathrm{d}}\right)(\mathrm{g} / \mathrm{cc}) & 10 & 1.42 & 1.34 & 1.51 & 0.17 & 0.1 & 4 \\ \text { Friction Angle }\left(\phi_{\mathrm{r}}{ }^{\prime}\right) & 24 & 17 & 13 & 25 & 12 & 3 & 17 \\ \text { Shear Strength }(\tau)(\mathrm{kPa}) & 13 & 11 & 6 & 16 & 10 & 3 & 26\end{array}$

$\mathrm{N}=$ number of observations; S.D. = standard deviation; C.V. = coefficient of variation 
ALDER EARTHFLOW DEPOSIT

Property

Liquid Limit

Plastic Limit

Plasticity Index

Liquidity Index

Field Moisture (\%)

Activity

Clay \%

Silt \%

Sand $\%$

Gravel \%

Unified Classification

Sample Depth $(\mathrm{cm})$

Dry Unit Wt. $\left(\gamma_{\mathrm{d}}\right)(\mathrm{g} / \mathrm{cc}) \quad 10 \quad 1.68$

Friction Angle $\left(\phi_{\mathrm{r}}{ }^{\prime}\right) \quad 28 \quad 22$

Shear Strength $(\tau)(\mathrm{kPa}) \quad 11 \quad 39$
N Mean

$27 \quad 62$

$27 \quad 48$

$27 \quad 14$

$\begin{array}{ll}27 & -0.17\end{array}$

$28 \quad 46$

$27 \quad 0.53$

$28 \quad 28$

$28 \quad 31$

$28 \quad 35$

$28 \quad 6$

$28 \mathrm{MH}$

$28 \quad 89$
ML

60

1.60

14

11

46

36

5

$-2.81$

31

0.07

2

5

9

0

25

MH

135

1.81

29

62
Range S.D. C.V.

$\begin{array}{lll}33 & 9 & 14\end{array}$

$\begin{array}{lll}35 & 8 & 16\end{array}$

$\begin{array}{lll}23 & 7 & 45\end{array}$

$\begin{array}{lll}3.38 & 0.8 & -489\end{array}$

$\begin{array}{lll}36 & 8 & 17\end{array}$

$\begin{array}{lll}1.07 & 0.3 & 53\end{array}$

$\begin{array}{lll}68 & 17 & 60\end{array}$

$\begin{array}{lll}57 & 12 & 38\end{array}$

$\begin{array}{lll}62 & 15 & 41\end{array}$

$\begin{array}{lll}25 & 7 & 114\end{array}$

N/A N/A N/A

$\begin{array}{lll}75 & 19 & 21\end{array}$

$0.21 \quad 0.1 \quad 3.4$

$\begin{array}{lll}15 & 4 & 18\end{array}$

$\begin{array}{lll}51 & 13 & 34\end{array}$

$\mathrm{N}=$ number of observations; S.D. $=$ standard deviation; C.V. = coefficient of variation 


\section{HAPPY CREEK EARTHFLOW DEPOSIT}

Property

Liquid Limit

Plastic Limit

Plasticity Index

Liquidity Index

Field Moisture (\%)

Activity

Clay \%

Silt \%

Sand \%

Gravel \%

$\begin{array}{lll}\text { Unified Classification } & 8 & \mathrm{MH}\end{array}$

Dry Unit Wt. $\left(\gamma_{\mathrm{d}}\right)(\mathrm{g} / \mathrm{cc}) \quad 3 \quad 1.75$

Friction Angle $\left(\phi_{\mathrm{r}}^{\prime}\right) \quad 8 \quad 30$

Shear Strength $(\tau)(\mathrm{kPa}) \quad 4 \quad 51$

$8 \quad 68$

N Mean

$6 \quad 47$

$6 \quad 39$

$6 \quad 8$

$6 \quad 0.01$

$8 \quad 38$

$\begin{array}{ll}6 & 0.57\end{array}$

$8 \quad 10$

$8 \quad 29$

$8 \quad 55$

6

0

ML

46

1.68

17

30
Range S.D. C.V.

$\begin{array}{lll}23 & 9 & 18\end{array}$

43

25

1.20

46

1.14

32

42

86

20

MH

87

1.81

0.13

36

19

70

$4.7 \quad 1.3$

$15 \quad 6$

17

$\begin{array}{lll}1.07 & 0.4 & 76\end{array}$

$\begin{array}{lll}30 & 10 & 99\end{array}$

$\begin{array}{lll}30 & 9 & 31\end{array}$

$\begin{array}{lll}60 & 17 & 31\end{array}$

$\begin{array}{lll}20 & 7 & 112\end{array}$

N/A N/A N/A

$41 \quad 16 \quad 24$

Sample Depth (cm)

$\mathrm{N}=$ number of observations; S.D. $=$ standard deviation; C.V. = coefficient of variation 
NON-EARTHFLOW LANDFORMS

(till, basalt, alluvial terrace)

Property

Liquid Limit

Plastic Limit

Plasticity Index

Liquidity Index

Field Moisture (\%)

Activity

Clay $\%$

Silt $\%$

Sand $\%$

Gravel \%

Unified Classification

Sample Depth $(\mathrm{cm})$

$11 \quad 73$

Dry Unit Wt. $\left(\gamma_{\mathrm{d}}\right)(\mathrm{g} / \mathrm{cc})$

Friction Angle $\left(\phi_{\mathrm{r}}^{\prime}\right)$

$11 \quad 31$

Shear Strength $(\tau)(\mathrm{kPa}) \quad 5 \quad 61$

Smectite as \% of Clay 11

$\mathrm{N}=$ number of observations; S.D. = standard deviation;

346

$3 \quad 33$

$3 \quad 13$

$\begin{array}{lll}3 & 0.37 & -0.25\end{array}$

33

0.94

GW

43

1.70

25
N Mean Minimum Maximum Range S. D. C.V.

48

5

36

36

$\begin{array}{lll}5 & 3 & 8\end{array}$

16

$\begin{array}{lll}5 & 3 & 20\end{array}$

1.00

1.25

$0.6 \quad 169$

47

14

$4 \quad 11$

1.22

0.28

$0.14 \quad 13$

11

11

$3 \quad 60$

41

$\begin{array}{lll}34 & 11 & 49\end{array}$

61

21

$\begin{array}{ll}7 & 14\end{array}$

40

40

$13 \quad 59$

MH

N/A N/A N/A

95

52

$15 \quad 21$

1.84

0.14

0.1

3

37

12

4

12

$50 \quad 75$

$\begin{array}{lll}25 & 10 & 16\end{array}$

23

23

$10 \quad 172$

C.V. = coefficient of variation 
APPENDIX C

CORRELATION MATRIX FOR EACH LANDFORM 


\section{JUNCTION EARTHFLOW CORRELATION MATRIX}

$\begin{array}{llllllllllllll} & \text { PL } & \text { PI } & \text { LI } & \text { A } & \text { M } & \text { Cl } & \text { Slt } & \text { Snd } & \text { Gv } & D & \gamma_{d} & \phi_{r}{ }^{\prime} & \tau\end{array}$

$\begin{array}{lccccccccccccccccc}\mathrm{LL} & 1.0 & - & - & - & - & - & - & - & - & - & - & - & - & - \\ \mathrm{PL} & .15 & 1.0 & - & - & - & - & - & - & - & - & - & - & - & - \\ \mathrm{PI} & .92^{*} & -.26 & 1.0 & - & - & - & - & - & - & - & - & - & - & - \\ \mathrm{LI} & -.67^{*} & -.10 & -.61^{*} & 1.0 & - & - & - & - & - & - & - & - & - & - \\ \text { Activity } & .42^{\dagger} & -.24 & .51^{*} & -.44 & 1.0 & - & - & - & - & - & - & - & - & - \\ \text { Moisture } & -.17 & .29 & -.28 & .78^{*} & -.32 & 1.0 & - & - & - & - & - & - & - & - \\ \text { Clay } & .54^{*} & -.13 & .58^{*} & -.32 & -.34 & -.11 & 1.0 & - & - & - & - & - & - & - \\ \text { Silt } & -.49^{\dagger} & .18 & -.55^{*} & .58^{*} & .04 & .48^{\dagger} & -.76 & 1.0 & - & - & - & - & - & - \\ \text { Sand } & -.32 & .04 & -.33 & -.10 & .44^{\dagger} & -.30 & -.74 & .12 & 1.0 & - & - & - & - & - \\ \text { Gravel } & -.19 & -.15 & -.12 & -.24 & .54^{*} & -.43^{\dagger} & -.45 & -.08 & .69 & 1.0 & - & - & - & - \\ \text { Depth } & .22 & -.05 & .23 & .00 & .12 & .05 & .15 & .00 & -.26 & .06 & 1.0 & - & - & - \\ \gamma_{\mathrm{d}} & .40 & .73 & -.06 & .47 & -.04 & .70^{\dagger} & -.16 & .45 & -.31 & -.48 & . .02 & 1.0 & - & - \\ \phi_{\mathrm{r}}{ }^{\prime} & -.86^{*} & .20 & -.92^{*} & .51^{*} & -.30 & .21 & . .64^{*} & .51^{*} & .43^{\dagger} & .31 & -.24 & .10 & 1.0 & - \\ \tau & .08 & .07 & .07 & -.69^{*} & .27 & . .64^{\dagger} & -.02 & -.38 & .25 & .48 & .09 & . .48 & .09 & 1.0\end{array}$

Textural classes are not statistically significant because they represent percentages of a constant whole. *Significant at the 1 percent level. ${ }^{\dagger}$ Significant at the 5 percent level. 


\section{COLLOWASH EARTHFLOW CORRELATION MATRIX}

$\begin{array}{llllllllllllll}\text { LL } & \text { PL } & \text { PI } & \text { LI } & \text { A } & \text { M } & \text { Cl } & \text { Slt } & \text { Snd } & \text { Gv } & \text { D } & \gamma_{d} & \phi_{\mathrm{r}}{ }^{\prime} & \tau\end{array}$ $\mathrm{LL} \quad 1.0-\quad-\quad-\quad-\quad--$ $\mathrm{PL} \quad .62^{*} 1.0 \quad-\quad-\quad--$ - - - PI $\quad .96^{*} \quad .39 \quad 1.0 \quad-\quad-\quad-\quad-\quad-\quad-$ LI $\quad \begin{array}{llllllll}.08 & .09 & .13 & 1.0 & - & - & - & -\end{array}-$ $\begin{array}{llllllllllll}\text { Activity } & .02 & -.21 & .10 & -.26 & 1.0 & - & - & - & - & - & -\end{array}$ $\begin{array}{lllllllllllll}\text { Moisture } & .52^{*} & .30 & .51^{\dagger} & .87^{*} & -.26 & 1.0 & - & - & - & - & -\end{array}$ $\begin{array}{lllllllllllll} & \text { Clay } & .45^{\prime} & .42^{\prime} & .39 & .40 & -.80^{*} & .57^{*} & 1.0 & - & - & - & -\end{array}$ Silt $\quad \begin{array}{lllllllllllllll}.08 & -.22 & .17 & -.17 & .22 & -.19 & -.22 & 1.0 & - & - & - & -\end{array}$ Sand $\quad \begin{array}{lllllllllllllll}.32 & -.18 & -.32 & -.14 & .57^{*} & -.25 & -.60 & -.59 & 1.0 & - & - & - & -\end{array}$ $\begin{array}{lllllllllllllll}\text { Gravel } & -.43^{\dagger} & .05 & -.52^{*} & -.17 & .18 & -.23 & -.25 & -.45 & .28 & 1.0 & - & - & -\end{array}$ Depth $\quad \begin{array}{lllllllllllll}.21 & -.20 & -.18 & -.25 & -.31 & -.34 & .06 & .08 & -.13 & .01 & 1.0 & - & -\end{array}$

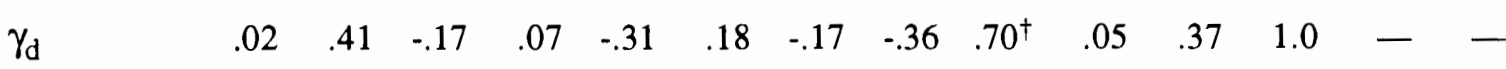
$\begin{array}{lllllllllllllll}\phi_{\mathrm{r}}{ }^{\prime} & -.85^{*} & -.42^{\dagger} & -.86^{*} & -.28 & .33 & -.59^{*} & -.75^{*} & -.10 & .56^{*} & .56^{*} & .00 & .55 & 1.0 & -\end{array}$ $\begin{array}{lllllllllllllll}\tau & -.82^{*} & -.62^{\dagger} & -.77^{*} & -.19 & .02 & -.59^{\dagger} & -.44 & -.17 & .30 & .61^{\dagger} & -.06 & -.14 & .72^{*} & 1.0\end{array}$ Textural classes are not statistically significant because they represent percentages of a constant whole. *Significant at the 1 percent level. `Significant at the 5 percent level. 


\section{ALDER EARTHFLOW DEPOSIT CORRELATION MATRIX}

$\begin{array}{llllllllllllll}L & \text { PL } & \text { PI } & \text { LI } & \text { A } & \text { M } & \mathrm{Cl} & \text { Slt } & \text { Snd } & \text { Gv } & \text { D } & \gamma_{d} & \phi_{r}{ }^{\prime} & \tau\end{array}$

$\begin{array}{lccccccccccccccccc}\text { LL } & 1.0 & - & - & - & - & - & - & - & - & - & - & - & - & - \\ \text { PL } & .70^{*} & 1.0 & - & - & - & - & - & - & - & - & - & - & - & - \\ \text { PI } & .53^{*} & -.22 & 1.0 & - & - & - & - & - & - & - & - & - & - & - \\ \text { LI } & -.26 & -.73^{*} & .56^{*} & 1.0 & - & - & - & - & - & - & - & - & - & - \\ \text { Activity } & .02 & -.27 & .33 & .41^{\dagger} & 1.0 & - & - & - & - & - & - & - & - & - \\ \text { Moisture } & .72^{*} & .47^{\dagger} & .50^{*} & .15 & -.04 & 1.0 & - & - & - & - & - & - & - & - \\ \text { Clay } & .53^{*} & .34 & .39^{\dagger} & -.06 & .60^{*} & .58^{*} & 1.0 & - & - & - & - & - & - & - \\ \text { Silt } & .28 & -.01 & .33 & .04 & .35 & .06 & -.33 & 1.0 & - & - & - & - & - & - \\ \text { Sand } & -.56^{*} & -.24 & -.50^{*} & .05 & .37 & -.46^{\dagger} & -.65 & -.39 & 1.0 & - & - & - & - & - \\ \text { Gravel } & . .53^{*} & -.29 & -.38 & -.01 & .04 & -.52^{*} & -.38 & -.12 & .07 & 1.0 & - & - & - & - \\ \text { Depth } & .57^{*} & .43^{\dagger} & .33 & . .09 & -.24 & .48^{*} & .51^{*} & -.01 & -.43^{\dagger} & -.34 & 1.0 & - & - & - \\ \gamma_{d} & .04 & .23 & -.32 & -.41 & -.59 & .38 & .81^{*} & -.25 & -.55 & -.27 & .03 & 1.0 & - & - \\ \phi_{\mathrm{r}}{ }^{\prime} & -.61^{*} & -.09 & -.77^{*} & -.23 & .25 & -.62^{*} & -.83^{*} & -.07 & .76^{*} & .43^{\dagger} & . .47^{\dagger} & . .68^{\dagger} & 1.0 & - \\ \tau & .16 & .48 & -.47 & -.39 & -.20 & -.07 & .00 & -.39 & .45 & -.28 & .25 & .40 & .31 & 1.0\end{array}$

Textural classes are not statistically significant because they represent percentages of a constant whole. * Significant at the 1 percent level. †Significant at the 5 percent level. 
HAPPY CREEK EARTHFLOW DEPOSIT CORRELATION MATRIX

$\begin{array}{llllllllllllll}L & \text { PL } & \text { PI } & \text { LI } & \text { A } & \text { M } & \text { Cl } & \text { Sit } & \text { Snd } & \text { Gv } & \text { D } & \gamma_{\mathrm{d}} & \phi_{\mathrm{r}}{ }^{\prime} & \tau\end{array}$ $\mathrm{L} \quad 1.0-\mathrm{L}_{-} \quad-\mathrm{C}_{-}-$ PL $\quad-.04 \quad 1.0 \quad-\quad-\quad-\quad-\quad-\quad-\quad-\quad-$ PI $\quad .98^{*} \quad-.26 \quad 1.0 \quad-\quad-\quad-\quad-\quad-\quad-\quad-$ $\begin{array}{llllllllll}\text { LI } & & .17 & .34 & .09 & 1.0 & - & - & - & -\end{array}-$ $\begin{array}{llllllllllllllll}\text { Activity } & .19 & -.21 & .23 & -.58 & 1.0 & - & - & - & - & - & - & - & -\end{array}$ $\begin{array}{llllllllllllll}\text { Moisture } & .02 & .64 & -.12 & .87^{\dagger} & -.34 & 1.0 & - & - & - & - & - & - & -\end{array}$ $\begin{array}{llllllllllllllll}\text { Clay } & & .80 & -.35 & .85^{\dagger} & .28 & . .24 & .15 & 1.0 & - & - & - & - & - & -\end{array}$ $\begin{array}{lllllllllllllllll}\text { Silt } & & & .66 & .24 & .59 & .71 & -.38 & .47 & .63 & 1.0 & - & - & - & - & -\end{array}$ $\begin{array}{lllllllllllllll}\text { Sand } & -.74 & .01 & -.72 & -.64 & .48 & .20 & -.83 & -.82 & 1.0 & - & - & - & - & -\end{array}$ $\begin{array}{llllllllllllll}\text { Gravel } & -.31 & .32 & -.38 & .54 & -.72 & -.34 & -.25 & -.22 & -.16 & 1.0 & - & - & -\end{array}$ $\begin{array}{lllllllllllllll}\text { Depth } & & -.01 & -.77 & .16 & .21 & -.43 & -.10 & .40 & .11 & -.35 & .11 & 1.0 & - & -\end{array}$ $\gamma_{\mathrm{d}}$ $\phi_{\mathrm{r}}{ }^{\prime} \quad-\quad-.97^{*} \quad \begin{array}{lllllllllllllll} & .18 & -.98^{*} & -.25 & -.16 & -.12 & -.83^{\dagger} & -.73^{\prime \dagger} & .75^{\dagger} & .33 & -.09 & * * & 1.0 & -\end{array}$ $\tau$

$\begin{array}{llllllllllllll}* * & * * & * * & * * & * * & .32 & -.07 & .69 & -.72 & .58 & .47 & * * & -.48 & 1.0\end{array}$ Textural classes are not statistically significant because they represent percentages of a constant whole. *Significant at the 1 percent level. †Significant at the 5 percent level. **Not enough samples for valid test. 


\section{NON-EARTHFLOW LANDFORMS CORRELATION MATRIX}

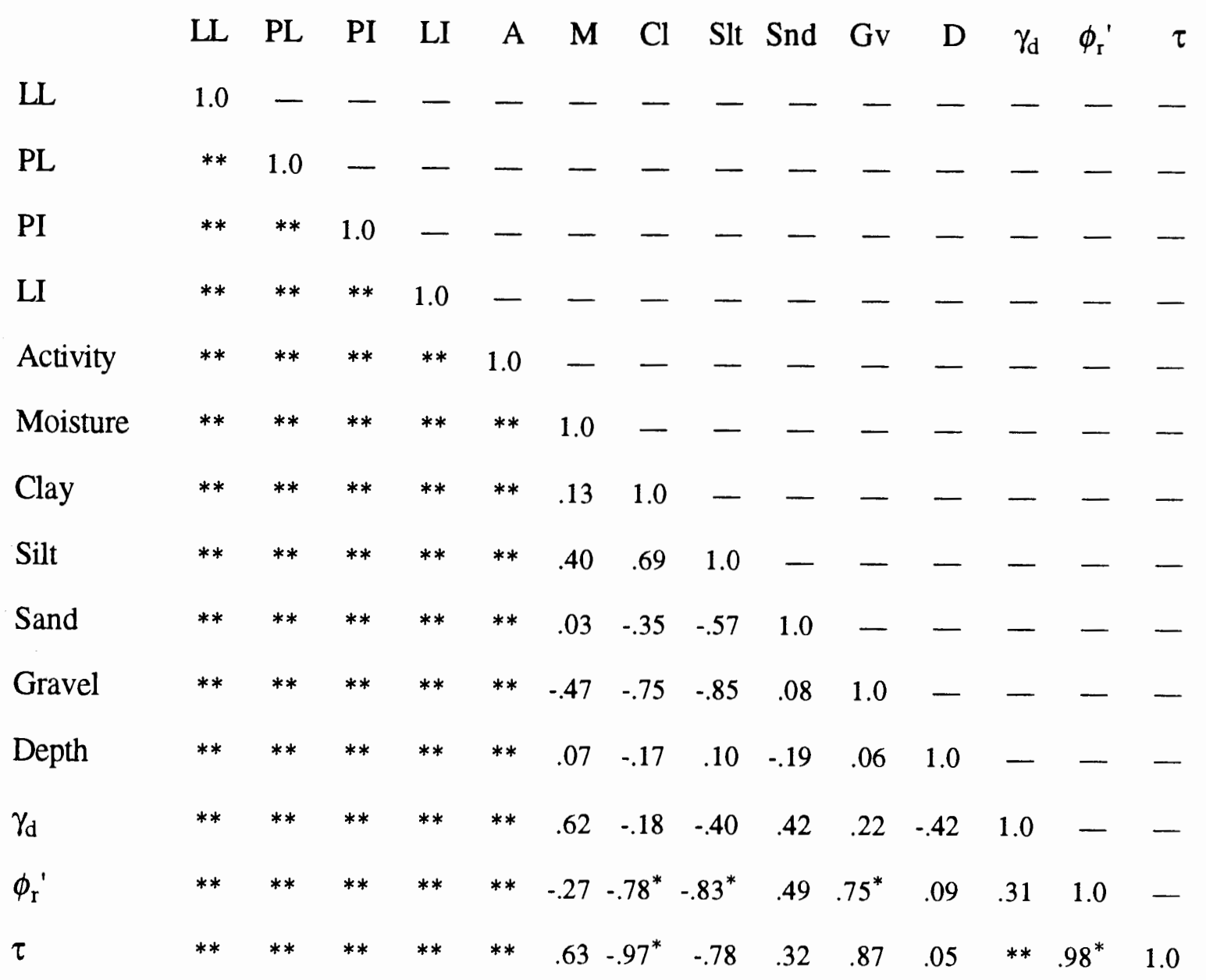

Textural classes are not statistically significant because they represent percentages of a constant whole. *Significant at the 1 percent level. †Significant at the 5 percent level. **Not enough samples for valid test. 